\title{
State of the Art in the Control of Inclusions during Steel Ingot Casting
}

\author{
LIFENG ZHANG and BRIAN G. THOMAS
}

\begin{abstract}
This article extensively reviews published research on inclusions in ingot steel and defects on ingot products, methods to measure and detect inclusions in steel, the causes of exogenous inclusions, and the transport and entrapment of inclusions during fluid flow, segregation, and solidification of steel cast in ingot molds. Exogenous inclusions in ingots originate mainly from reoxidation of the molten steel, slag entrapment, and lining erosion, which are detailed in this article. The measures to prevent the formation of exogenous inclusions and improve their removal are provided, which are very useful for the clean steel production of ingot industries.
\end{abstract}

\section{INTRODUCTION}

Although the percentage of steel produced in the world via ingot casting has decreased to 11.2 pct (Figure $1^{[1]}$ ) in 2003, some low-alloy steel grades and steel for special applications can only be produced by this process. These include high carbon chromium bearing steel ${ }^{[2]}$ thick plate, seamless tube, forgings, bars, and wire rods. ${ }^{[3]}$ Thus, the production of crude steel ingots in 2003 was about 2.5 million metric tonnes in United States, 17.8 million metric tonnes in China, and 108.7 million metric tonnes in the world, which is still important.

Top pouring is easy to use, but generates many defects both on the surface and internally, which is not suitable for high-quality steels. Bottom pouring is better, especially for intensive deoxidation, high superheat, low-speed casting, and casting in a nonoxidizing atmosphere. The typical process from steelmaking to steel refining to bottom-poured ingot casting is given in Figure $2 .^{[4,5]}$ During teeming, molten steel flows through the well and controlling side gate at the bottom of the ladle, enters the trumpet (also called the central runner) and passes through the spider, into the runners. The system is often flooded with inert gas (such as argon) to lessen oxidation. Molten steel then enters the ingot mold through an upward-facing ingate near the end of the runner. The rising steel level burns through suspended bags to release mold powder. Then, the powder spreads and melts to form a slag layer, floating on top of the molten steel. The slag layer protects the molten steel from atmospheric oxidation and absorbs inclusions from the moltent steel. After teeming, the ingot stands to solidify for the optimal time for easy removal (stripping) from the mold.

The ever-increasing demands for high quality have made the steelmaker increasingly aware of the necessity for products to meet stringent "cleanliness" requirements. Nonmetallic inclusions are a significant problem in cast steels because they may lead to problems in castings that require expensive casting repairs or rejection. The mechanical properties of steel are controlled to a large degree by the

LIFENG ZHANG, Professor, is with the Department of Materials Science and Engineering Norwegian University of Science and Technology (NTNU), 7491 Trondheim, Norway. Contact e-mail: lifeng.zhang@material. ntnu.no BRIAN G. THOMAS, Professor, is with the Department of Mechanical and Industrial Engineering, University of Illinois at UrbanaChampaign, Urbana, IL 61801.

Manuscript submitted August 22, 2005. volume fraction, size, distribution, composition, and morphology of inclusions and precipitates, which act as stress raisers. For example, ductility is appreciably decreased with increasing amounts of either oxides or sulfides. ${ }^{[6]}$ Fracture toughness decreases when inclusions are present, especially in higher-strength lower-ductility alloys. Similar pronounced property degradation caused by inclusions is observed in tests that reflect slow, rapid, or cyclic strain rates, such as creep, impact, and fatigue testing. ${ }^{[6]}$ Figure 3 shows that inclusions cause voids, which will induce cracks if larger than a critical value. ${ }^{[7]}$ Large exogenous inclusions also cause inferior surface appearance, poor polishability, reduced resistance to corrosion, and, in severe cases, slag lines and laminations. ${ }^{[8]}$ Inclusions also lower resistance to hydrogen-induced cracks. ${ }^{[9]}$ The source of most fatigue problems in steel are hard and brittle oxide inclusions. Larger inclusions have a more negative effect on the fatigue life than smaller ones. ${ }^{[2]}$ In general, rolling contact fatigue life decreases as the total oxygen content increases. ${ }^{[2]}$ Figure 4 shows the fatigue limit for different inclusion sizes in different strength steels. ${ }^{[10]}$

To avoid these problems, the size and frequency of detrimental inclusions must be carefully controlled. It is especially important to ensure that there are no inclusions in the casting above a critical size. Table I shows some typical restrictions on inclusions in different steels, where T.O. means the total oxygen in the steel. ${ }^{[11]}$ The life of bearing steels greatly depends on controlling the amount of nonmetallic inclusions, hard aluminum oxides, and especially large oxides over $30 \mu \mathrm{m} \cdot{ }^{[12-14]}$ Figure 5 shows the relationship between the bearing life and the oxygen content of steel. ${ }^{[14]}$ Lowering the amount of large inclusions by lowering the oxygen content to 3 to $6 \mathrm{ppm}$ has extended bearing life by almost 30 times in comparison with steels containing 20 ppm oxygen.

Although the solidification morphology of inclusions is of most importance in steel castings, the morphology of inclusions in wrought products is largely controlled by their mechanical behavior during steel processing, i.e., whether they are "hard" or "soft" relative to the steel matrix. ${ }^{[15]}$ Normally, pure alumina inclusions are nondeformable; thus, they should be avoided. Calcium treatment is well known to generate deformable inclusions and can lower the number of stringers of indigenous inclusions in steel. ${ }^{[9,15]}$

The remainder of this article is an extensive review on inclusions in ingot steel, their morphology, formation 
mechanisms, and possible remedies. Emphasis is on exogenous inclusions. Although this work is fundamental in nature, it has great practical significance.

\section{INCLUSIONS IN STEEL INGOTS AND RELATED PRODUCT DEFECTS}

Nonmetallic inclusions in steel are classified as indigenous inclusions or exogenous inclusions according to their sources.

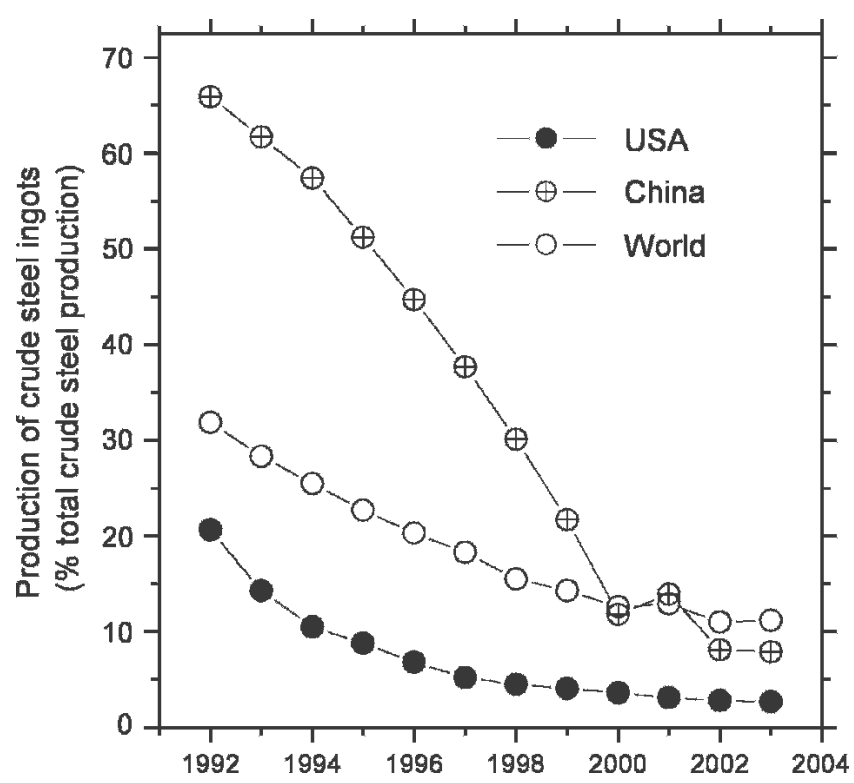

Fig. 1-Production of crude steel ingots in the United States and in the world. ${ }^{[1]}$

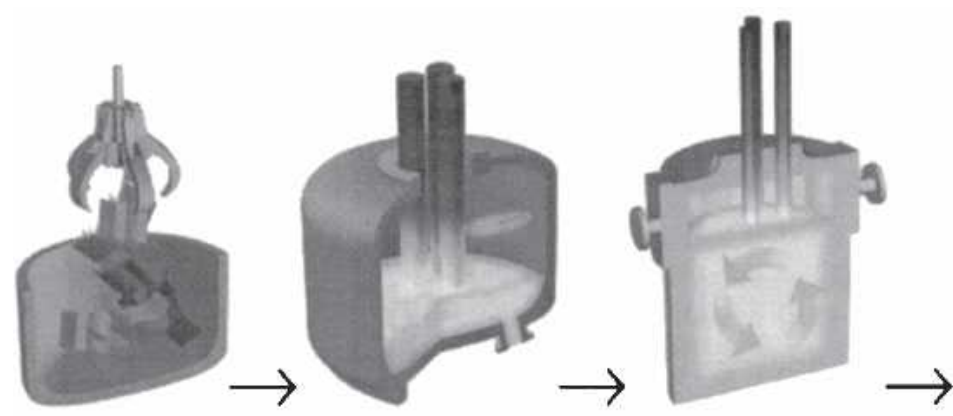

Scrap charging Melting Deoxidation and alloying

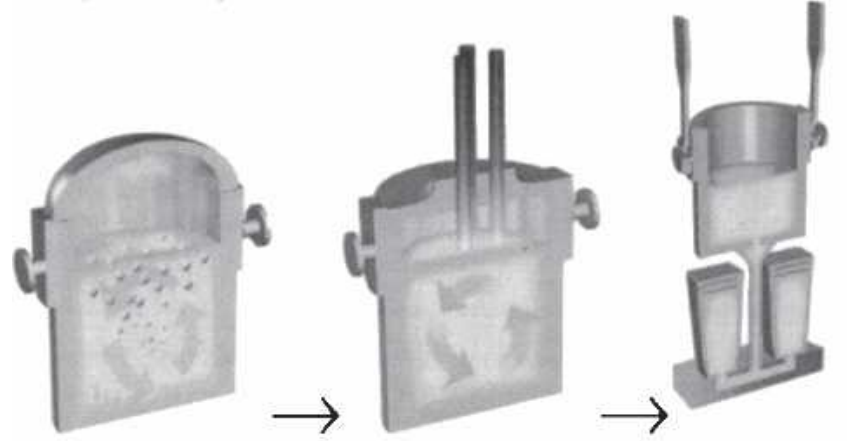

Vacuum degassing

\section{A. Indigenous Inclusions in Steel}

Indigenous inclusions are deoxidation products ${ }^{[9,16-46]}$ or inclusions that precipitate during cooling and solidification. ${ }^{[2,37,47-53]}$ Deoxidation products cause the majority of indigenous inclusions in steel, such as alumina inclusions in low-carbon Al-killed steel and silica inclusions in Si-killed steel. ${ }^{[9,31-46]}$ They are generated by the reaction between the dissolved oxygen and the added deoxidant, such as aluminum and silicon. Alumina inclusions are dendritic when formed in a high oxygen environment, ${ }^{[16,17,18]}$ as pictured in Figure 6(a). ${ }^{[17]}$ Cluster-type alumina inclusions from deoxidation or reoxidation, as shown in Figure $6(b)^{[19]}$ and Figure $7,{ }^{[19]}$ are typical of aluminum-killed steels. Figure 7 also indicates that the separate particles in the cluster are larger and the neck between clustered particles grows wider at higher temperature than those at lower temperature. There also exist coral-like alumina inclusions (Figure $\left.6(\mathrm{c})^{[17]}\right)$, which result from "Ostwald ripening" ${ }^{[20-26]}$ of originally dendritic or clustered alumina inclusions. Zhang and Pluschkell theoretically discussed the contribution of Ostwald ripening to the growth of inclusions. ${ }^{[54]}$ Alumina inclusions readily form three-dimensional clusters via collision and aggregation due to their high interfacial energy. Individual inclusions in the cluster range from 1 to $5 \mu \mathrm{m}$ in diameter ${ }^{[25,26]}$ Before they collide and aggregate, small alumina particles may be in the shape of sphere, flower plate, ${ }^{[27]}$ or polyhedral alumina, ${ }^{[18,27,29]}$ as shown in Figure $8 \cdot{ }^{[27]}$ Silica inclusions are generally spherical, ${ }^{[28,29,30]}$ owing to their liquid or glassy state in the molten steel. Silica inclusions can also agglomerate into clusters, as shown in Figure 9. ${ }^{[30]}$

The nucleation, growth, and removal of indigenous inclusions can be summarized as follows. Shortly after

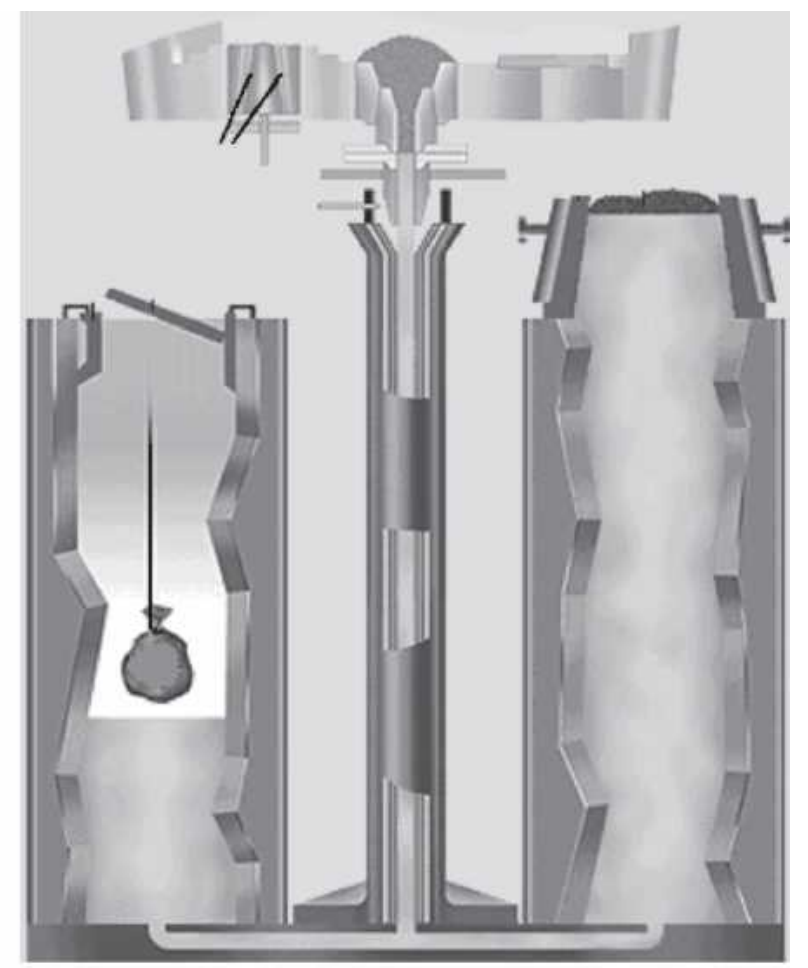

(b)

Fig. 2-Schematic of the steelmaking process. Left: Ovako Steel AB, Hofors, Sweden; ${ }^{[5]}$ and right: ingot bottom teeming process. ${ }^{[4]}$ 

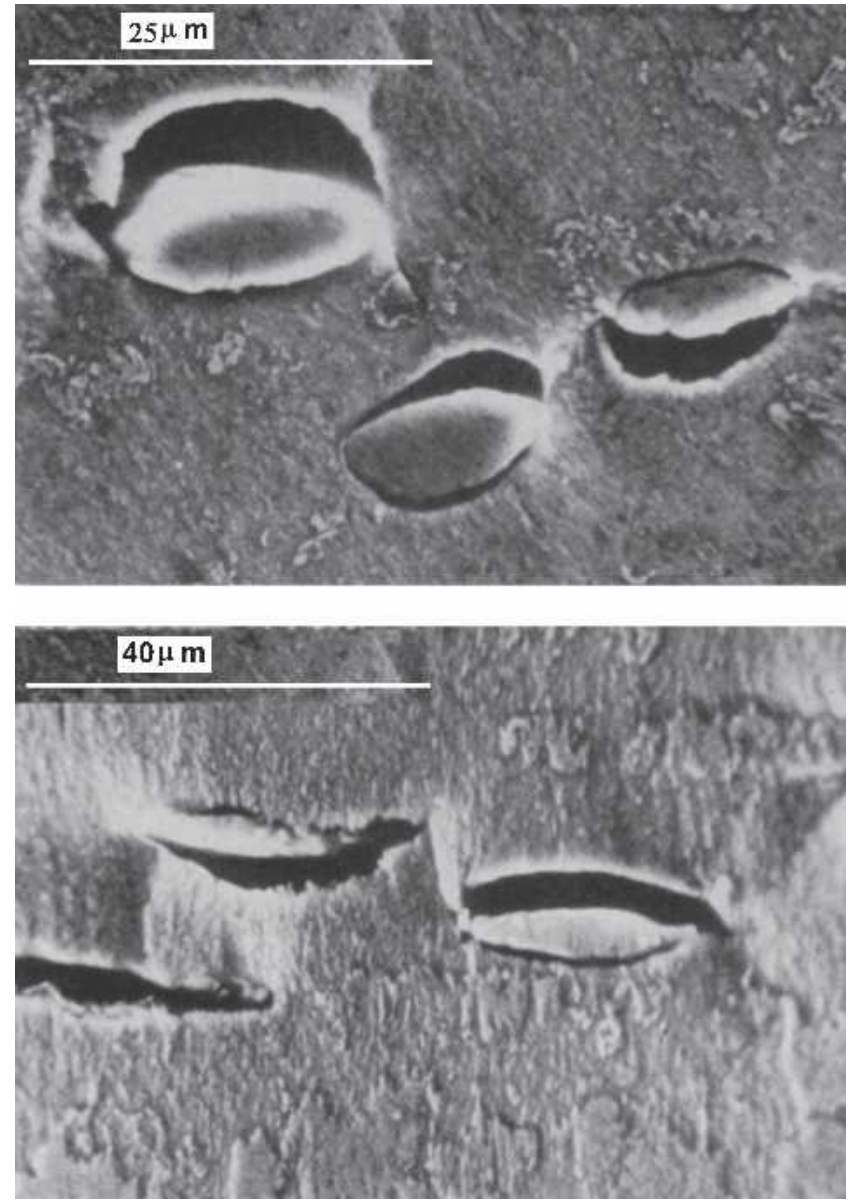

Fig. 3-Effect of inclusions on creation and linking of voids during deformation. ${ }^{[7]}$

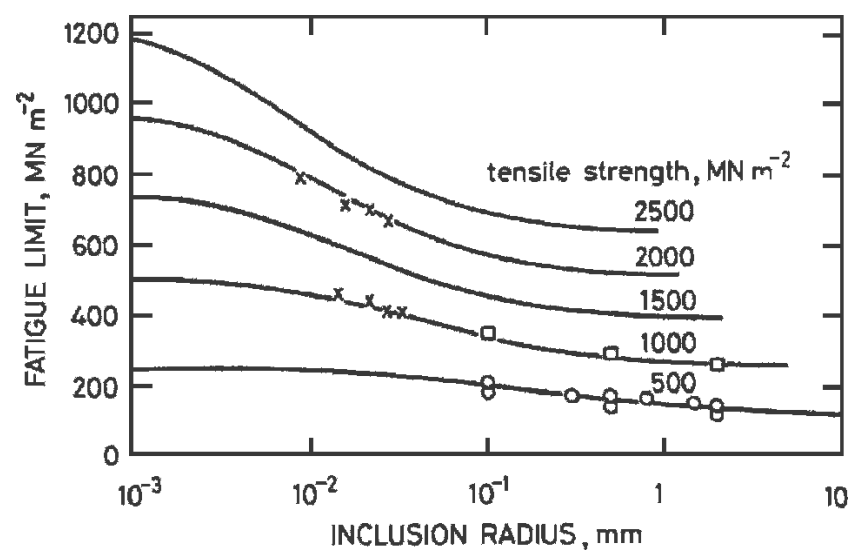

Fig. 4-Comparison between experimental (dots) and predicted fatigue limit (curve) for different inclusion sizes at different strength levels. ${ }^{[10]}$

adding deoxidizer, particles nucleate or precipitate, and quickly grow. Starting from the rapid supersaturation that occurs when alloys are released and dispersed into the melt, homogeneous nucleation is very fast, occurring in 1 to $10 \mu \mathrm{s} .{ }^{[54]}$ Inclusion growth is controlled by diffusion of the deoxidization elements and oxygen, ${ }^{[38,40,55-58]}$ local thermodynamics, ${ }^{[31,38,42,59-62]}$ Ostwald ripening, ${ }^{[40,55,58,63,64]}$ and Brownian collisions ${ }^{[38,40,55,56,58]}$ when inclusions are smaller than $1 \mu \mathrm{m}$.
Turbulent collision ${ }^{[40,55,56,63]}$ will control the growth of inclusions larger than $1 \mu \mathrm{m}$. Stokes collision ${ }^{[38,55,58,63,64]}$ may also contribute to the growth of inclusions. Zhang and Pluschkell recently have combined classic homogenous nucleation theory, thermodynamic analysis, and a multiple size grouping methodology to develop a fundamental model of nucleation and growth of alumina inclusions in steel using numerical simulation. ${ }^{[54]}$ This ground-breaking work incorporates the effects of temperature- and concentration-based supersaturation of alumina "pseudo-molecules," the coupled growth and dissolution of inclusions according to diffusion, Brownian motion, and turbulent collisions. The model predicts the phenomenon of Ostwald ripening, and explains why the central globule and secondary arms of a dendrite, or the individual spherical inclusions in an inclusion cluster, are consistently 1 to $5 \mu \mathrm{m}$ in size. This fact has been experimentally observed by many researchers. ${ }^{[16,17,19,39,40,65-71]}$ After growing large enough, inclusions can be removed from the molten steel by fluid flow transport and by attaching to the bubble surface (bubble floatation). Small inclusions stay suspended in the liquid steel and are passed on to the next process, while others are removed by the top slag and refractory walls by diffusion deoxidation and interfacial reactions.

During cooling, the concentration of dissolved oxygen/ nitrogen/sulfur in the liquid becomes larger, while the solubility of these elements decreases. Thus, inclusions such as alumina, ${ }^{[53]}$ silica, AlN,${ }^{[48,72]} \mathrm{TiN}$, and sulfide precipitate. Sulfides form interdendritically during solidification and often nucleate on oxides already present in the liquid steel. ${ }^{[73]}$ These inclusions are normally small $(<10 \mu \mathrm{m}){ }^{[47]}$ but may form large clusters. ${ }^{[74]}$ An example of sulfide inclusions $(\mathrm{MnS})$ in an ingot is shown in Figure 10. ${ }^{[74]}$ Figure 11 shows scanning electron microscopy (SEM) and transmission electron microscopy (TEM) micrographs of AlN inclusions in a high $\mathrm{Al}$ ingot $\left((\mathrm{a})\right.$ and $\left(\mathrm{a}^{\prime}\right)$ platelike, $(\mathrm{b})$ and $\left(\mathrm{b}^{\prime}\right)$ feathery, and (c) and ( $\left.c^{\prime}\right)$ branched rodlike), which formed both during and after solidification of the matrix. ${ }^{[48]}$ It is necessary to reheat ingots using temperature-time cycles to avoid precipitation of inclusions. ${ }^{[75]}$

Figure 12 clearly shows the drop in the total oxygen from tapping to solidification of the ingot after a constant addition of various deoxidants. The differences cannot be explained solely by the different equilibrium constants for dissolved oxygen and these deoxidants, as different inclusions also have different removal rates, due to mechanisms such as flotation. ${ }^{[7]}$ This figure shows that $\mathrm{Al}$ has the best deoxidation ability, followed by $\mathrm{Ti}, \mathrm{Zr}$, and $\mathrm{Si}$, which is lowest. This figure also indicates that inclusions can be removed by transport to the slag layer on the top surface during teeming and subsequent standing of the ingot.

Inclusion size distribution is of importance (Table I) because some defects of steel product may be only generated by large size inclusions. Only a few size distributions of inclusions in steel ingots were reported, and these data are summarized in Figure 13. ${ }^{[7,30,77]}$ Inclusions in this figure include both indigenous and exogenous inclusions. Franklin measured inclusion amounts as follows: 3- to $10-\mu \mathrm{m}$ diameter, $3.0 \times 10^{11} ; 10$ - to $20-\mu \mathrm{m}$ diameter, $2.5 \times$ $10^{10} ; 20$ - to $30-\mu \mathrm{m}$ diameter, $2.4 \times 10^{9} ; 30$ - to $40-\mu \mathrm{m}$ diameter, $4.5 \times 10^{8}$; 40- to $60-\mu \mathrm{m}$ diameter, $1.0 \times 10^{8}$; and $60-$ to $80-\mu \mathrm{m}$ diameter, $1.0 \times 10^{7}$. These inclusions 
Table I. Typical Steel Cleanliness Requirements Reported for Various Steel Grades

Steel Product Maximum Impurity Fraction

Maximum Inclusion Size

Automotive and deep drawing Sheet

Drawn and ironed cans

Line pipe

Ball bearings

Tire cord

Heavy plate steel

Wire

$$
\begin{aligned}
& {[\mathrm{C}] \leq 30 \mathrm{ppm},[\mathrm{N}] \leq 30 \mathrm{ppm}^{[260]}} \\
& {[\mathrm{C}] \leq 30 \mathrm{ppm},[\mathrm{N}] \leq 30 \mathrm{ppm}, \text { T.O. } \leq 20 \mathrm{ppm}^{[260]}} \\
& {[\mathrm{S}] \leq 30 \mathrm{ppm}^{[263]}[\mathrm{N}] \leq 35 \mathrm{ppm}, \text { T.O. } \leq 30 \mathrm{ppm}^{[263]}} \\
& {[\mathrm{N}] \leq 50 \mathrm{ppm}^{[264]}} \\
& \mathrm{T} . \mathrm{O} \leq 10 \mathrm{ppm}^{[11,262]} \\
& {[\mathrm{H}] \leq 2 \mathrm{ppm},[\mathrm{N}] \leq 40 \mathrm{ppm}, \text { T.O. } \leq 15 \mathrm{ppm}^{[263]}} \\
& {[\mathrm{H}] \leq 2 \mathrm{ppm},[\mathrm{N}] 30 \text { to } 40 \mathrm{ppm}, \text { T.O. } \leq 20 \mathrm{ppm}^{[263]}} \\
& {[\mathrm{N}] \leq 60 \mathrm{ppm}, \text { T.O. } \leq 30 \mathrm{ppm}^{[263]}}
\end{aligned}
$$

$100 \mu \mathrm{m}^{[260,261]}$
$20 \mu \mathrm{m}^{[260]}$
$100 \mu \mathrm{m}^{[260]}$
$15 \mu \mathrm{m}^{[111,263]}$
$10 \mu \mathrm{m}^{[263]} 20 \mu \mathrm{m}^{[261]}$
single inclusion $13 \mu \mathrm{m}^{[260]}$
$\quad$ cluster $200 \mu \mathrm{m}^{[260]}$
$20 \mu \mathrm{m}^{[263]}$

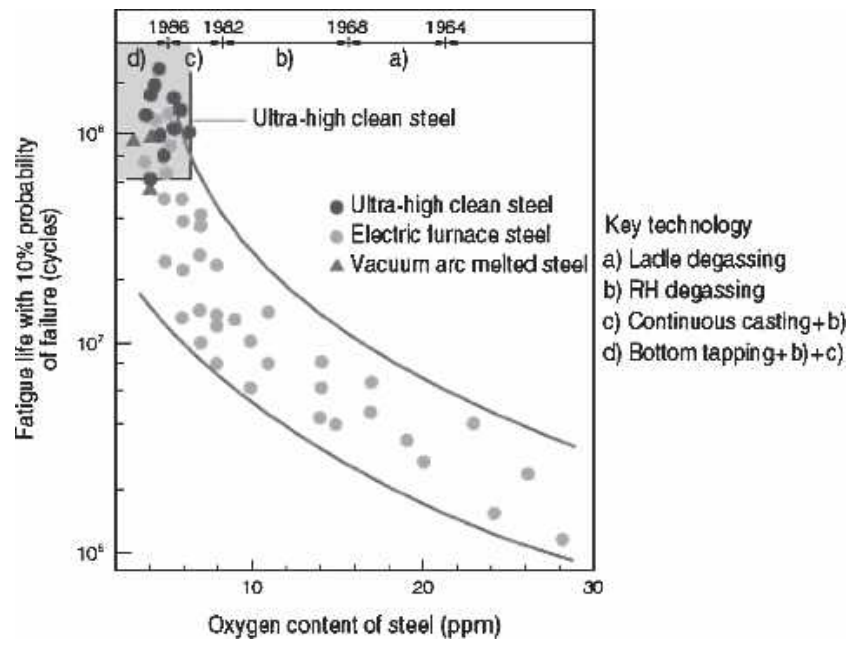

Fig. 5-Effect of oxide-inclusion content on fatigue life of bearing steels (lifetime defined as revolutions until fatigue flaking of the surfaces of inner and outer rings or steel balls). ${ }^{[14]}$

were mainly indigenous ones. ${ }^{[77]}$ Miki et al. measured the size distribution of large exogenous inclusions in a round steel ingot by the slime extraction test, where samples were located at the center, one-quarter diameter, and edge of the ingot at a height. ${ }^{[30]}$ Zhang et al. estimated the threedimensional size distribution of both indigenous and exogenous inclusions by converting the two-dimensional microscope observations at many different locations into three dimensions. ${ }^{[74]}$ This converting method assumes that the diameter of inclusions under the two-dimensional microscope observation is the same as that of the real threedimensional inclusions, and the number of inclusions observed by the two-dimensional microscope is the same number of inclusions in a volume of sample section area multiplied by the inclusion diameter as thickness. The difference between these measurements was partially due to the different bin size used. The latter measurements found fewer small inclusions, but similar numbers of large inclusions, including a significant number of very detrimental inclusions larger than $600 \mu \mathrm{m}$.

\section{B. Exogenous Inclusions in Steel}

Exogenous inclusions arise from unintended chemical and mechanical interaction of liquid steel with its surroundings. They generally have the most deleterious effect on machinability, surface quality, and mechanical properties because of their large size and location near the surface. In machining, they produce chatter, causing pits and gouges on the surface of machined sections, frequent breakage, and excessive tool wear. Exogenous inclusions come mainly from reoxidation, entrained slag as shown in Figure 14, lining erosion as shown in Figure 15, and chemical reactions. Because they are usually entrapped accidently during teeming and solidification, exogenous inclusions are sporadic. They easily float out, so they only concentrate in regions of the steel that solidify rapidly or where their escape by fluid transport and flotation is hampered. Consequently, they are often found near the ingot surface. Possible reasons for the entrapment of these large inclusions include the following: (1) late formation during steelmaking or transfer, leaving insufficient time for them to rise before entering the mold; (2) inadequate or high-rate teeming systems that encourage air entrainment or erosion of the trumpet, runner, and ingate refractories; (3) insufficient superheat: ${ }^{[78]}$; (4) inferior mold design such as reverse taper, depressions in the wall of ingot, or sharp corner between the wall and bottom; (5) fluid flow during ingot mold filling, which induces mold slag entrapment or reentrainment of floated inclusions before they fully enter the slag; (6) natural convection, which carries inclusions along the solidifying shell to the bottom of the ingot; and (7) the raining down of heavy equiaxed crystals that capture and carry the floating exogenous inclusions down to the bottom, or at least retard their floating. Exogenous inclusions have the following common characteristics. (1) Compound/multiphase composition (as shown in Figure 14(d)): Their size and composition depend on the type and order of deoxidant additions. In silicon-killed steels, for example, $\mathrm{MnO}-\mathrm{SiO}_{2}-\mathrm{Al}_{2} \mathrm{O}_{3}$ silicate deoxidation products interact with slag particles and pick up lime and magnesium. Calcium and magnesium aluminates can form in Al-killed steels, with compositions evolving in sequence $\mathrm{CaO}$. $6\left(\mathrm{Al}_{2} \mathrm{O}_{3}\right), \mathrm{CaO} \cdot 2\left(\mathrm{Al}_{2} \mathrm{O}_{3}\right), \mathrm{CaO} \cdot \mathrm{Al}_{2} \mathrm{O}_{3}$, as the aluminum content decreases. In electric furnace steelmaking, an alternative source of calcium and magnesium is provided by the reduction of refractories in heats made of strongly reducing slags. ${ }^{[15]}$ The following phenomena account for the complicated composition of exogenous inclusions. (2) Exogenous inclusions act as heterogeneous nucleus sites for precipitation of new inclusions during their motion in molten steel (Figure 16(a) ${ }^{[68]}$ ). (3) As exogenous inclusions move through the molten steel, due to their large size, they may entrap deoxidation inclusions such as $\mathrm{Al}_{2} \mathrm{O}_{3}$ on their 


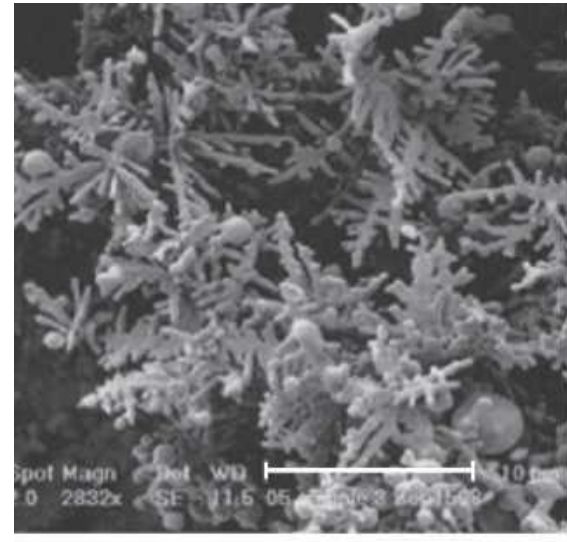

(a)

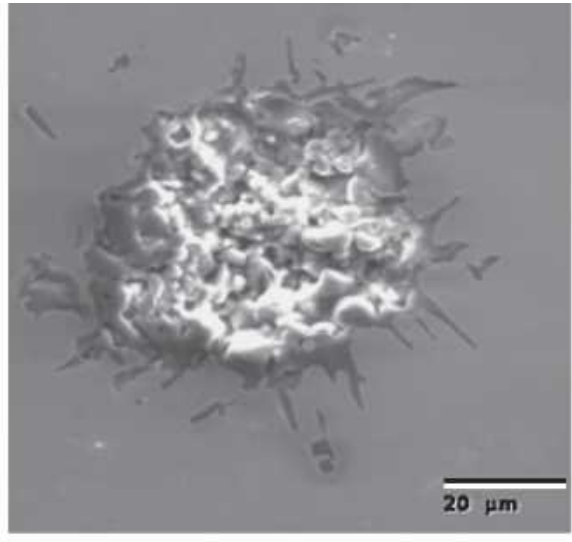

(b)

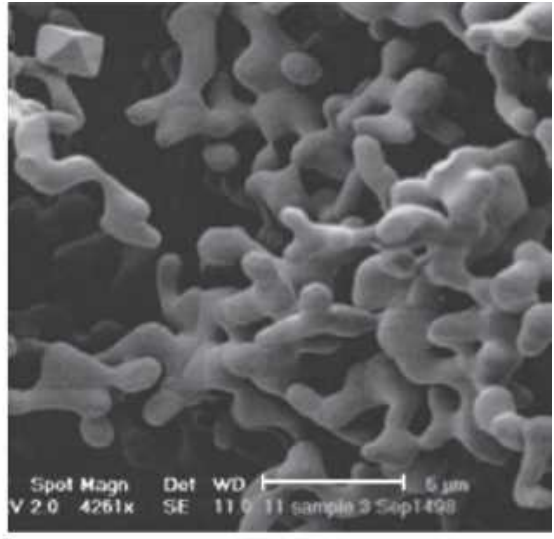

$(c)$

Fig. 6-Morphology of alumina inclusions generated during deoxidation of low-carbon Al-killed steels: $(a)$ dendritic and clustered alumina, ${ }^{[17]}(b)$ alumina cluster, ${ }^{[93]}$ and $(c)$ coral-like alumina. ${ }^{[17]}$
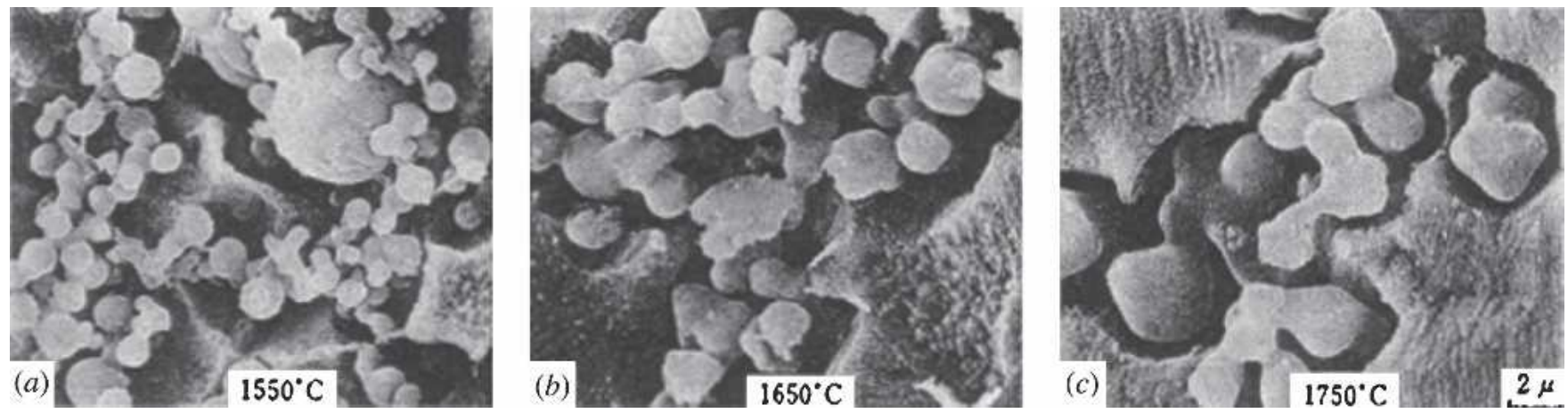

Fig. 7-Influence of temperature on size and neck growth of the constituent particles of alumina clusters in induction-stirred baths, sampling $20 \mathrm{~s}$ after Al deoxidation in a $20-\mathrm{kg}$ LCAK steel ingot (induction-stirred crucible). ${ }^{[19]}$

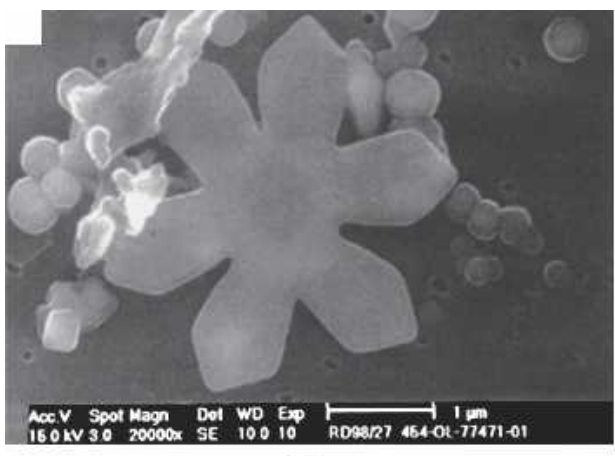

(a)

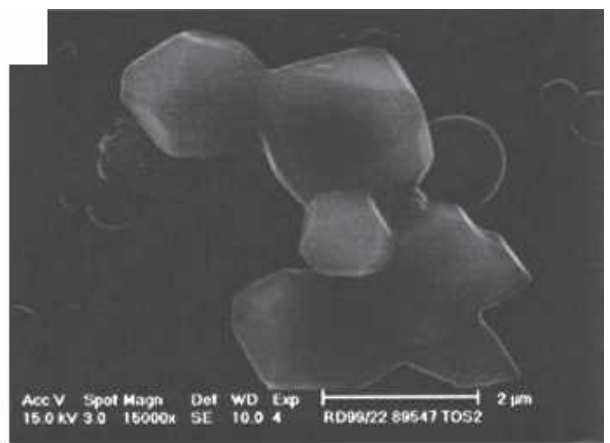

(b)

Fig. 8-Alumina inclusions formed during the deoxidation of LCAK steel: (a) flowerlike plate alumina and (b) aggregation of small polyhedral particles. ${ }^{\text {[27] }}$

surface (Figures 14(c) and 16(b) ${ }^{[79]}$ ). (4) Reactions between molten steel and $\mathrm{SiO}_{2}, \mathrm{FeO}$, and $\mathrm{MnO}$ in the slag and lining refractory can further augment inclusions transported near the slag-metal interface. (5) Slag or reoxidation inclusions may react with the lining refractories or dislodge further material into the steel. (6) Large size (usually $>50 \mu \mathrm{m}$ ): The maximum observed size of inclusions in steel from slag entrainment and from refractory erosion is given in Figure 17. ${ }^{[28]}$ This figure indicates that inclusions from refractory erosion are generally larger than those from slag entrainment. It should be mentioned that if there is a chemical reaction between liquid steel and slag, it is possible to have very small inclusions coming from the slag. (7) Irregular shape, differing from the spherical shape of entrained slag and small, single-phase deoxidation product particles. (8) Small number and low mass fraction, compared with small inclusions. (9) Sporadic distribution in the steel, contrasting with the even dispersal of small inclusions. (10) More deleterious to steel properties because of their large size. 

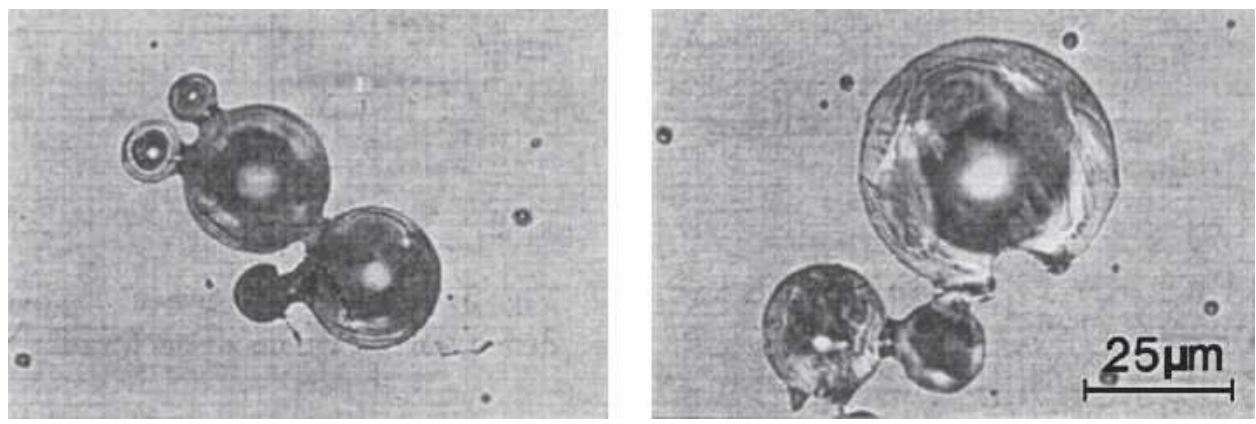

Fig. 9-Agglomeration of silica inclusions in an 80-kg ingot. ${ }^{[30]}$

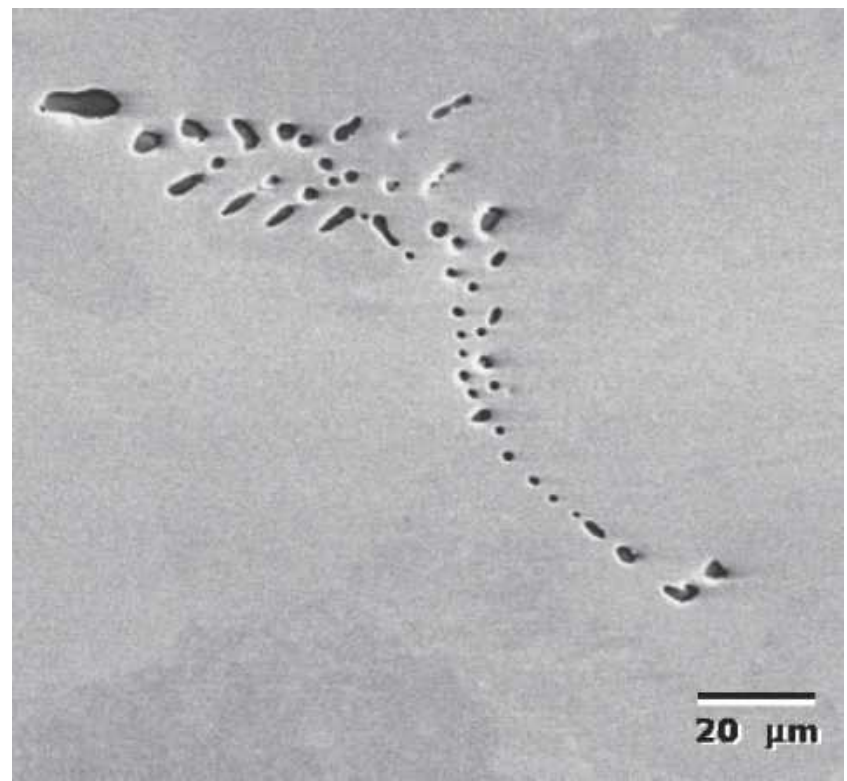

Fig. 10—Typical sulfide inclusion (MnS) in steel ingot. ${ }^{[93]}$

Table II. Sources of Macroinclusions in Ingot Steel ${ }^{[88]}$

Source

Approximate Frequency of Occurrence, pct

Attack or fluxing of refractories 58

High-alumina refractories

15

Deoxidation products

Slag

Slag + deoxidation products

The frequency of exogenous inclusions in slabs and plates forged from ingots is exemplified in Table $\mathrm{III}^{[8]}$ and Figure 13. Table III also shows that hot rolling and forging processes elongate the ingot inclusions to form stringers, which are longer in plates than in slabs, due to the greater thickness reduction.

Exogenous inclusions always depend on steelmaking and teeming practices, so their size, shape, and chemical composition often allow their source to be identified. Once the inclusion source is found, an effective process change usually can be made to eliminate that particular problem in the future. Unfortunately, exogenous inclusions often originate from a combination of several sources, so methods for their prevention are seldom simple. In addition to the features

already discussed, consideration should be given to the runner system and ingot shape design, hot-topping systems, teeming temperatures, and teeming rates. Only through attention to all inclusion sources and removal mechanisms can the incidence of large nonmetallic inclusions in steels be reduced.

\section{Defects in Ingot Steel Products}

Three books/sections have extensively discussed steelproduct defects. The British Iron and Steel Research Association compiled a compendium of surface defects in ingots and their products in 1958, ${ }^{[80]}$ and defined the causes of continuous casting defects in 1967. ${ }^{[81]}$ Ginzburg and Ballas reviewed the defects in cast slabs and hot-rolled products, many of which are related to inclusions. ${ }^{[82]}$ Some of the defects in steel products, such as scaling, arise during rolling. ${ }^{[82]}$ This section reviews only those defects related to inclusions in ingot casting, which include slag spots, line defects, slivers, blisters, pencil pipe, laps, and laminations.

Exogenous slag spots containing calcium, magnesium, aluminum, and oxygen have been observed. ${ }^{[83,84,86]}$ An example slag spot on a cold-rolled sheet is shown in Figure 18. ${ }^{[86]}$ Line defects or "slivers" appear on the surface of finished strip product, with widths of several tens of micrometers to millimeters and as long as 0.1 to $1 \mathrm{~m} \cdot{ }^{[87]}$ This surface defect is believed to result from rolling nonmetallic inclusions caught near the surface of the ingot or slab $(<15 \mathrm{~mm}$ from the surface). This defect is called blisters or pencil pipe if coupled with elongated bubbles. Three major types of line defects on cold-rolled sheets from steelmaking and casting sources include the following: (a) iron oxide, ${ }^{[83,84,85]}$ (b) alumina, ${ }^{[83,84,85]}$ and (c) exogenous oxide inclusions, ${ }^{[80,83-90]}$ such as mold slag. ${ }^{[3-85,90]}$ Examples are given in Figure 19. ${ }^{[88]}$ If the inclusions in these line defects include hard particles such as galaxite, chrome-galaxite, or spinels, then polishing the sheet may dislodge some of them and cause scratch marks (Figure 19(b)). ${ }^{[88]}$ Metallographic examination of pickled plate ends may reveal subsurface "tunnel" defects, also called laps, such as shown in Figure $20{ }^{[88]}$ Silicategalaxite inclusions are first exposed at the surface of the plate during rolling, and are progressively dissolved away during subsequent pickling to leave the tunnels. Traces of silicate inclusions were found in some tunnels by optical microscopy and microanalysis. ${ }^{[88]}$

If a sliver defect in a strip rolled from ingot steel is very severe, such as shown in Figure 21(a), its outer steel layer may tear away or "delaminate" from the surface, ${ }^{[80]}$ 

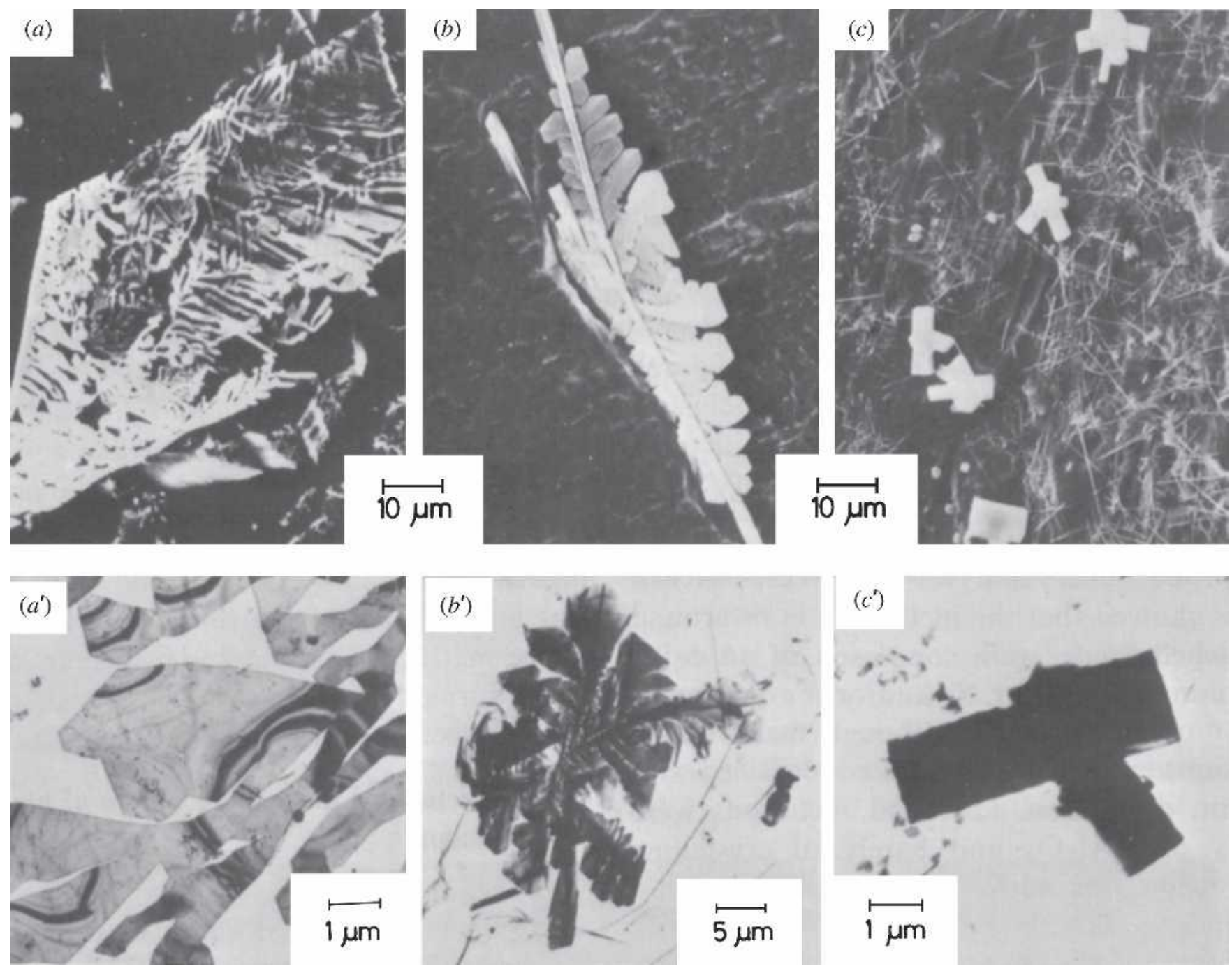

Fig. 11-SEM and TEM analysis of AlN inclusions in high-Al ingot: $(a)$ and $\left(a^{\prime}\right)$ platelike, $(b)$ and $\left(b^{\prime}\right)$ feathery, and $(c)$ and $\left(c^{\prime}\right)$ branched rodlike. ${ }^{[48]}$

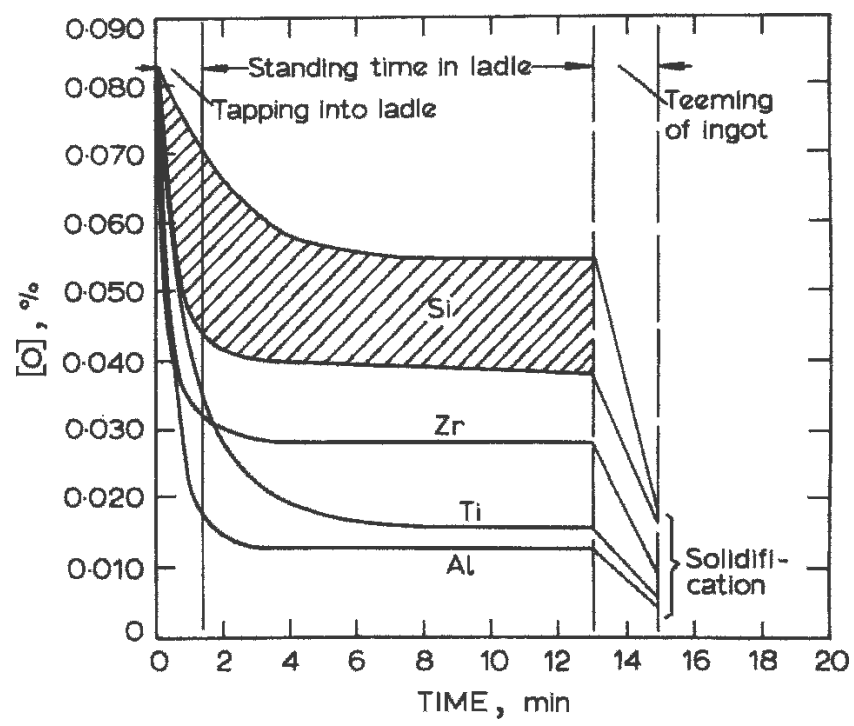

Fig. 12-Inclusion removal in the ladle after 3 pct additions of different deoxidizing metals. ${ }^{[76]}$

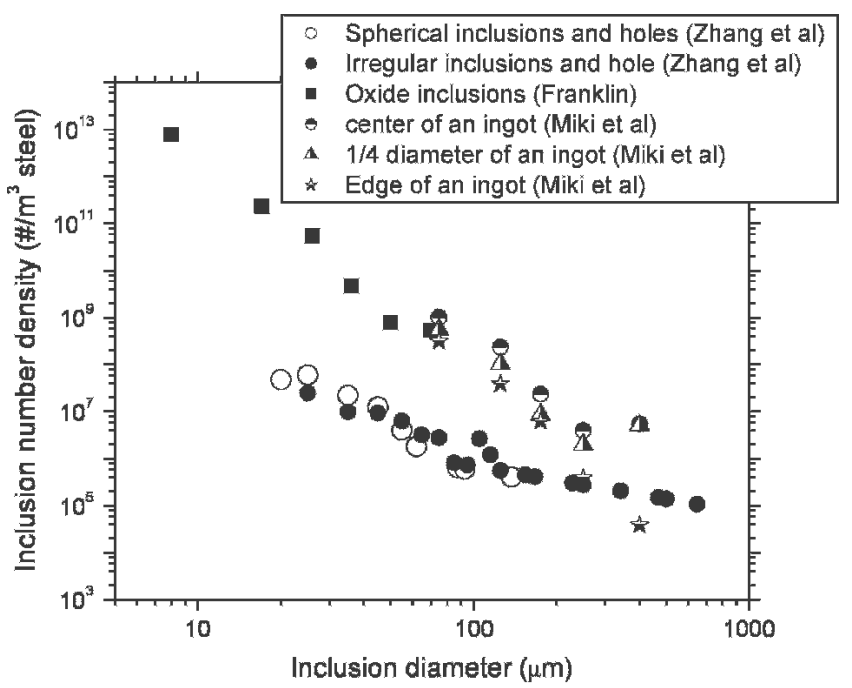

Fig. 13-Size distribution of inclusions in ingots measured by Franklin, ${ }^{[77]}$ Zhang et al..$^{[74]}$ and Miki et al. ${ }^{[30]}$ 


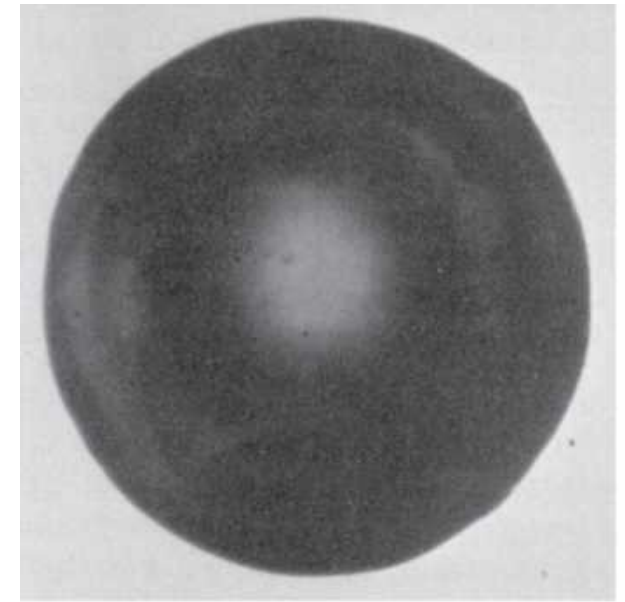

(a)

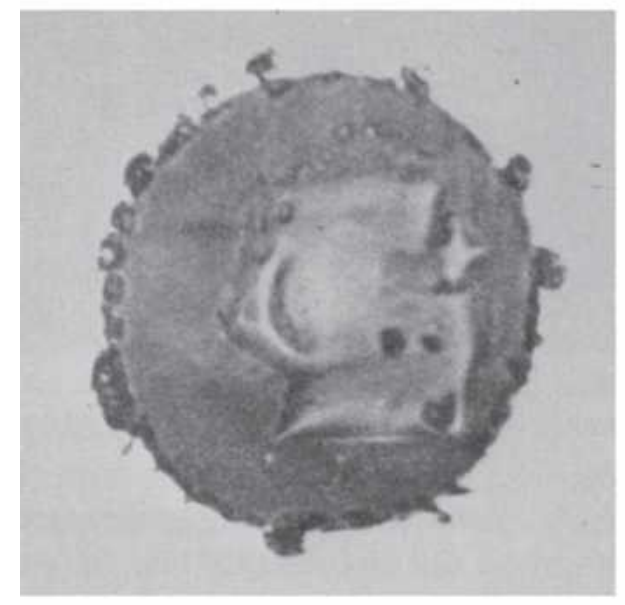

(c)

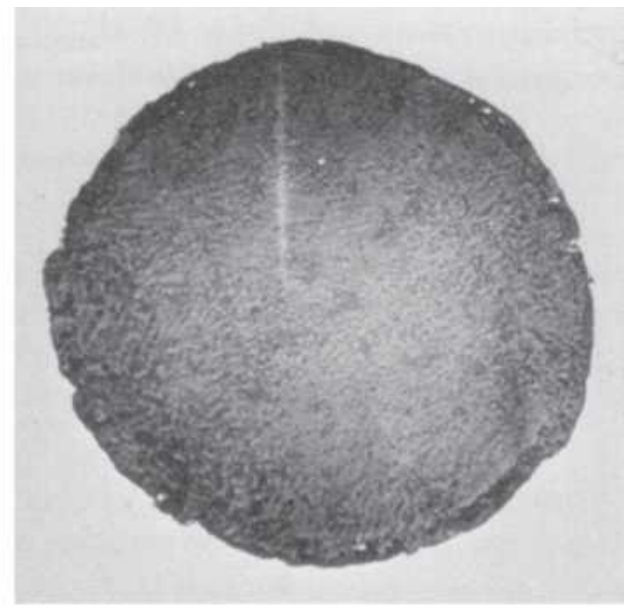

(b)

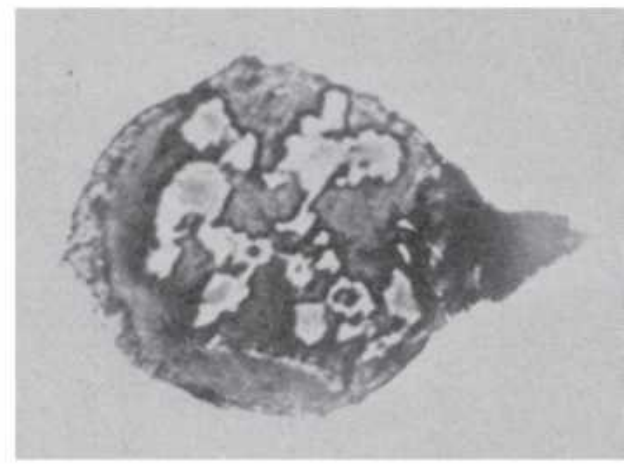

(d)

Fig. 14-Typical slag inclusions in steel ingot: $(a)$ calcium-alumina silicate, ${ }^{[29]}(b)$ either alumina silicate or a mixed oxide phase, ${ }^{[29]}(c)$ crystals of alumina on the surface of a globular slag inclusion, ${ }^{[47]}$ and $(d)$ globular inclusions of aluminosilicate with impregnated magnesium spinel. ${ }^{[47]}$

generating a defect called a "lamination." Such a "band" of defects was reported in rolled sheets of 08Yu steel, which was 25 to $30 \mathrm{~mm}$ in width and tens of meters in length. ${ }^{[91]}$ The source of this severe line defect was suggested to be oxides in surface cracks and clusters of inclusions in the surface layer of the ingot, which acted as substrates to form the bands during initial rolling. Figure 21 shows examples of line defects, including laminations. Most (60 to 70 pct) of the laminations in steel continuouscast products are from mold slag, ${ }^{[89]} 20$ to 30 pct from alumina clusters, and 5 to 10 pct are pure $\mathrm{FeO}$. Laminations are often combinations of bubble(s) and inclusions. ${ }^{[80,87]}$

If an elongated gas pocket entrapped below the surface of a rolled plate expands during annealing to form a smooth, slightly raised surface (ridge), the defect is called a "pencil blister," ${ }^{[87]}$ which originates from a "blow hole" or "pin hole" in the as-cast ingot. This surface defect has a tubular shape, typically $\sim 1$-mm wide and 150 - to $300-\mathrm{mm}$ long ${ }^{[87,90]}$ such as shown in Figure 21(d). It originates when a bubble is entrapped during casting and elongates into a gas pocket during annealing. Inclusions usually attach to the surface of the bubble during its motion through the molten steel, which worsen this defect. An example of a bubble with attached inclusions is shown in Figure 22. ${ }^{\text {992,93] }}$ Zhang and Taniguchi published an extensive literature review $^{[94,95]}$ and water model study ${ }^{[96]}$ on the interaction between inclusions and bubbles in molten steel.

\section{METHODS TO DETECT INCLUSIONS}

The amount, size distribution, shape, and composition of inclusions should be measured at all stages in steel production. Measurement techniques range from direct methods, which are accurate but costly, to indirect methods, which are fast and inexpensive, but are only reliable as relative indicators. Dawson et al. reviewed nine methods in 1988 and divided them into two categories: "off-line" methods and "online" methods. ${ }^{[97-104]}$ Zhang and Thomas reviewed over 30 methods to detect inclusions in steel. ${ }^{[11]}$

\section{A. Direct Methods}

There are several direct methods to evaluate steel cleanliness. Several traditional methods directly evaluate inclusions in two-dimensional sections through solidified 


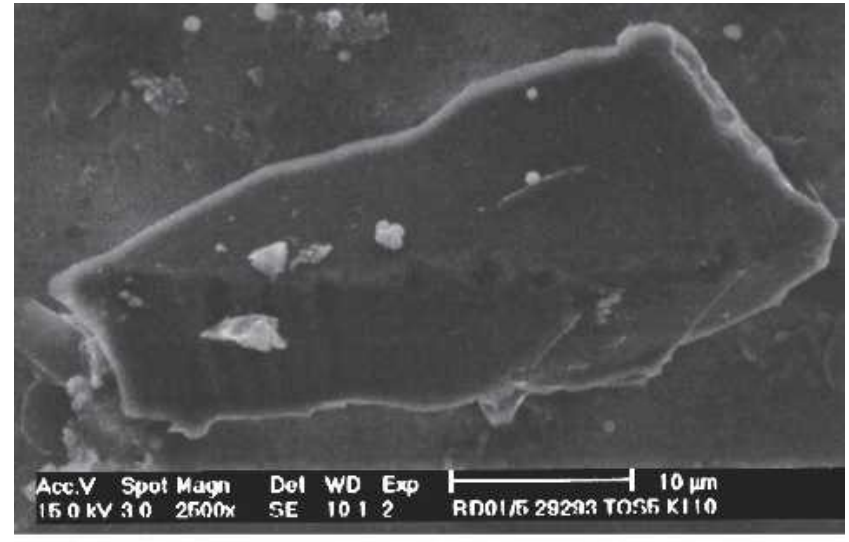

(a)

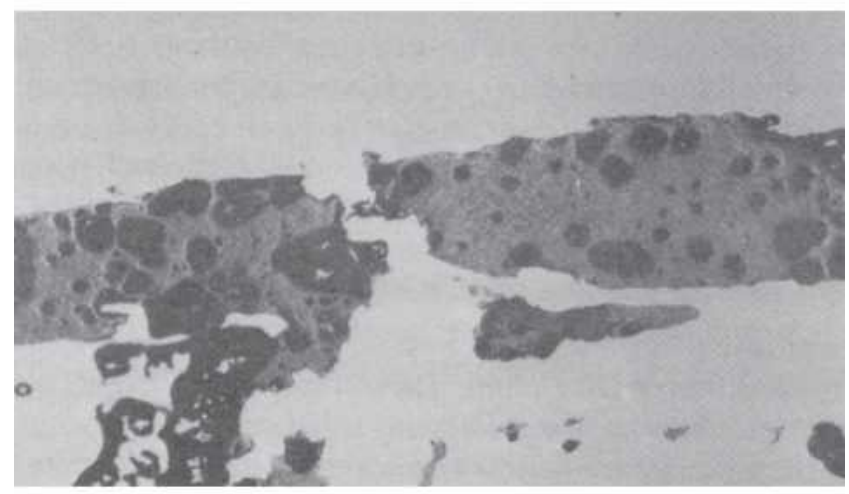

(b)

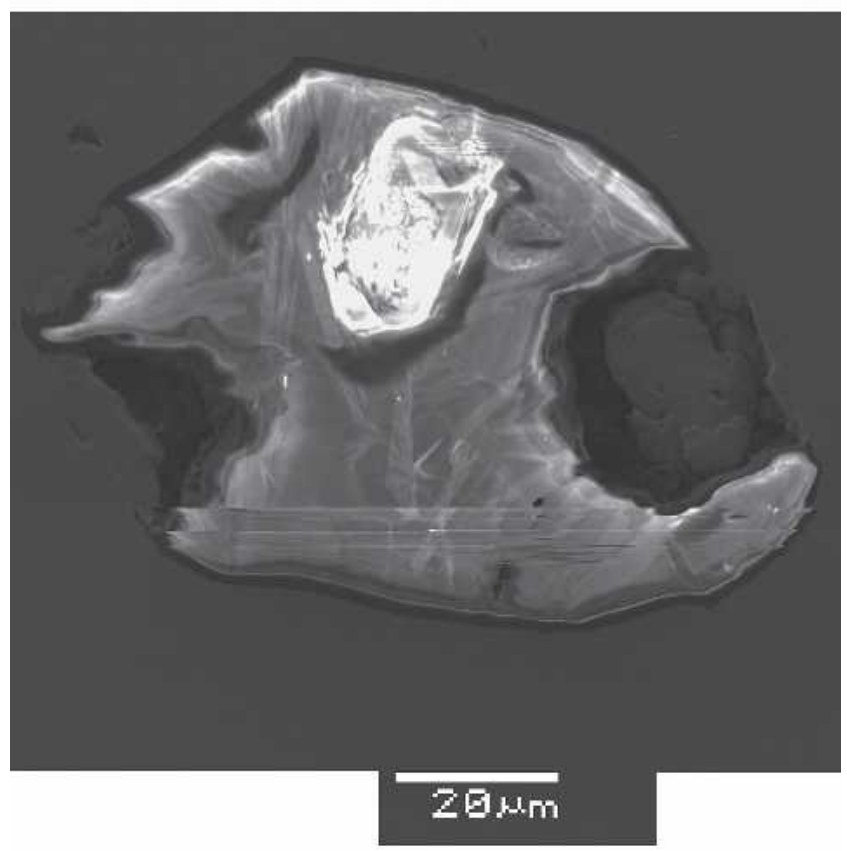

(c)

Fig. 15-Typical exogenous inclusions in steel: $(a)$ inclusions from lining refractory; ${ }^{[18]}(b)$ exogenous inclusion in C-Mn large forging (200 ton), 34 pct $\mathrm{MnO}-28$ pct $\mathrm{Al}_{2} \mathrm{O}_{3}-38$ pct $\mathrm{SiO}_{2} ;{ }^{[88]}$ and $(c) \mathrm{Al}_{2} \mathrm{O}_{3} 58.35$ pct, $\mathrm{SiO}_{2} 27.57$ pct, $\mathrm{CaO} 9.43$ pct, $\mathrm{Cr}_{2} \mathrm{O}_{3} 3.34$ pct, $\mathrm{FeO} 1.32$ pct. ${ }^{[3]}$

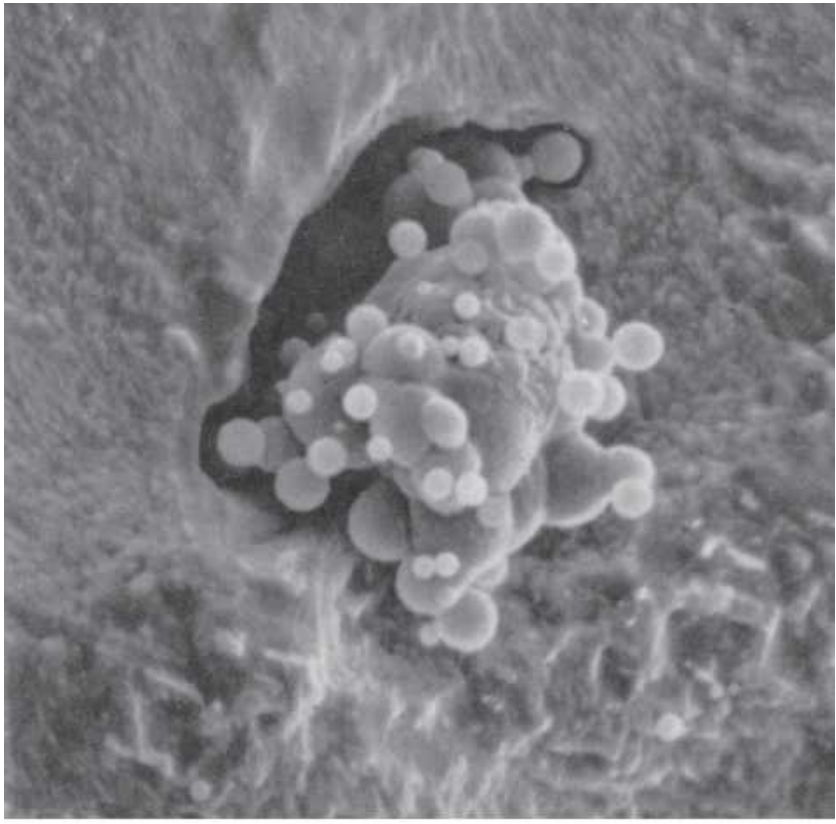

(a)

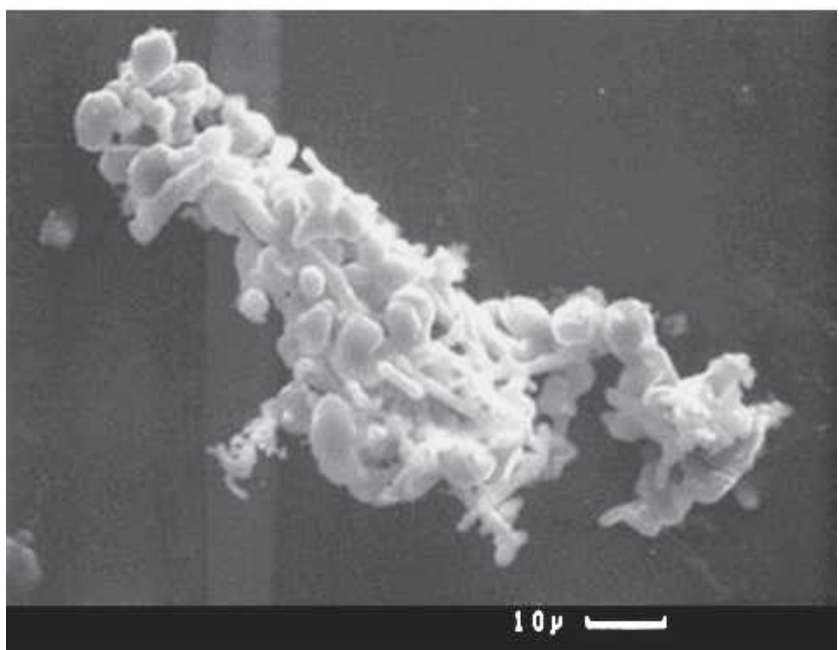

(b)

Fig. 16-(a) and (b) Inclusion clusters in Al-killed steel.

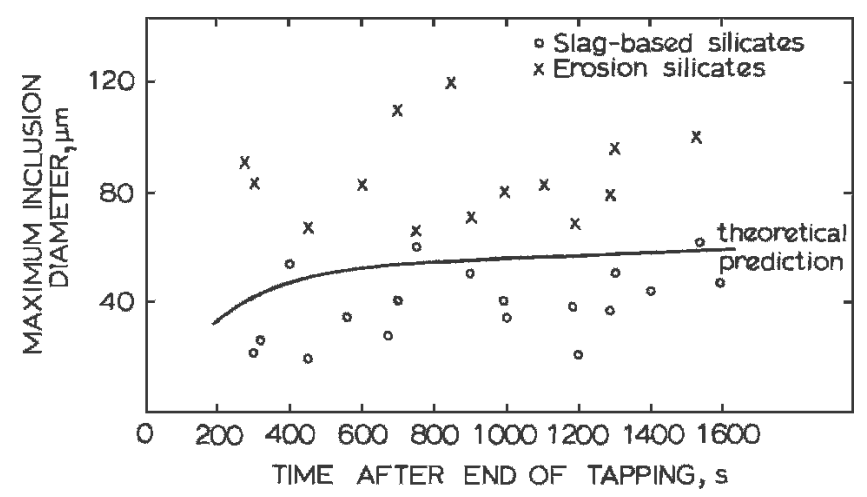

Fig. 17-Sizes of inclusions during teeming. ${ }^{[28]}$ 
Table III. Frequency of Large Exogenous Inclusions in Slab and Plate Detected by Image Scanning $\left(\mathrm{Number}^{\mathrm{cm}} \mathrm{cm}^{2}{ }^{[8]}\right.$

\begin{tabular}{|c|c|c|c|c|c|c|c|}
\hline \multicolumn{4}{|c|}{ Plate Scanning Investigation } & \multicolumn{4}{|c|}{ Slab Scanning Investigation } \\
\hline 100 to $250 \mu \mathrm{m}$ & 251 to $500 \mu \mathrm{m}$ & 501 to $1000 \mu \mathrm{m}$ & $1000 \mu \mathrm{m}$ & 30 to $50 \mu \mathrm{m}$ & 51 to $100 \mu \mathrm{m}$ & 101 to $250 \mu \mathrm{m}$ & $>250 \mu \mathrm{m}$ \\
\hline $\begin{array}{l}5 \text { to } 10 \text { sulfide } \\
5 \text { to } 15 \text { oxides }\end{array}$ & 2 to 7 oxides & 2 to 5 oxides & 1 to 3 oxides & $\begin{array}{l}10 \text { to } 15 \text { sulfide } \\
10 \text { to } 20 \text { oxides }\end{array}$ & $\begin{array}{l}1 \text { to } 3 \text { sulfide } \\
8 \text { to } 14 \text { oxides }\end{array}$ & 4 to 7 oxide & 1 to 3 oxides \\
\hline
\end{tabular}

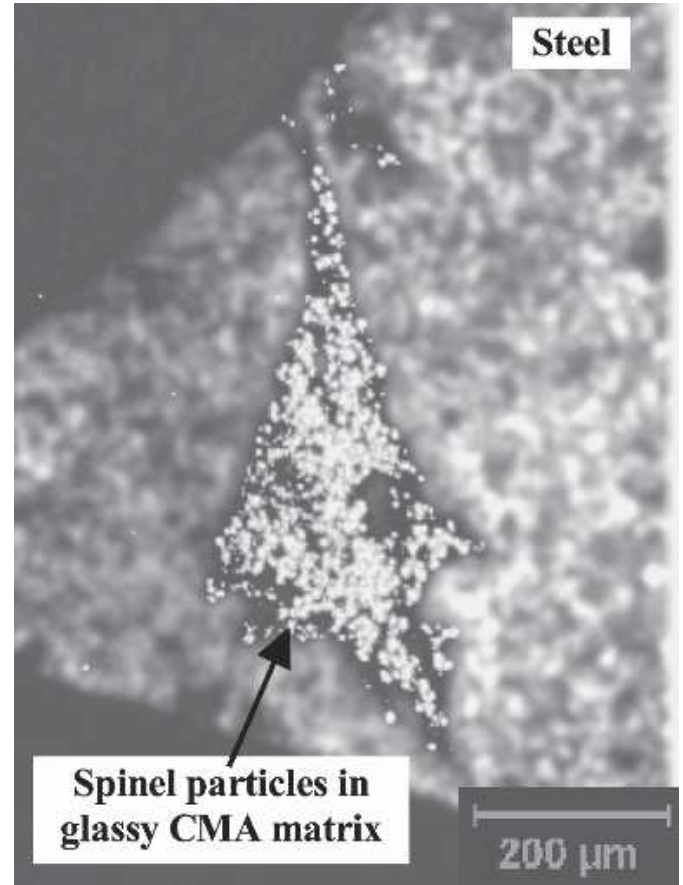

Fig. 18-A slag spot defect on a cold-rolled sheet. ${ }^{[86]}$

product samples, including metallograph microscope observation, ${ }^{[10,98,105,106]}$ image analysis, ${ }^{[8,10,107]}$ sulfur print, ${ }^{[108,109]}$ scanning electron microscopy, ${ }^{[17,110]}$ optical emission spectrometry with pulse discrimination analysis, ${ }^{[109,111-114]}$ laser microprobe mass spectrometry, ${ }^{[15]} \mathrm{X}$-ray photoelectron spectroscopy ${ }^{[110]}$ Auger electron spectroscopy, ${ }^{[110]}$ and cathodoluminescence microscope. ${ }^{[86]}$ Several methods directly measure inclusions in the three-dimensional steel matrix. Several of these scan through the sample with ultrasound or X-rays: conventional ultrasonic scanning, ${ }^{[12,13,116,117]}$ Mannesmann inclusion detection by analysis surfboards ${ }^{[118]}$ (also called liquid sampling hot rolling ${ }^{[5,109,119]}$ ), scanning acoustic microscope ${ }^{[120]} \mathrm{X}$-ray detection, ${ }^{[101,121-124]}$ chemical dissolution, ${ }^{[17,68,100,125]}$ slime (electrolysis) ${ }^{[100,108,114,126]}$ electron beam melting, ${ }^{[127,128]}$ cold crucible melting, ${ }^{[109]}$ fractional thermal decomposition, ${ }^{[114]}$ and magnetic particle inspection. ${ }^{[99,129,130]}$ Several methods determine the threedimensional inclusion size distributions after the inclusions are extracted from the steel: Coulter counter analysis, ${ }^{[131]}$ photoscattering method, ${ }^{[106,132]}$ and laser-diffraction particle size analyzer. ${ }^{[109]}$ Several methods directly detect the inclusion amount and size distribution in the molten melt: ultrasonic techniques for the liquid system, ${ }^{[104,133-135]}$ liquid metal cleanliness analyzer, ${ }^{[135,136]}$ confocal scanning laser microscope,$^{[137,138,139]}$ and electromagnetic visualization. ${ }^{[140]}$

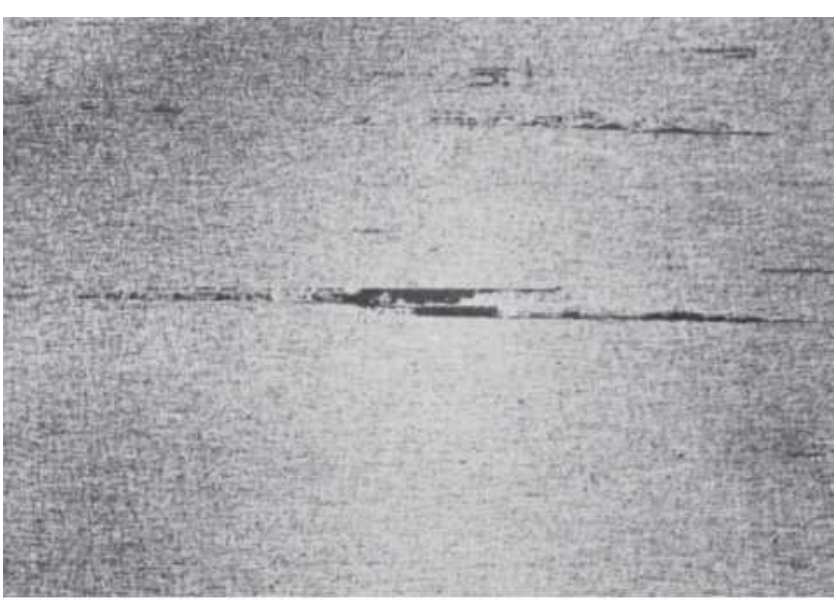

(a)

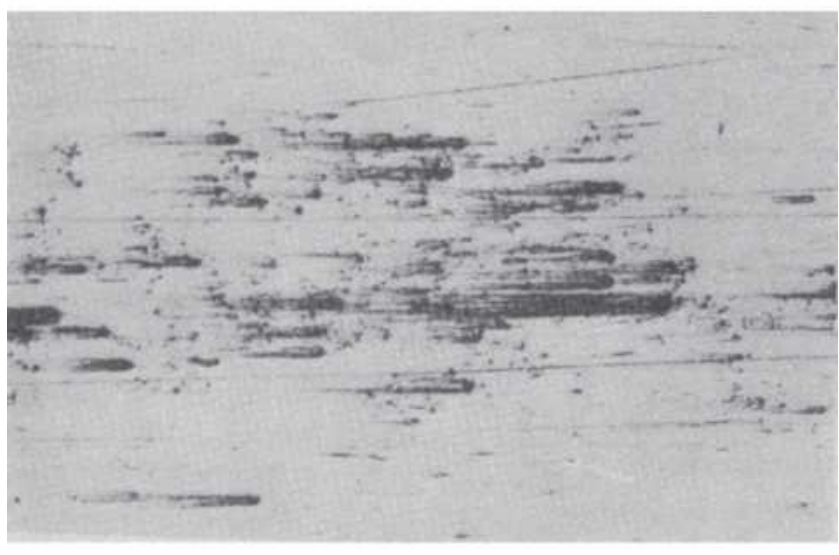

$x 120$

(b)

Fig. 19-(a) and (b) Line shell defects on stainless flat-rolled product from ingot. ${ }^{[88]}$

\section{B. Indirect Methods}

Owing to the cost, time requirements, and sampling difficulties of direct inclusion measurements, steel cleanliness is generally measured in the steel industry using total oxygen, nitrogen pickup, and other indirect methods.

\section{Total oxygen measurement ${ }^{[141,142,143]}$}

The total oxygen (T.O.) in the steel is the sum of the free oxygen (dissolved oxygen) and the oxygen combined as nonmetallic inclusions. Free oxygen, or "active" oxygen, can be measured relatively easily using oxygen sensors. It is controlled mainly by equilibrium thermodynamics with deoxidizing elements such as aluminum. Because the free oxygen does not vary much $\left(3\right.$ to $5 \mathrm{ppm}$ at $1600{ }^{\circ} \mathrm{C}$ for 
Al-killed steel $\left.{ }^{[144,145]}\right)$, the total oxygen is a reasonable indirect measure of the total amount of oxide inclusions in the steel. Due to the small amount of large inclusions in the steel and the small sample size for T.O. measurement (normally $20 \mathrm{~g}$ ), it is rare to find a large inclusion in the sample using this method. Even if a sample has a large inclusion, it is likely discounted due to its anomalously high reading. Thus, T.O. content really represents the level of small oxide inclusions only.

\section{Nitrogen pickup}

The difference in nitrogen content between steelmaking vessels is an indicator of the air entrained during transfer

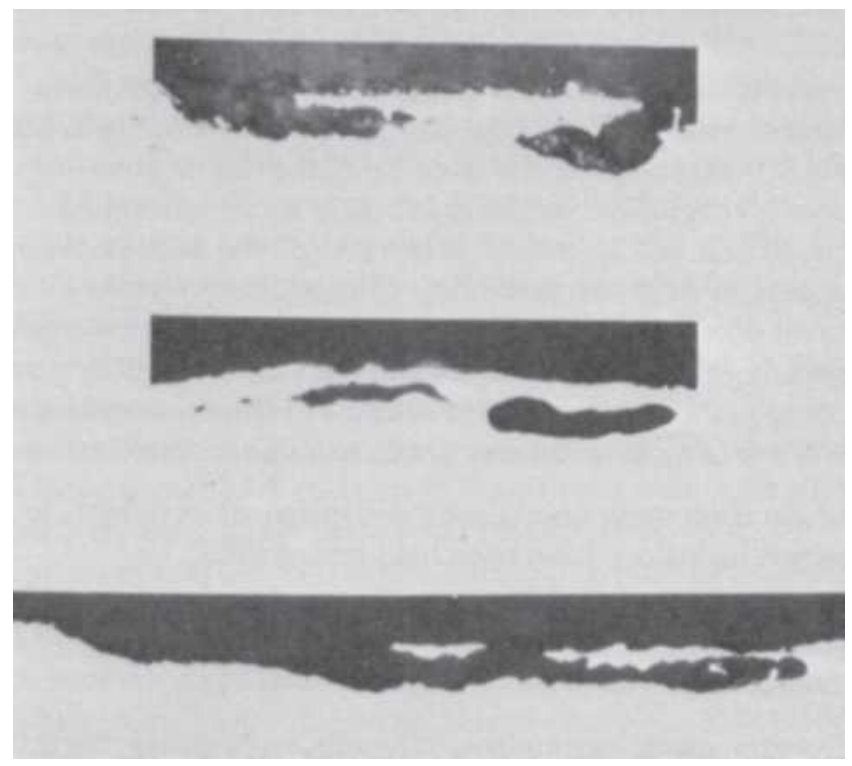

Fig. 20-Example of tunnel or lap defect on rolled plate due to pickled-out silicate inclusions. ${ }^{[88]}$ operations. For example, Weirton restricted nitrogen pickup from ladle to tundish to less than $10 \mathrm{ppm}$ for critical clean steel applications. ${ }^{[146,147]}$ After deoxidation, the low dissolved oxygen content of the steel enables rapid absorption of air. Nitrogen pickup thus serves as a crude indirect measure of total oxygen, steel cleanliness, and quality problems from reoxidation inclusions.

\section{Concentration measurement for some elements}

For low-carbon-aluminum-killed (LCAK) steels, a drop in the dissolved aluminum content also indicates that reoxidation has occurred. However, this indicator is a less accurate measure than nitrogen pickup because $\mathrm{Al}$ can also be reoxidized by slag. Silicon pickup and manganese pickup can be used to evaluate reoxidation as well.

\section{Slag composition measurement}

First, analysis of the slag composition evolution by measurements before and after operations can be interpreted to estimate inclusion absorption to the slag. Second, the origin of a complex oxide inclusion can be traced to slag entrainment by matching the mineral and element fractions in the slag with the inclusion composition. ${ }^{[108]}$ These methods are not easy due to sampling difficulties and complicated thermodynamic equilibrium.

\section{Lining refractory ${ }^{[89,148-153]}$}

Analysis of the lining refractory composition before and after operations can be used to estimate inclusion absorption to the lining and the lining erosion. Also, the origin of a complex oxide inclusion can be traced to lining refractory erosion by matching the mineral and element fractions in the slag with the inclusion composition. ${ }^{[108]}$

\section{Tracer studies for slag entrainment and} lining erosion ${ }^{[83,89,90,122,154-160]}$

Tracer oxides can be added into slags and linings in the ladle, tundish, trumpet, runners, mold, or hot-top

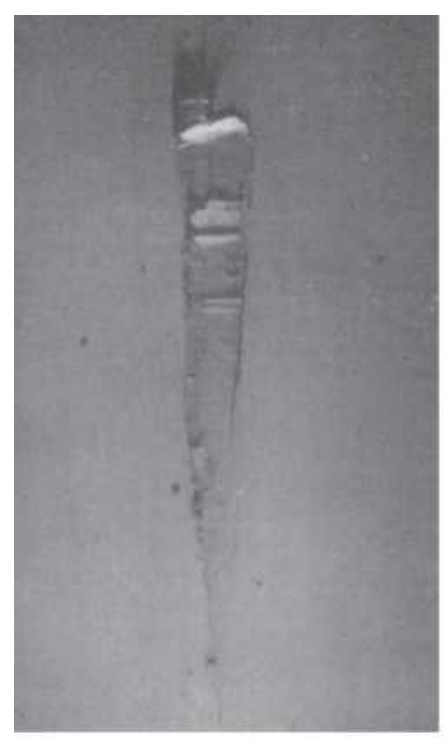

(a)

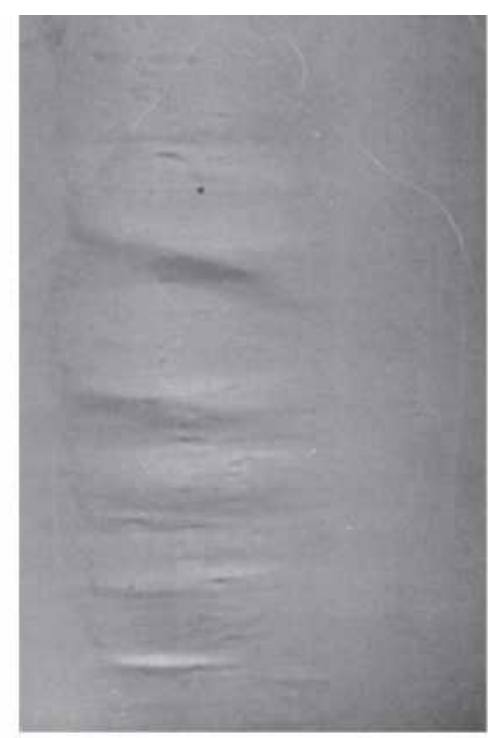

(b)

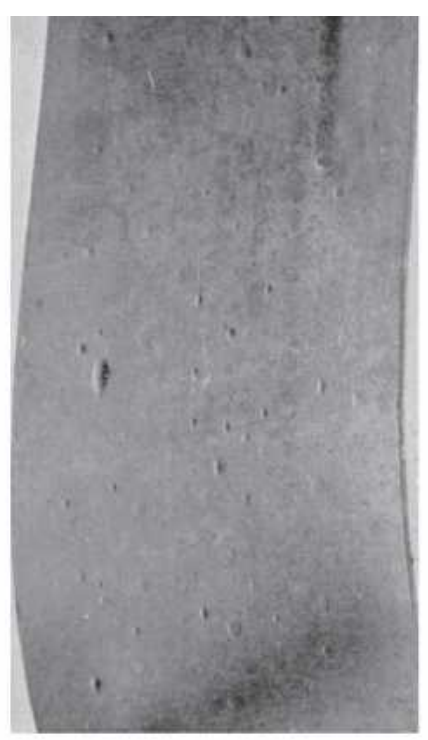

(c)

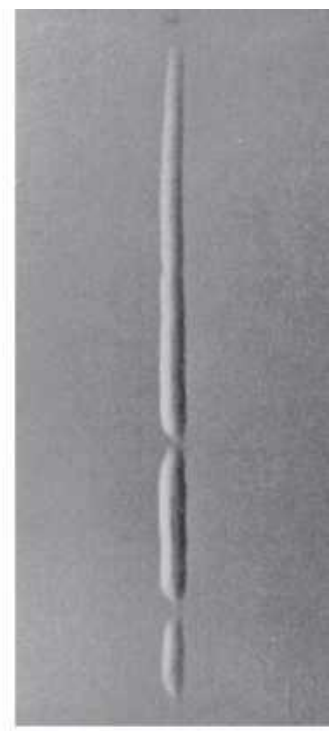

(d)

Fig. 21-Defects on surface of steel strip rolled from ingot steel: $(a)$ sliver, $(b)$ and $(c)$ blisters, and $(d)$ pipe lamination. ${ }^{\text {[80] }}$ 

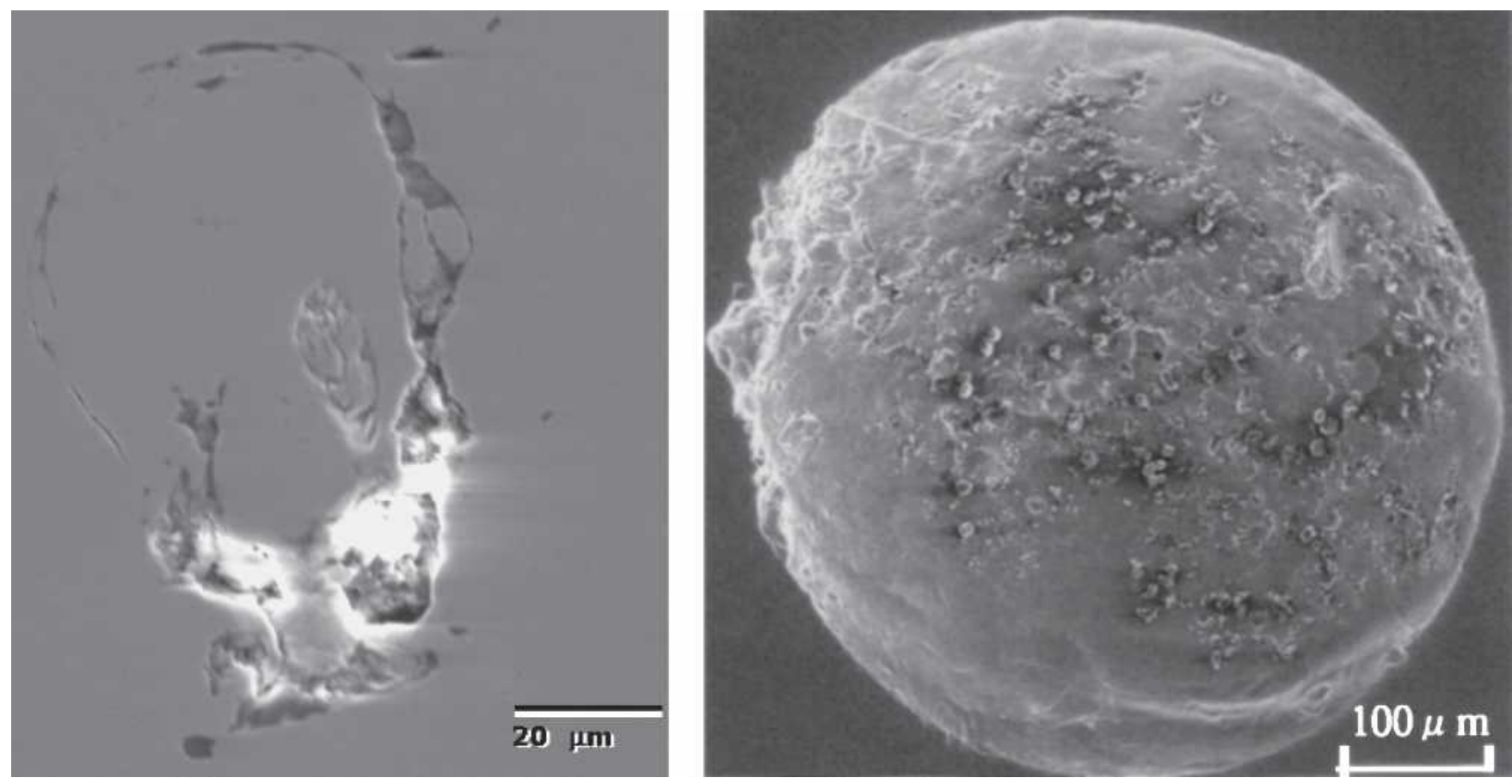

Fig. 22-Inclusions outlining the former surface of bubbles captured in ingot steel (left) ${ }^{[93]}$ and in continuous cast steel (right). ${ }^{[92]}$

compounds. Typical inclusions in the steel are then analyzed by SEM and other methods. The presence of tracer oxides in these inclusions thus reveals their source. Tracer metals such as La can also be added into molten steel before and during steel deoxidation to study the evolution and distribution of deoxidation-based inclusions in ingot ${ }^{[122]}$ and in slab. ${ }^{[158]}$ Several such tracer studies are summarized in Table IV.

The ultimate measure of cleanliness is to use destructive mechanical tests to measure strength, formability, deep drawing, or bending properties of the final sheet product, or fatigue life of test specimens or product samples. Other sheet tests include the hydrogen-induced crack test and magnetoscopy. ${ }^{[18]}$ Another is the inclusion inspection in the ultra-sonic fatigue test. ${ }^{[161]}$ These tests reveal the true effects of inclusions, including the potential benefit of very small inclusions $(<1 \mu \mathrm{m})$, which should not count against cleanliness.

The previous discussion shows that there is no single ideal method to evaluate steel cleanliness. Some methods are better for quality monitoring while others are better for problem investigation. Thus, it is necessary to combine several methods together to give a more accurate evaluation of steel cleanliness in a given operation. For example, Nippon Steel used total oxygen measurement and EB melting for small inclusions and the slime method and EB-EV for large inclusions. ${ }^{[14]}$ BaoSteel employed total oxygen measurement, MMO, XPS, and SEM for small inclusions, slime and SEM for large inclusions, nitrogen pickup for reoxidation, and slag composition analysis to investigate inclusion absorption and slag entrainment. ${ }^{[108]}$ Finally, ultrasonic scanning, microscope observation, sulfur printing, slime electrolysis, X-ray, SEM, slag composition analysis, and refractory observation are suitable methods to detect exogenous inclusions.

\section{FORMATION MECHANISMS OF EXOGENOUS INCLUSIONS}

Exogenous inclusions in steel ingot casting have many sources, which have been the subject of several plant studies. Thomas et al. ${ }^{[162]}$ investigated the sources of exogenous nonmetallic inclusions in 25 heats of steel ingots and identified that 77 pct of the heats were affected by reoxidation products, 46 pet by hot-top refractories, 38 pct by ingot top crust, 35 pet by hot topping compounds, 8 pet by slag, and 23 pct by others. An evaluation of various macroinclusion sources by Leach found that lining erosion is the most serious problem, as ranked in Table II. ${ }^{[88]}$ Cramb extensively reviewed inclusion formation in foundry processing and found exogenous inclusions form mainly from reoxidation, slag entrainment, and lining erosion. ${ }^{[163]}$ An investigation by Blair et al. found similar sources of macroinclusions in high alloy steel ingot casting: 43 pct by reoxidation, 35 pct by molding materials, 14 pct by refractory lining, and 3 pct by slag. ${ }^{[164]}$ The rejection rate of steel rounds for ball bearings was reduced greatly by improving refractories, improving mold flux, preventing slag entrapment, using bottom pouring casting, and modifying roll pass design. ${ }^{[165]}$ The most important formation mechanisms of exogenous inclusions are summarized as follows.

\section{A. Reoxidation Mechanisms}

Reoxidation during teeming is a major source of exogenous inclusions in ingot steel. ${ }^{[15]}$ Reoxidation products are also the most common form of large macroinclusions in foundry castings, such as the alumina clusters shown in Figure 6. The stages in formation of alumina clusters are shown in Figure 23, ${ }^{[15]}$ including the evolution of the clusters by $\mathrm{Si}$ and $\mathrm{Mn}$. Alumina clusters can also form by deoxidation. ${ }^{[17]}$ 
Table IV. Tracer Oxides Studies to Identify Exogenous Inclusion Sources

\begin{tabular}{|c|c|c|c|}
\hline Researches & Description & Year & Reference \\
\hline Mori et al. & $\mathrm{La}_{2} \mathrm{O}_{3}$ oxide added to steelmaking furnace slag & 1965 & 265 \\
\hline Middleton et al. & $\begin{array}{l}\text { cerium oxide }\left(\mathrm{CeO}_{2}\right) \text { to sand } \\
\text { furnace slag: } \mathrm{Ba} \\
\text { ladle refractory: } \mathrm{Zr} \text { and } \\
\text { Ba nozzle sleeves: } \mathrm{Ba}\end{array}$ & 1967 & 154 \\
\hline Ichinoe et al. & La was plugged into aluminum to be added in the mold & 1970 & 122 \\
\hline Bemko et al. & $\mathrm{Ba}$ was added into the slag and lining & 1972 & 155 \\
\hline Zeder and Pocze & $\begin{array}{l}\text { La to ladle lining, Yb to stopper-rod in ladle, Sm to trumpet bricks, Eu to } \\
\text { spider bricks, Ho to runner bricks }\end{array}$ & 1980 & 156 \\
\hline Komai et al. & $\mathrm{SrO}$ to tundish slag for the continuous casting of low-carbon Al-killed steel & 1981 & 157 \\
\hline Byrne et al. & $\begin{array}{l}\text { barium oxide }(\mathrm{BaO}) \text { added to the ladle slag } \\
\text { cerium oxide }\left(\mathrm{CeO}_{2}\right) \text { added to the tundish slag } \\
\text { strontium oxide }\left(\mathrm{SrO}_{2}\right) \text { added to the mold slag }\end{array}$ & 1985 & 83 \\
\hline Byrne and Cramb & cerium oxide $\left(\mathrm{CeO}_{2}\right)$ added to the ladle shroud cell and the tundish slag & 1988 & 89 \\
\hline Burty et al. & $\begin{array}{l}\text { La was added into steel during RHOB after Al killing; then, } 5 \text { min stirring was } \\
\text { used, to evaluate reoxidation, understand clogging at SEN, and understand } \\
\text { inclusion floating to top slag. }\end{array}$ & 1994 & 158 \\
\hline Zhang and Cai & $\begin{array}{l}\mathrm{BaCO}_{3} \text { to ladle slag, } \mathrm{SrCO}_{3} \text { to tundish slag, and } \mathrm{La}_{2} \mathrm{O}_{3} \text { to mold slag for } \mathrm{CC} \\
\text { production of LCAK steel }\end{array}$ & 1995 & 159 \\
\hline Zhang and Cai & $\begin{array}{l}\mathrm{La}_{2} \mathrm{O}_{3} \text { to ingot mold powder; } 17 \text { of } 28 \text { analyzed slag inclusions had the com } \\
\text { position of model power. }\end{array}$ & 1996 & 160 \\
\hline Racabois et al. & $\begin{array}{l}\text { La was added anto steel during steel refining after Al killing to study the origin } \\
\text { of silvers defects. }\end{array}$ & 2003 & 90 \\
\hline
\end{tabular}

Air is the most common source of reoxidation, which can enter ingot steel in many ways. (1) Molten steel mixes with air during teeming due to the strong turbulence. The major variables affecting this reoxidation mechanism are teeming speed, stream size, and shape. ${ }^{[78]}$ (3) Air is sucked into the molten steel at the connection between the ladle and trumpet. (4) Air penetrates into the steel from the top surface of the ingot during teeming or standing.

The exposure of molten steel to the atmosphere in this manner rapidly forms oxide films on the surface of the flowing liquid, which are folded into the liquid, forming weak planes of oxide particles in the solidified product. ${ }^{[166]}$ Severe reoxidation may cause surface scums or natural slags, and they are easily emulsified in regions of turbulence. This leads to internal inclusions, which may separate to interfaces between the slag/lining and steel. Thus, it is not unusual to see large macroinclusions, which contain both refractory materials and reoxidation products. Deoxidizing elements such as $\mathrm{Al}, \mathrm{Ca}$, and $\mathrm{Si}$ are preferentially oxidized by environmental oxygen, and their oxide products develop into nonmetallic inclusions generally one to two magnitudes larger than deoxidation inclusions. ${ }^{[167]}$ Severe reoxidation can form inclusions containing $\mathrm{FeO}$ and $\mathrm{MnO}$.

The best solution to prevent reoxidation is to limit the exposure of air to the casting process. Methods to protect the teeming stream in ingot casting practice can be classified into the following types: (1) shrouding by an inert gas curtain injected through a steel ring manifold or porous refractory ring around the teeming nozzle,$^{[168,169]}$ (2) using an intermediate shroud box seated on top of the trumpet with injection of inert gas either directly or through a porous refractory ring, (3) purging inert gas into the runner system and mold before teeming, ${ }^{[168,170]}$ and (4) carrying out teeming in vacuum. ${ }^{[171]}$

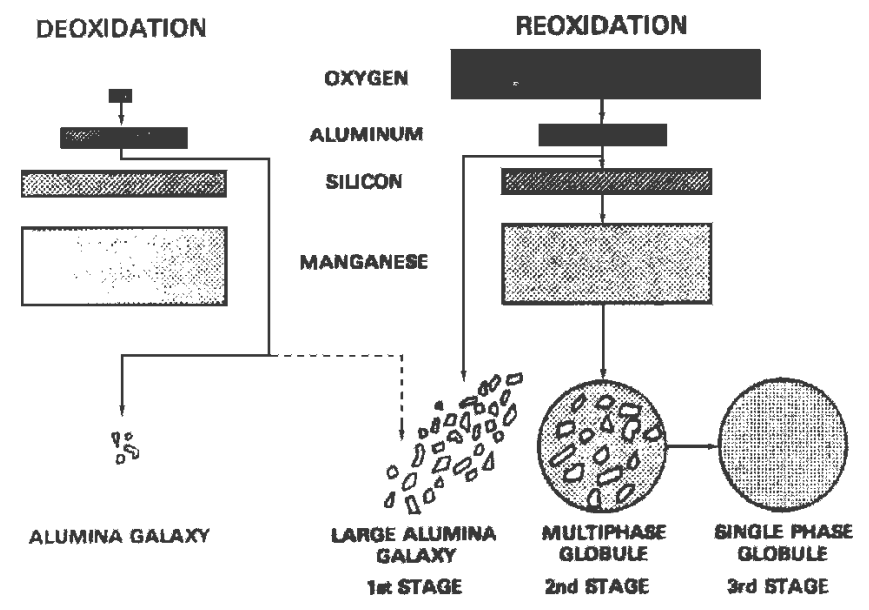

Fig. 23-The formation of inclusions in steels deoxidized with aluminum (based on Hilty ${ }^{[15]}$ ).

Argon is a much better inert gas to prevent reoxidation than carbon dioxide ${ }^{[170]}$ or nitrogen, which are subject to other detrimental reactions. ${ }^{[167,170]}$ Schlatter reviewed teeming stream protection systems for ingot casting, and evaluated sealing methods between teeming nozzle and trumpet, mold purging, and flooding the slide gate box with inert gas. ${ }^{[167]}$ Examples of effective sealing systems are detailed in Figure 24. ${ }^{[167]}$ Sealing was reported to lower the nitrogen content by $\sim 30 \mathrm{ppm}$ and hydrogen by $\sim 1 \mathrm{ppm}$, relative to nonsealed casting, and to considerably lower large nonmetallic $\mathrm{Al}_{2} \mathrm{O}_{3}$ clusters (Figure 25). ${ }^{[3]}$ Most significantly, sealing can improve bottom-poured ingot casting quality by lowering large inclusions, especially in the interior.

Another reoxidation source is $\mathrm{SiO}_{2}, \mathrm{FeO}$, and $\mathrm{MnO}$ in the slags and lining refractories. These oxides readily react with more powerful deoxidants such as aluminum within 


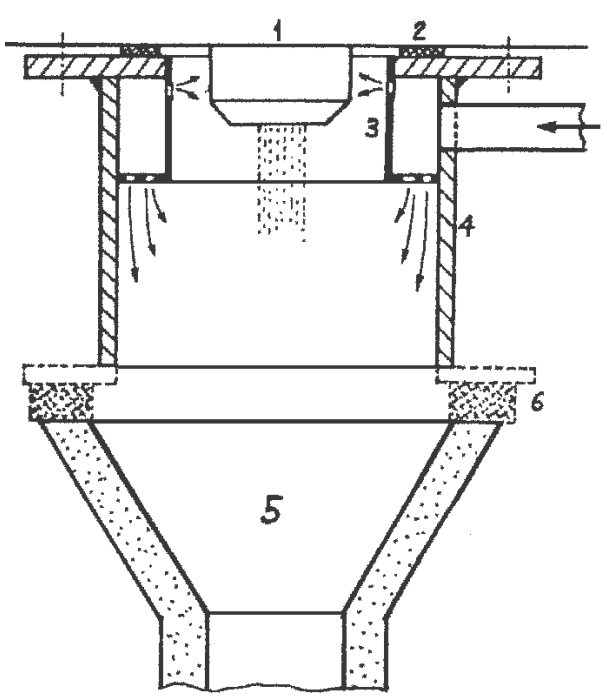

(a)

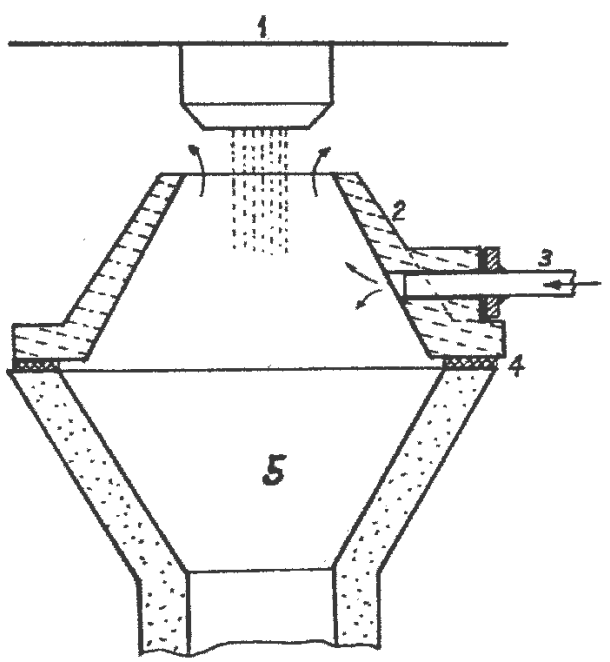

(c)

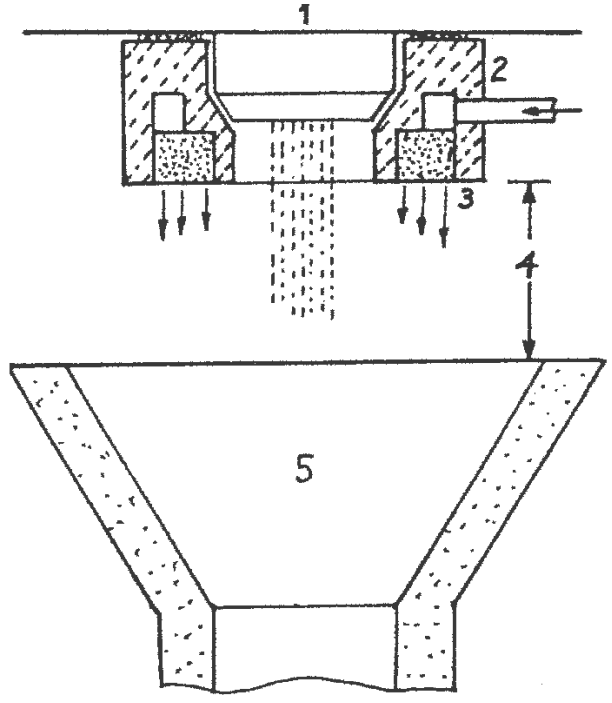

(b)

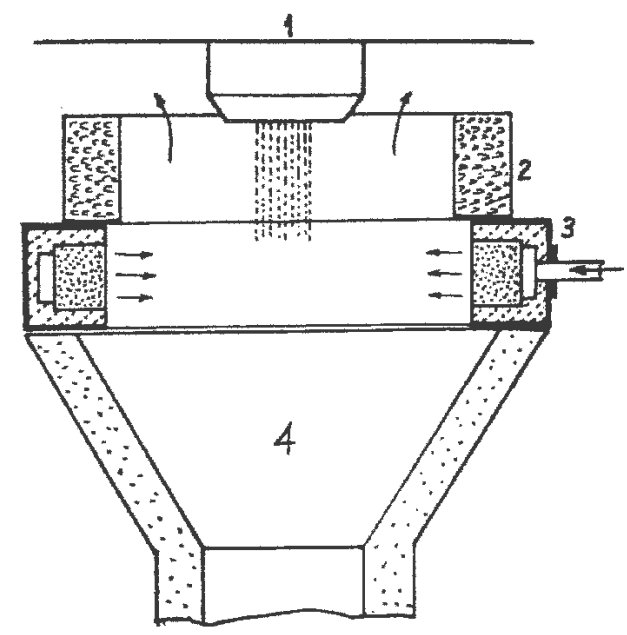

(d)

Fig. 24- (a) through $(d)$ Devices for stream protection from air absorption. ${ }^{[167]}$

the steel to grow inclusions near the slag or lining interface via the following reaction:

$$
\mathrm{SiO}_{2} / \mathrm{FeO} / \mathrm{MnO}+[\mathrm{Al}] \rightarrow[\mathrm{Si}] /[\mathrm{Fe}] /[\mathrm{Mn}]+\mathrm{Al}_{2} \mathrm{O}_{3}
$$

This leads to larger alumina inclusions with variable composition. This phenomenon further affects exogenous inclusions in the following ways. (1) This reaction can erode the surface of the lining, changing its shape to alter the fluid flow pattern near the lining walls and inducing further, accelerated lining erosion. (2) A large exogenous inclusion of broken lining or entrained slag can entrap small inclusions, such as deoxidation products, which may also act as a heterogeneous nucleus for further inclusion growth via precipitation. This complicates the composition of exogenous inclusions.

To prevent reoxidation from the slag or lining refractory, it is important to maintain a low $\mathrm{FeO}, \mathrm{MnO}$, and $\mathrm{SiO}_{2}$ content. It was reported that high $\mathrm{Al}_{2} \mathrm{O}_{3}$ or zirconia bricks containing low levels of free $\mathrm{SiO}_{2}$ are more suitable. ${ }^{[3]}$
Although high $\mathrm{Al}_{2} \mathrm{O}_{3}$ or basic bricks have good antierosion quality, they can combine with water in the refractory to cause blow holes in the ingot bottom unless they are first "burnt" or dried. ${ }^{[3]}$

\section{B. Slag Entrainment Mechanisms}

Mold powder is added to the top surface of the molten steel in the ingot to provide thermal insulation, protect from reoxidation, feed liquid flux into the mold shell gap for lubrication and uniform heat transfer, and assimilate any inclusions that may float. ${ }^{[172,173,174]}$ Without mold powder, an oxide scum forms on the surface of the metal as it rises in the mold. This is more prominent in steels containing aluminum and titanium, where the scum formed is heavy and viscous. The scum may attach to the mold wall and become entrapped by rising metal just below the ingot surface, giving rise to surface defects and subsurface inclusions. ${ }^{[175]}$ Refractories usually interact with the scum, which alters their mineralogical compositions by the end 


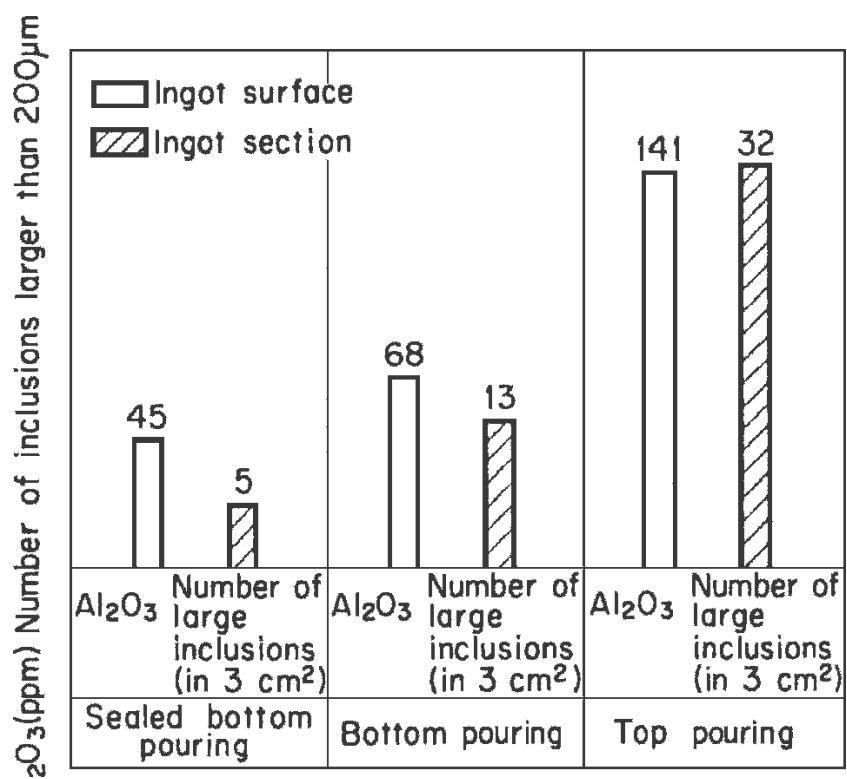

Fig. 25-Effect of argon sealing on alumina content and number of large inclusions in ingot. ${ }^{[3]}$

of casting, as shown in Figure $26 .{ }^{[176]}$ The scums contain other oxides in addition to alumina-silica, which are mainly components of the altered refractories. ${ }^{[122,176]}$

Any steelmaking operation involving turbulent mixing of slag and metal, especially during transfer between vessels, produces liquid slag particles suspended in the steel. ${ }^{[28,177]}$ Many liquid particles can coalesce and be removed by transport and floatation to the top surface and absorption into the slag. However, those which remain can nucleate further inclusions and interact chemically with refractories, giving rise to complex inclusions that contain both indigenous and exogenous material. Being liquid, slag inclusions are usually spherical, ${ }^{[29,47,178]}$ as shown in Figure 14. ${ }^{[29,47]}$

Emulsification of liquid slags or scums on the surface of liquid steels is one of the major sources of exogenous inclusions formation. ${ }^{[179]}$ Slag inclusions, 10 to $300 \mu \mathrm{m}$ in size, contain large amounts of $\mathrm{CaO}$ or $\mathrm{MgO}^{[78]}$ and are generally liquid at the temperature of molten steel, so are spherical in shape. Entrainment of slag occurs due to shear at the slag-metal interface caused by fluid flow, related to the submeniscus fluid velocity, the shear length (often related to slag depth), and the slag physical properties (density, viscosity, and surface tension). Emulsification of the slag layers that float on the top of molten steel in gas-stirred vessels has been extensively investigated. ${ }^{[180,181,182]}$ For the bottom pouring ingot casting process, slag entrainment into the molten steel in mold is affected mainly by the following: vortexing, method of powder addition, runner and ingate design, filling rate, turbulence at the meniscus, and slag properties.

\section{Vortex during steel pouring from a ladle}

Vortexing can entrain ladle slag into the molten steel, which then flows through trumpet and runner into the mold. Sankaranarayanan and Guthrie studied vortex formation during drainage using a water model of a ladle. ${ }^{[183]}$ They reported that the decrease in the liquid depth facilitates the
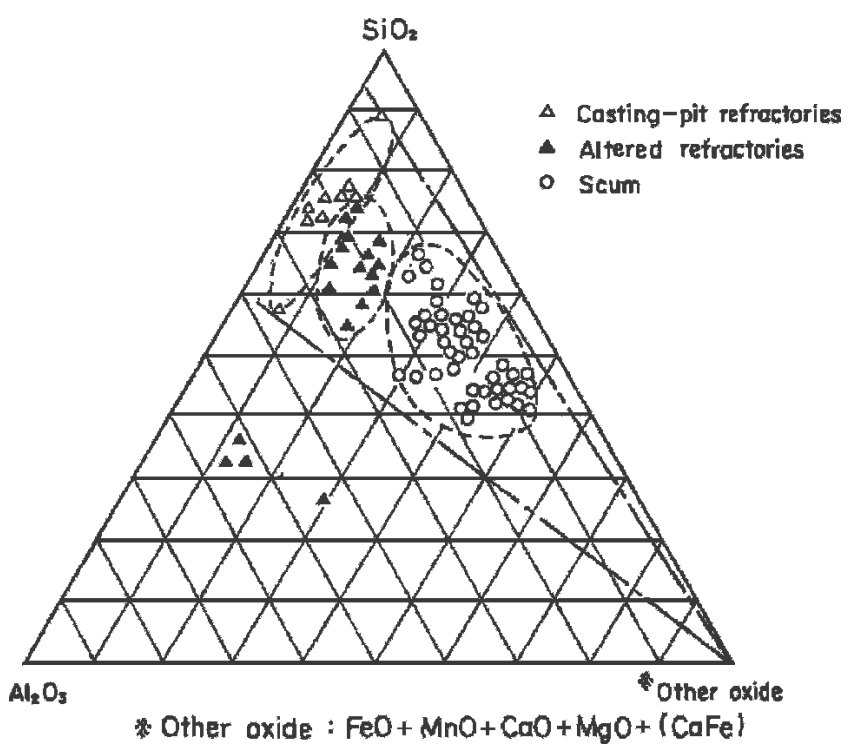

Fig. 26-Ternary composition of casting-pit refractories, altered refractories, and scums for bottom-teeming carbon steel. ${ }^{[176]}$

vortex formation. The rotational velocity components induced at the surface by the vortex significantly increase the critical depth. ${ }^{[183]}$ Manabu et al. documented the existence of a critical gas flow rate for entrainment in both a silicon oil-water and a slag-steel system. ${ }^{[184]}$ Slag depth, slag properties, and gas bubble diameter also play a role. ${ }^{[184]}$ This vortex can be avoided in many ways, such as shutting off pouring before the depth is too shallow, controlling the flow pattern, or inserting objects such as a stopper rod above the outlet to act as a vortex breaker.

\section{Method of the powder addition}

The best way to add the mold powder during bottom pouring is to suspend a bag containing the powder at an optimized distance such as $300 \mathrm{~mm}(12 \text { in. })^{[185,186]}$ above the ingot bottom before teeming, as shown in Figure 2. An alternative procedure is simply to drop the bag of powder into the ingot mold before the start of pouring, whereupon the incoming steel ruptures the bag and the powder distributes itself over the surface of the steel. In this method, however, the steel is prone to engulf the powder producing defects at the bottom of the ingot, as shown in Figure 27. Bartholomew et al. ${ }^{[186]}$ recommend use of "board flux." This board is placed flat on the mold bottom and minimizes splash while it floats on the rising meniscus, progressively breaking down into a flux, with the same properties as a powdered mold flux. Rejections on ingots using the board flux were 0.65 pct, while all other bottom pour ingots using powder fluxes had rejections of 1.90 pct. $^{[186]}$

\section{Runner and ingate design}

During the initial entry of steel into the mold, the momentum of the powerful inflow jet can spout upward into the mold and entrain mold powder, if the filling rate is too high. After the initial spout has settled into a flat top surface, the incoming jet of steel may still push the floating mold powder to the sides, creating a bare surface or "eye" above the ingate. Excessive turbulence at the slag metal interface is one of the causes of reoxidation and exogenous 
inclusions. When interfacial level fluctuations exceed a critical level, slag entrainment will take place just inside the mold. This effect can be decreased by optimizing the runner and ingate design that delivers metal into ingot in the mold cavity. ${ }^{[3,154,187-189]}$ The effect of the shape of the runner outlet (mold ingate) on the molten steel flow pattern in the mold was examined using a water model ${ }^{[3]}$ and numerical simulation. ${ }^{[189]}$ It was reported that in order to avoid

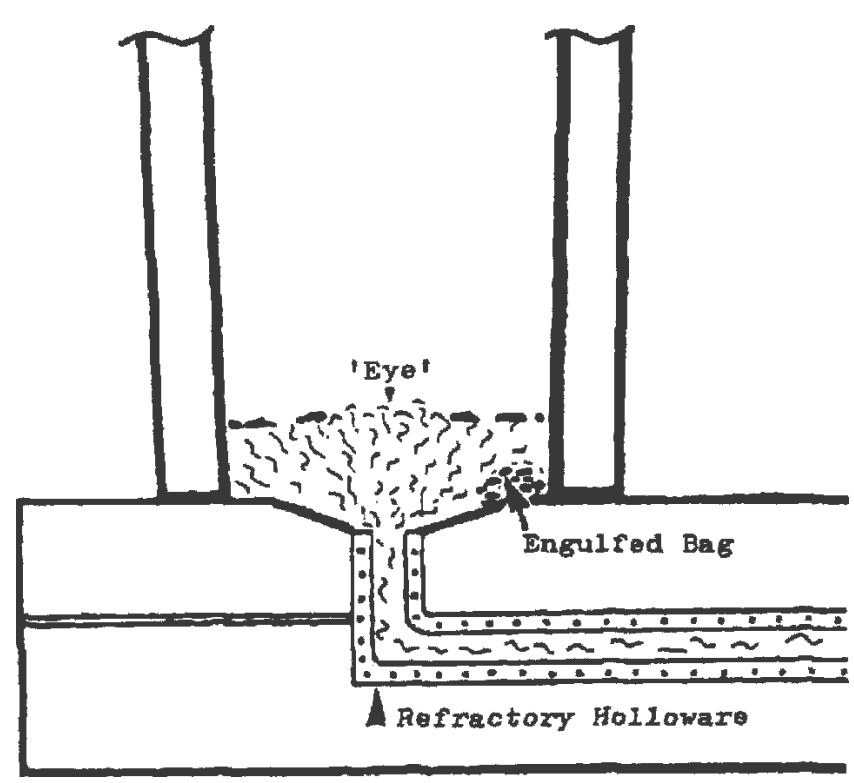

Fig. 27-Schematic of bottom pouring showing entrapment of powder added to the mold bottom in the bag. ${ }^{[85]}$ defected flow, the ratio of the linear length of the ingate to its minimum diameter should be larger than $6 .^{[3]}$ The direction and velocity of the inlet jet depends on the details of the ingate geometry. ${ }^{[187]}$ The flow of fluid from an upgate into a typical bottom-teemed ingot is shown in Figure 28. ${ }^{[189]}$ The recent computational results illustrate the great importance of ingate shape on the direction of the spout. The calculation of the fluid flow and inclusion trajectory in the runner indicates that inclusions tend to move along the top wall, ${ }^{[189,190,191]}$ so they might be trapped by weirs or inclusion-entrapment cavities near the end of runners. Using ceramic foam filters at the runner system near the ingate is another method to remove more inclusions before they enter the ingot mold. ${ }^{[164,192-194]}$

\section{Filling rate}

The filling rate is typically controlled to maintain the rate of rise of steel level in the ingot mold, between 0.2 and $0.3 \mathrm{~m} / \mathrm{min}$ ( 8 and $12 \mathrm{in.} / \mathrm{min}$ ). Large ingots, forging ingots or special designs, are usually filled slower, which is reportedly done to ensure forming a proper skin thickness to eliminate or minimize cracking. ${ }^{[186]}$ Ogurtsov studied the importance of the bottom pouring rate on ingot quality. ${ }^{[195]}$ Fast teeming speeds increase flux entrapment, ingot cracking, defects on the ingot bottom from steel surge, choking off the steel in the refractory runner system due to the high volume of steel entering the trumpet, and recurring defects called "teeming laps." ${ }^{[80]}$ On the other hand, slow teeming speeds give rise to lapping or rippling surface defects, crusting of the steel meniscus, freeze-off in the refractory runner system, and poor mold flux performance. The effect of the filling velocity through the ingate on the spout shape
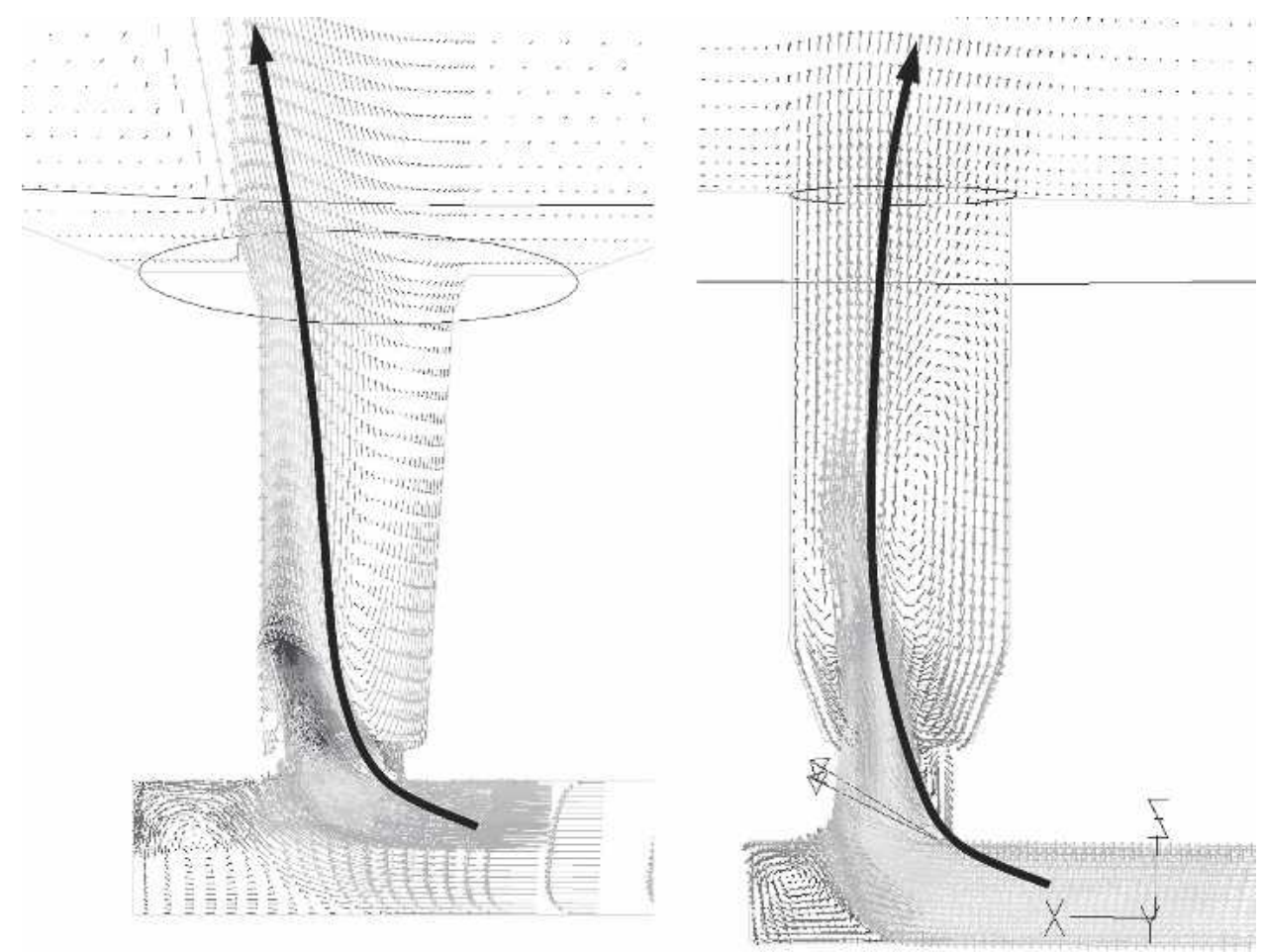

Fig. 28-Effect of upgate design on the fluid flow pattern into the ingot mold bottom during the bottom teeming process (left: upgate with taper; and right: upgate without taper). ${ }^{[189]}$ 
into the mold is shown in Figure 29. ${ }^{[191]}$ If the velocity is larger than the critical value, the metal column will enter the mold, and the steel will fall back under gravity, so slag entrainment and air absorption will take place. This critical velocity depends on steel surface tension and steel density according to Reference 196. $V_{\mathrm{Cr}}=3.5(\gamma / \rho)^{0.25}$, where typically $\gamma=1.89 \mathrm{~N} / \mathrm{m}, \rho=7020 \mathrm{~kg} / \mathrm{m}^{3}$, and $V_{\mathrm{Cr}}=0.45 \mathrm{~m} / \mathrm{s}$. The critical filling rate can be found from this critical velocity and the ingot geometry. It is recommended that the teeming rate is kept below this critical value during the first several minutes. After, it can be increased gradually when the molten steel in mold attains a reasonable height and a stable surface level.

\section{Turbulence at meniscus}

Fluctuations of the meniscus level caused by surface turbulence encourage entrainment of slag droplets into the steel, leading to inclusions. Such fluctuations also enhance reoxidation by bringing the steel interface in contact with the atmosphere, or by increasing the rate of interfacial chemical reactions, including the oxidation of aluminum in the steel by iron oxide in the slag.

\section{Slag properties such as interfacial tension}

Emulsification and slag entrainment are easier with lower interfacial tension, lower slag viscosity, and higher slag density (closer to steel). ${ }^{[197]}$ The interfacial tension between the steel and the molten casting powder determines the shape of the steel meniscus and the ease of flux entrainment. ${ }^{[185]}$ The height of meniscus $(h)$ depends on the interfacial tension $(\sigma)$, difference in density between the steel and the fused slag layer $(\Delta \rho)$, and acceleration rate $(g)$ by the following equation ${ }^{[185]}: h=[2 \sigma /(g \Delta \rho)]^{1 / 2}$. Specifically, an interfacial tension of $1.4 \mathrm{~N} / \mathrm{m}$ for a lime-silica-alumina slag in contact with pure iron generates a meniscus height
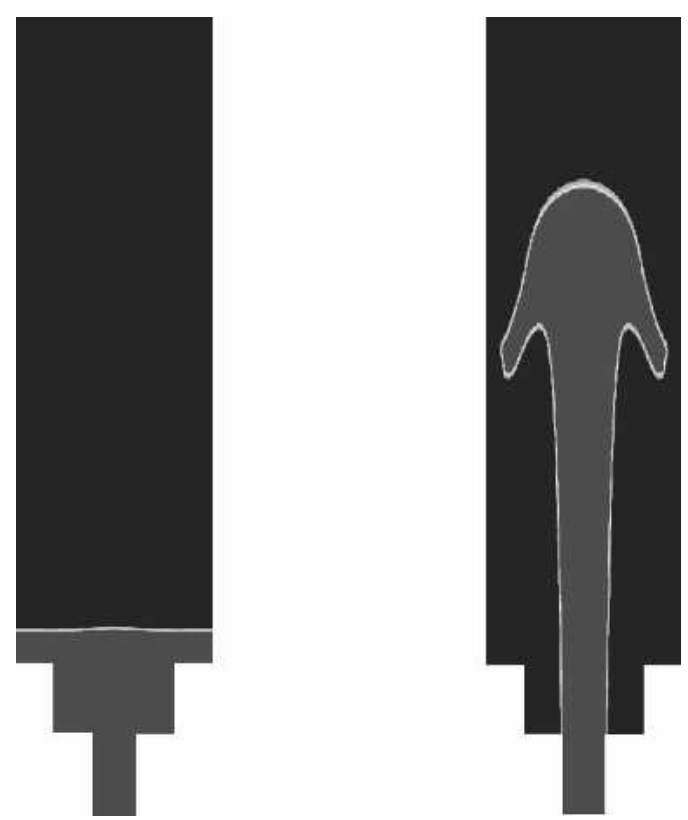

Fig. 29-Effect of teeming rate on the free surface of steel entering a bottom-poured 8 -in. ingot mold (left: $11.5 \mathrm{in} . / \mathrm{min}$ in ingot, and right: $503.2 \mathrm{in.} / \mathrm{min}$ in ingot). ${ }^{[191]}$ of about $8 \mathrm{~mm}(0.3 \mathrm{in}$.). The interfacial tension is greatly reduced by chemical reactions at the interface or when surface-active species such as sulfur are present. A very low local interfacial tension can produce surface tension gradients, which cause spontaneous fluid flow and turbulence at the interface through the Marangoni effect. Such turbulence might emulsify the interface and entrain slag inclusions into the steel. It should be mentioned that during molten steel sampling to investigate the steel cleanliness of an ingot, air absorption and slag entrainment may also take place, which has been investigated by Fuchs and Jonson ${ }^{[2]}$ and Dekkers et al. ${ }^{[53]}$ In addition, the use of board top compounds to prolong surface solidification time and lessen slag entrainment was reported. ${ }^{[186]}$

\section{Lining Refractory Erosion/Corrosion Mechanisms during Steel Pouring}

Exogeneous inclusions generated during steel pouring include well block sand, loose dirt, broken refractory brickwork, and ceramic lining particles. They are generally large and irregularly shaped, ${ }^{[18,88,122,198,199]}$ as shown in Figure 15. ${ }^{[18,88,93]}$ These detrimental inclusions are introduced mechanically or by chemical erosion and can completely impair the quality of an otherwise very clean steel. Erosion of refractories is a very common source of large exogenous inclusions, which are typically solid and based on the materials of the trumpet, runner, and mold themselves. Exogenous inclusions have been observed in ingot steel from runner erosion ${ }^{[199]}$ and as an ingot surface defect of floating slag patches from fluxed runner brick. ${ }^{[80]}$ In general, larger inclusions cause greater quality problems. The relative volumes of various inclusions can be taken as an index of their likely deleterious nature, as shown in Table V ${ }^{[28]}$ In this table, the relative volume is the volume of inclusions divided by the volume of the $5-\mu \mathrm{m}$ spherical inclusions. This clearly indicates that erosion products are likely to cause the most serious problems due to their large size. ${ }^{[28]}$ Almost 60 pct of all exogenous inclusions in killed steels are reported to arise from "attacking" or "fluxing" of refractories. ${ }^{[200]}$

Brick quality of both the trumpet and runners has a significant effect on steel quality. The results of corrosion tests on various brick materials with high manganese steel are illustrated in Figure 30. ${ }^{[3]}$ Erosion experiments that immersed lining samples into a melt (steel melt ${ }^{[148-151]}$ or

Table V. The Sizes and Relative Average Volumes of Various Inclusion Types ${ }^{[28]}$

\begin{tabular}{lcc}
\hline Type of Inclusions & Diameter $(\mu \mathrm{m})$ & Relative Volume \\
\hline $\begin{array}{l}\text { Alumina, spinel, and CaO } \\
\quad 6 \mathrm{Al}_{2} \mathrm{O}_{3} \text { (other than cluster) }\end{array}$ & 5 & 1 \\
$\begin{array}{l}\text { Other calcium aluminates } \\
\text { Secondary deoxidation }\end{array}$ & 27 & $\sim 160$ \\
$\quad$ products (Si-killed steel) & 32 & $\sim 260$ \\
$\begin{array}{l}\text { Primary deoxidation products } \\
\quad(\text { Si-killed steel) }\end{array}$ & 49 & $\sim 940$ \\
$\begin{array}{l}\text { Erosion silicates } \\
\quad(\text { Al-killed steel) }\end{array}$ & 64 & $\sim 2100$ \\
$\begin{array}{l}\text { Erosion silicates } \\
\quad(\text { Si-killed steel) }\end{array}$ & 107 & $\sim 9800$ \\
\end{tabular}


slag melt ${ }^{[89,152,153]}$ ) found that "glazed refractories" and "reaction layers at the surface of bricks" formed with molten steel at $1550{ }^{\circ} \mathrm{C}$ to $1600{ }^{\circ} \mathrm{C} \cdot{ }^{[151,153,200]}$ The compositions of manganese aluminosilicate inclusions $\left(\mathrm{MnO}-\mathrm{Al}_{2} \mathrm{O}_{3}-\mathrm{SiO}_{2}\right.$ system) found in forgings, ladle glaze analysis, and reaction layers formed between refractory and liquid steel are compared in Figure 31. ${ }^{[88]}$ In this figure, the liquid steel is killed mainly by silicon and manganese alloys and a small amount of aluminum. Thus, all deoxidation products contain more $\mathrm{SiO}_{2}$ and $\mathrm{MnO}$ than refractory and glaze attack product. The latter contain more alumina. It was reported that almost

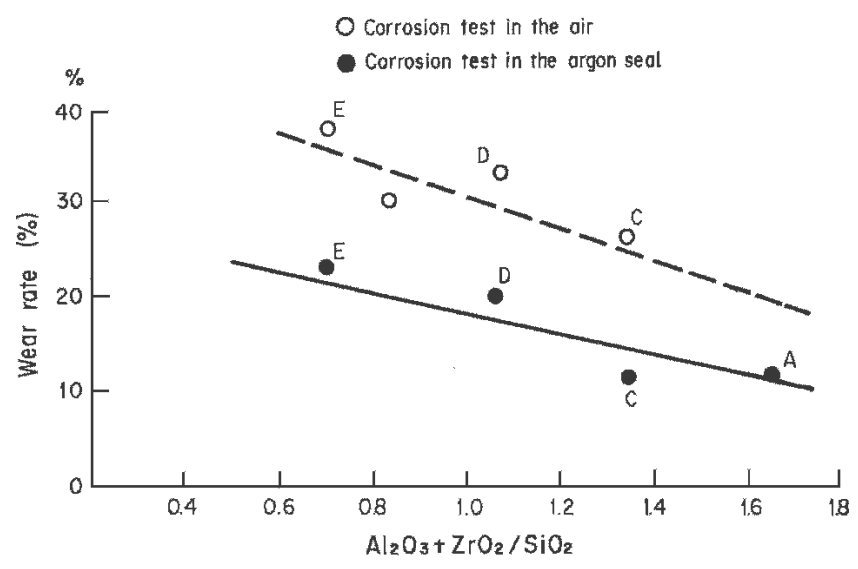

\begin{tabular}{|c|c|c|c|}
\hline \multirow{2}{*}{$\begin{array}{l}\text { Material } \\
\text { of brick }\end{array}$} & \multicolumn{3}{|c|}{$\begin{array}{l}\text { Chernical } \\
\text { Compositiont\% }\end{array}$} \\
\hline & $\mathrm{SIO}_{2}$ & $\mathrm{Al}_{2} \mathrm{O}$ & $\mathrm{ZrO}_{2}$ \\
\hline 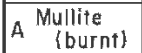 & $36 .^{7}$ & $60^{\circ}$ & - \\
\hline B $\begin{array}{c}\text { Chamotte } \\
\text { (unburnt) }\end{array}$ & $48 .^{\circ}$ & $40^{6}$ & - \\
\hline c Semizircon & $40 .^{7}$ & $139^{9}$ & $40^{6}$ \\
\hline $\begin{array}{c}\text { Chamatte } \\
\text { (burnt) }\end{array}$ & $45^{\circ}$ & $47 . .^{2}$ & \\
\hline$E \begin{array}{c}\text { Chamotte } \\
\text { (burnt) }\end{array}$ & $54^{9}$ & $38^{\circ}$ & - \\
\hline
\end{tabular}

Fig. 30-Effect of brick materials on wear rate (high manganese steel). ${ }^{[3]}$

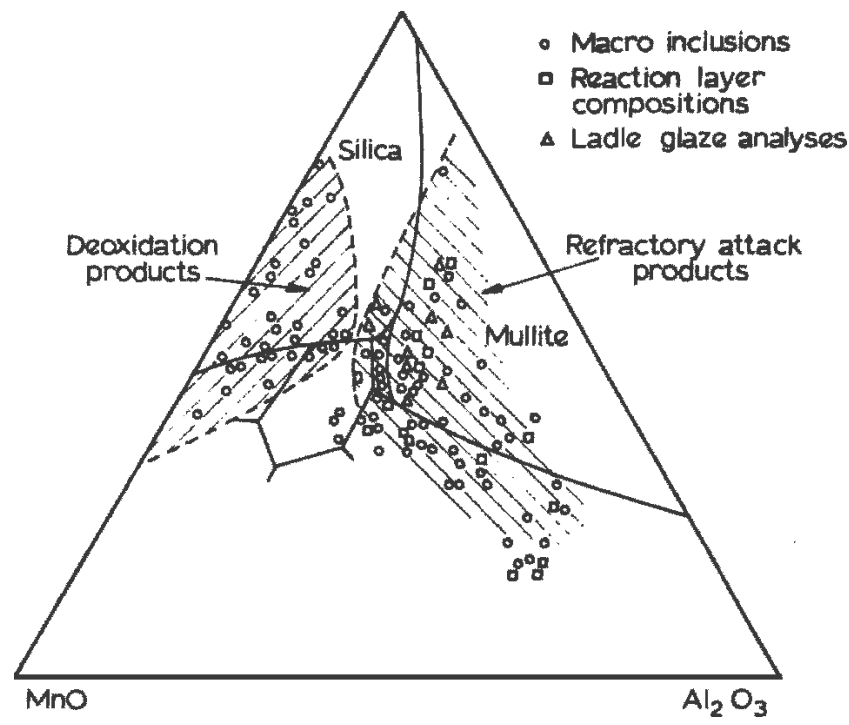

Fig. 31-Ternary composition of manganese aluminosilicate $\left(\mathrm{MnO}-\mathrm{Al}_{2} \mathrm{O}_{3^{-}}\right.$ $\mathrm{SiO}_{2}$ system) found in forgings, ladle glaze analysis, and reaction layers formed between refractory and liquid steel. ${ }^{[88]}$ all of the inclusions in a tool steel ingot originated as oxides from the erosion of the ladle glaze, and the amount of inclusions increased with ladle age (number of heats ladle being used). ${ }^{[201-203]}$

The interface between K1040 Al-killed steel and runner refractory is examined in Figure 32. ${ }^{[78]}$ The metal prills are believed to occur during teeming due to turbulence and mixing. Alumina from deoxidation products has apparently become integrated with the refractory, forming a composition gradient across the interface. Large inclusion clogs on the surface of the lining can also be released into the molten steel. Figure 33 shows the sand buildup at the ladle side wall. ${ }^{[86]}$ The sand is added at the well of the ladle bottom, i.e., the top of the shroud nozzle, before staring pouring. Part of the sand may be sintered there due to the high temperature of the molten steel, alumina inclusions attached there, and possible chemical reactions of the refractories. The sand buildup may exist there even after pouring. It was reported that some erosion products also contain alumina. In laboratory experiments, mullite may arise from reaction with aluminum. Usually, alumina is produced by erosion reactions, forming corundum in the surface layers of aluminosilicate refractories, particularly at low pressure. ${ }^{[28]}$

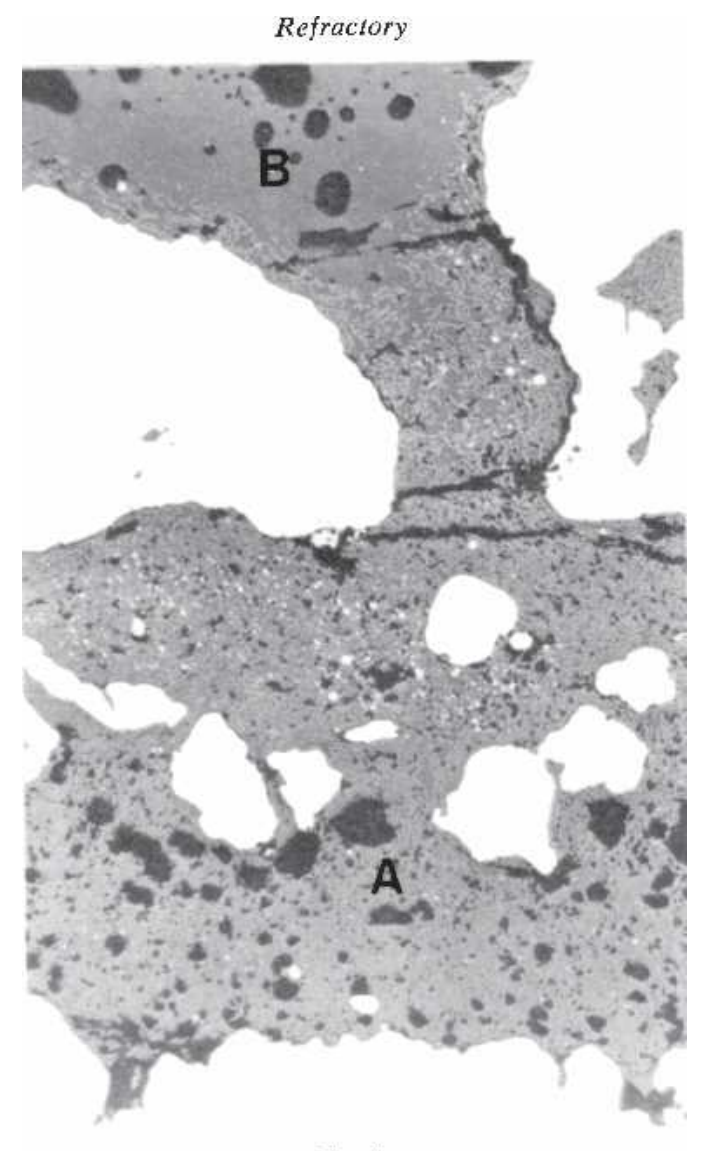

Steel

Fig. 32-Microstructure of the refractory/steel interface in a bottom-pour runner sample from K1040-type steel (unetched, white regions are metal prills ${ }^{[78]}$ ): (A) $\mathrm{Na}_{2} \mathrm{O} 0.5$ pct, $\mathrm{MgO} 0.8$ pct, $\mathrm{Al}_{2} \mathrm{O}_{3} 66.5$ pct, $\mathrm{SiO}_{2} 21.1$ pct, $\mathrm{K}_{2} \mathrm{O} 2.1$ pct, $\mathrm{CaO} 0.2$ pct, $\mathrm{TiO}_{2} 0.5$ pct, $\mathrm{MnO} 7.2$ pct, $\mathrm{FeO} 1.3$ pct; and (B) (primary matrix) $\mathrm{Na}_{2} \mathrm{O} 0.3$ pct, $\mathrm{MgO} 1$ pct, $\mathrm{Al}_{2} \mathrm{O}_{3} 35.7$ pct, $\mathrm{SiO}_{2} 54.2$ pct, $\mathrm{K}_{2} \mathrm{O} 2.9$ pct, $\mathrm{CaO} 0.2$ pct, $\mathrm{TiO}_{2} 1$ pct, $\mathrm{MnO} 3.2$ pct, $\mathrm{FeO} 1.5$ pct. 
Lining erosion generally occurs at areas of turbulent flow, especially when combined with reoxidation, high pouring temperatures, and chemical reactions. A typical defect from runner erosion is shown in Figure 34(a) ${ }^{[28]}$ It is clear that when refractory erosion problems are likely, particular attention should be paid to the quality of the bricks. ${ }^{[28]}$ The following parameters strongly affect lining erosion. (1) Some steel grades are quite corrosive (such as high-manganese steel or semikilled grades with high soluble oxygen contents) and attack trumpet lining, runner bricks, mold insulation boards of ingot systems, or the binder and mold sands of foundry systems, leading to large

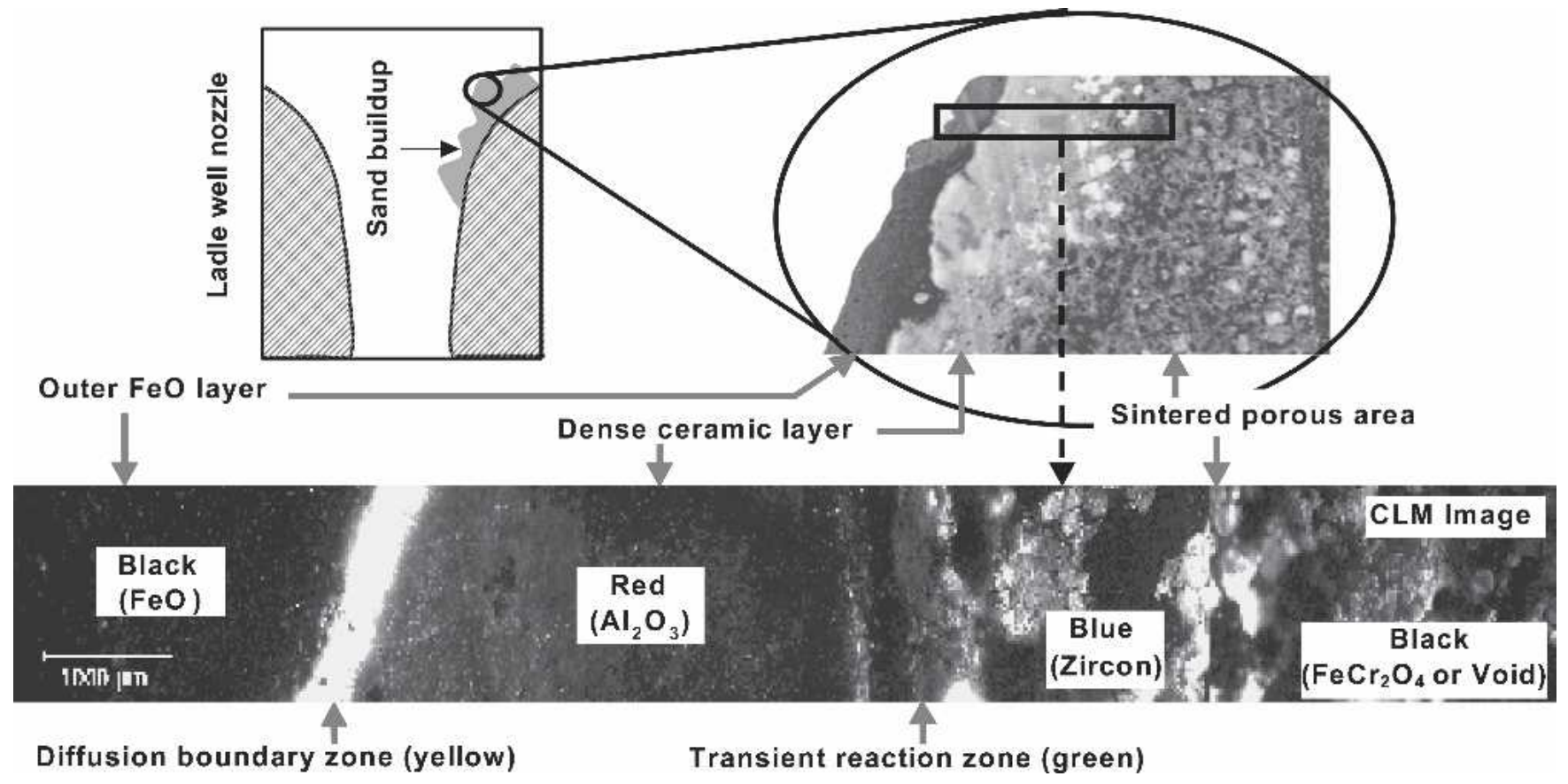

Fig. 33-Ladle sand buildup block. ${ }^{[86]}$
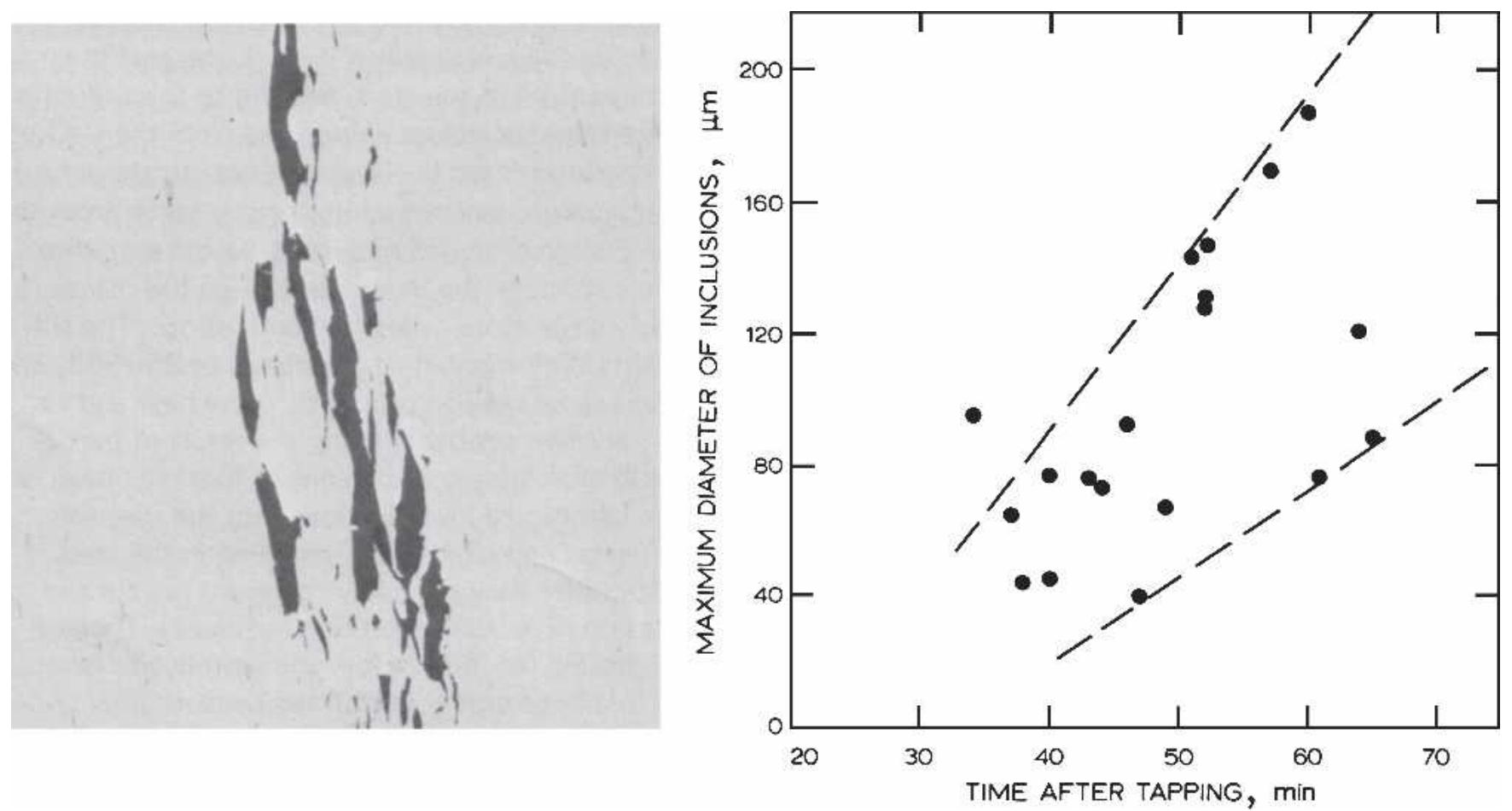

Fig. 34-Defect from runner erosion: ${ }^{[28]}(a)$ group of silicates from feeder-head titles in rolled billet; and $(b)$ increase of maximum size of eroded silicates during teeming. 
entrapped particles. (2) Manganese oxide preferentially attacks the silica-containing portions of the refractory. High-purity (expensive) $\mathrm{Al}_{2} \mathrm{O}_{3}$ and $\mathrm{ZrO}_{2}$ refractories can better withstand $\mathrm{MnO}$ slag or high-Mn steel. ${ }^{[3,148]}$ (3) Iron-oxide-based inclusions are very reactive and wet the lining materials, leading to erosion of the mold in regions of high turbulence. To avoid $\mathrm{FeO}$, oxygen should be minimized by fully killing the steel with a strong deoxidant such as $\mathrm{Al}$ or $\mathrm{Ca}$ and by preventing air absorption and other reoxidation sources. (4) The dissolved aluminum in steel can reduce the $\mathrm{SiO}_{2}$ in lining refractory to form exogenous alumina inclusions via Eq. [1]; therefore, aluminosilicates such as fireclay bricks $\left(>60\right.$ pet $\mathrm{Al}_{2} \mathrm{O}_{3},>30$ pet $\mathrm{SiO}_{2}$ ) should be avoided in the runners of bottom-poured ingots of high-Mn and high-Al steels. ${ }^{[28,154]}$ (5) Excessive velocity of molten steel along the trumpet and runner walls increases erosion/corrosion problems and the resulting macroinclusions. Running systems should be designed to keep the shear velocity less than $1.0 \mathrm{~m} / \mathrm{s}^{[154]}$ and in order to minimize agitation of the metal stream. Fast filling of the mold with low-velocity ingates minimizes erosion. One example is the use of the multiple ingate systems. ${ }^{[154]}$ (6) Excessive time of contact or filling and high temperature worsens erosion problems. Although it helps to float out inclusions, a longer holding time in the ladle tends to increase erosion of the ladle lining by the steel. Figure 34(b) shows that erosion products increase in size as teeming progresses or with prolonged teeming times. In this figure, the maximum diameter of the inclusions is the diameter of eroded silicate inclusions. Solutions include higher stability refractories, dense wear-resistant refractory inserts for high flow areas, and preventing reoxidation. ${ }^{[28]}$

\section{Chemical Reaction Mechanisms}

Chemical reactions produce oxides from inclusion modification, such as when $\mathrm{Ca}$ treatment is improperly performed. ${ }^{[6,9,204-206]}$ Identifying the source is not always easy, because it may not be unique. For example, inclusions containing $\mathrm{CaO}$ may also originate from entrained slag in addition to added the CaSi wire during calcium treatment. ${ }^{[204]}$

\section{INCLUSION AGGLOMERATION AND CLOGGING DURING STEEL POURING}

The agglomeration of solid inclusions can occur on any surface, including lining refractory walls and bubble surfaces, as shown in Figure 22. This "clogging" process is greatly affected by surface tension and temperature effects. The high contact angle of alumina in liquid steel (134 to $146 \mathrm{deg}$ ) encourages an inclusion to attach to refractory, in order to minimize its contact with steel. Alumina sintering takes place at temperatures above $1530{ }^{\circ} \mathrm{C} \cdot{ }^{[30,68,207]}$ When the temperature is lower that the sintering temperature, solid inclusions precipitate. The effect of contact angle, particle radius, and ferrostatic pressure on the strength of an agglomeration is shown in Figure $35 .{ }^{[32]}$ Due to collision and agglomeration, inclusions in steel tend to grow with increasing time ${ }^{[30]}$ and temperature (Figure 7). ${ }^{[19]}$

Inclusion growth by collision, agglomeration, and coagulation was investigated during ingot casting by many researchers. ${ }^{[19,69,70]}$ Miki et al. observed $\mathrm{SiO}_{2}$ inclusion

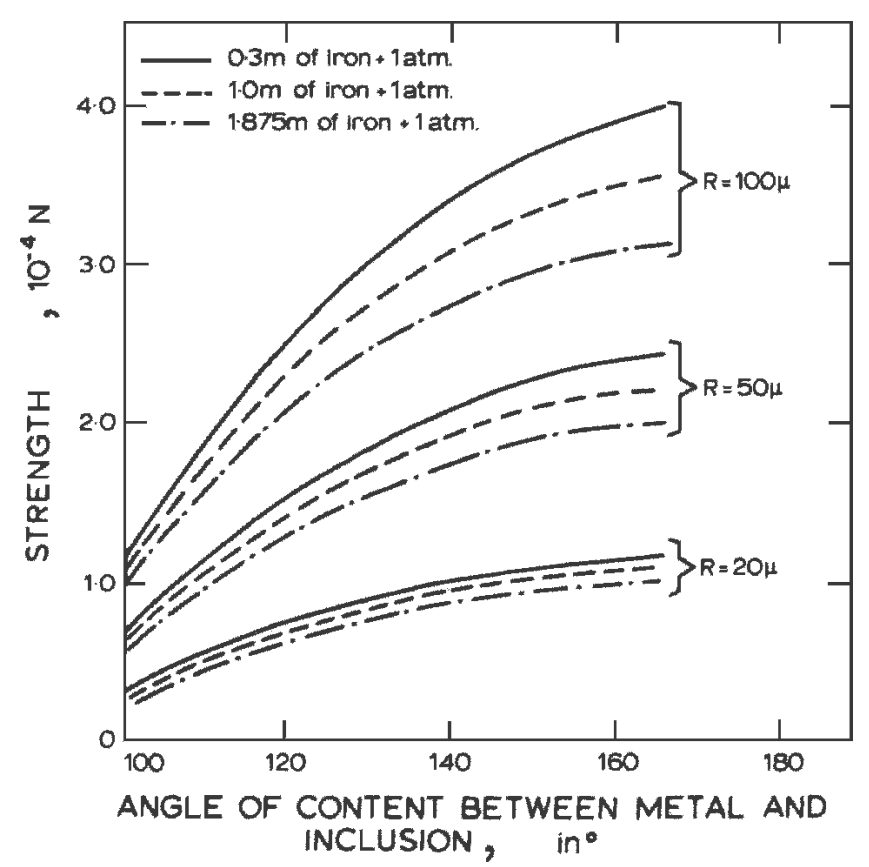

Fig. 35-Effect of the angle of contact, radius, and pressure on the strength of two solid particles immersed in liquid steel. ${ }^{[32]}$

growth by collision in a $10-\mathrm{kg} \mathrm{Si} / \mathrm{Mn}$ deoxidized steel ingot in a alumina crucible and stirred by electromagnetic field (Figure 9) ${ }^{[70]}$ Ooi et al. investigated alumina cluster inclusions in a 20-kg Al-killed steel ingot in an induction-stirred crucible (Figure 7). ${ }^{[19]}$ Aritomi and Gunji found dendritic inclusion formation on a spherical primary silica in Fe-10 pct Ni alloy deoxidized with silicon (Figure 36). ${ }^{[69]}$ Several models simulate inclusion growth by collision, including recent studies by Zhang et al., which also include inclusion nucleation starting from deoxidant addition. ${ }^{[25,26]}$ The fundamentals of alumina sintering into clusters ${ }^{[30,68,207]}$ need further investigation, though fractal theory has been used to describe the cluster morphology (features). ${ }^{[208,209]}$

Inclusion agglomeration can cause clogging problems in both nozzles and ingot runners. An example is shown in Figures $37(a)^{[17]}$ and $(b)^{[18]}$ of alumina inclusions clogging a submerged entry nozzle in continuous casting. Cures for this problem include improving steel cleanliness by improving ladle practices, using smooth, nonreacting refractories, and controlling fluid flow to ensure a smooth flow pattern. In 1949, Snow and Shea found $\mathrm{Al}_{2} \mathrm{O}_{3}$ covering the bore surface of nozzles used to teem Al-killed steel ingots. ${ }^{[210]}$ Duderstadt et al. ${ }^{[211]}$ found that nozzle blockage contained high levels of $\mathrm{Al}(0.0036 \mathrm{pct})$ and that nozzle sectioning revealed dendritic growth of alumina from the nozzle wall onto the bore. Farrell and Hilty ${ }^{[212]}$ observed clogs of $\mathrm{Al}, \mathrm{Zr}, \mathrm{Ti}$, and rare earth metals. Many other researchers experimentally investigated nozzle clogging by alumina inclusions in steel, such as Schwerdtfeger and Schrewe, ${ }^{[213]}$ Steinmetz and Lindberg, ${ }^{[214]}$ Saxena et al. ${ }^{[215]}$ Byrne and Cramb, ${ }^{[83-85]}$ Dawson, ${ }^{[216]}$ Fukuda et al., ${ }^{[217]}$ Tiekink et al., ${ }^{[218]}$ Tsujino et al., ${ }^{[150]}$ Ichikawa et al., and ${ }^{[219]}$ Fuhr et al. ${ }^{[220]}$ The cause and the main recommendation to avoid clogging was extensively reviewed by Kemeny ${ }^{[221]}$ and Thomas. ${ }^{[222]}$ 


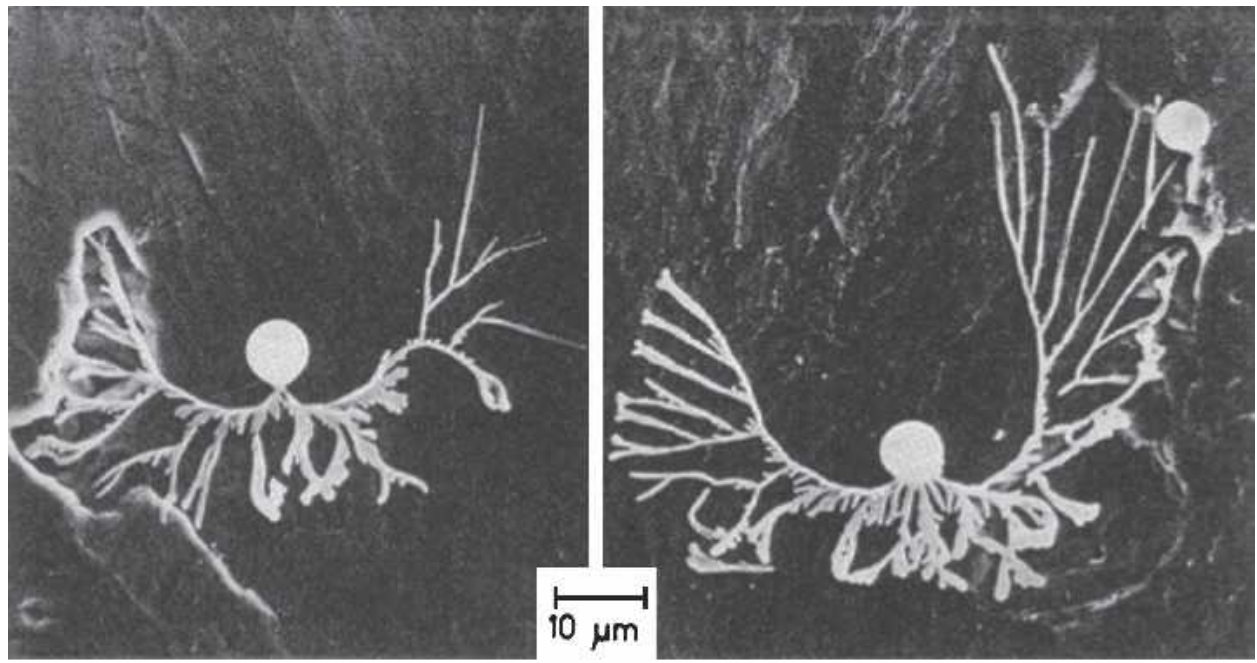

(a)

(b)

Fig. 36- (a) and (b) Dendritic inclusions formed from a spherical primary silica in Fe-10 pct Ni alloy deoxidized with silicon (inclusions in ingot). ${ }^{[69]}$

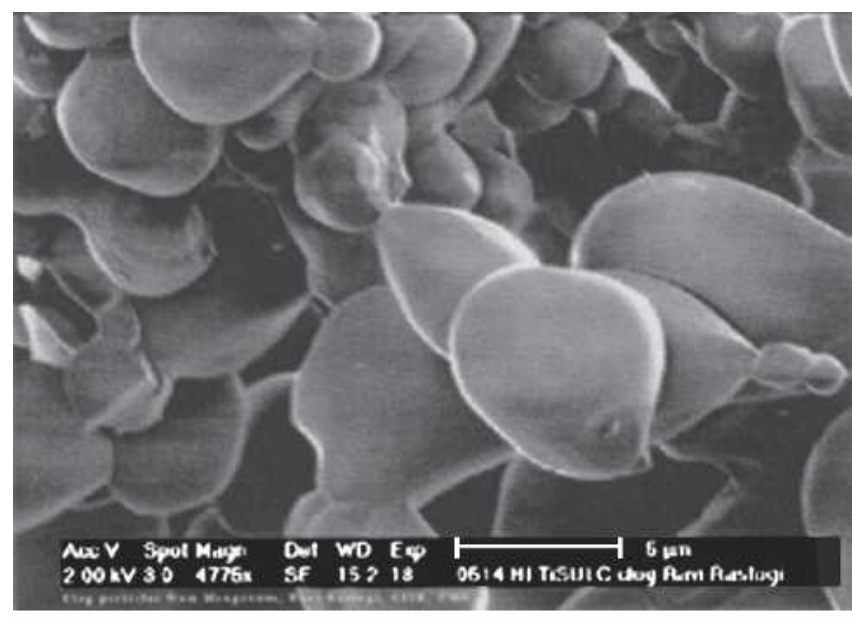

(a)

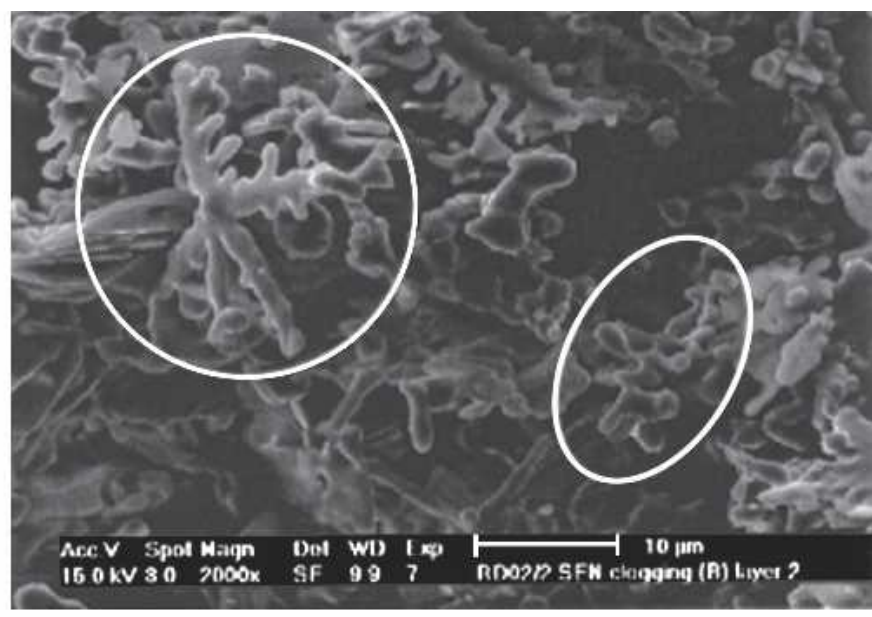

(b)

Fig. 37-Alumina clogs at the submerged entry nozzle during continuous casting of low-carbon Al-killed steel: (a) alumina inclusions clogged ${ }^{[17]}$ and (b) dendritic cluster and platelike clusters clogs. ${ }^{[18]}$

\section{INCLUSION TRANSPORT AND CAPTURE IN INGOT CASTING}

Inclusion motion and particle entrapment depend on fluid flow, heat transfer, and solidification of steel in the ingot. These phenomena in turn depend on teeming rate, runner outlet shape, ingot dimensions (height, thickness, width, taper, and height-thickness ratio), wall lining refractory, and mold top slag. ${ }^{[3]}$ Mathematical models of fluid flow and heat transfer are extensively used in steel search. ${ }^{[23-229]}$ Table VI summarizes physical ${ }^{[230]}$ and mathematical modeling studies of fluid flow, heat transfer, solidification, and particle motion during ingot mold filling. In these studies of plate-shaped or small foundry ingots, the $K-\varepsilon$ twoequation model is used to model turbulence, and the VOF model ${ }^{[231,232]}$ is used to simulate the top surface rising during mold filling. Example results in Figure 29 show that the detrimental spout of excessive filling rate, compared with the flat surface of gradual filling, presumably would generate fewer inclusion defects. Studies of three-dimensional fluid flow, heat transfer, solidification, and particle motion during mold filling for a large steel ingot are rare.

Many studies of segregation during ingot solidification have been reported. The well-known internal defects of $\mathrm{V}$ and inverse- $\mathrm{V}$ segregation (as shown in Figure $38^{[233]}$ ), central porosity, and internal inclusions are affected by fluid flow, heat transfer, solute transport, and ingot shape. Delorme et al. ${ }^{[234]}$ extensively studied the solidification of large forging ingots, segregation, and macroinclusions in ingots. ${ }^{[234]}$ Tsuchida et al. investigated the influence of ingot shape and composition on inverse- $\mathrm{V}$ segregation in 5 to $40 \mathrm{t}$ Al-killed steel ingots. ${ }^{[235]}$ Moore and Shah reviewed theories of $\mathrm{V}$ and inverse- $\mathrm{V}$ segregation and noted the importance of interactions among fluid flow, heat transfer, and composition. ${ }^{[233]}$ Ohnaka and Matsumoto simulated macrosegregation directly in ingots. ${ }^{[236]}$ Porosity is often 
Table VI. Fluid Flow Investigation during the Mold Filling Process by Different Researchers

\begin{tabular}{|c|c|c|c|}
\hline Author & Main Content & Year & Reference \\
\hline Van Der Graaf et al. & $\begin{array}{l}\text { snapshots and free surface pattern of filling process of iron and aluminum } \\
\text { in a plate cavity } \\
\text { water model study (PIV measurement) } \\
\text { 3-D fluid flow simulation of water by Flow-3D (VOF model for moving } \\
\text { fre surface modeling) }\end{array}$ & 2001 & 266 \\
\hline Hong et al. & 3-D fluid flow simulation (VOF model for moving free surface modeling) & 2001 & 267 \\
\hline Lin & $\begin{array}{l}\text { 2-D fluid flow, heat transfer and solidification simulation (VOF model for } \\
\text { moving free surface modeling) }\end{array}$ & 1999 & 268 \\
\hline Yuan et al. & $\begin{array}{l}\text { 3-D fluid flow, heat transfer and solidification simulation (VOF model for } \\
\text { moving free surface modeling) and temperature measurement in thin } \\
\text { plate filling process }\end{array}$ & 1997 & 269 \\
\hline $\mathrm{Xu}$ & $\begin{array}{l}\text { 2-D fluid flow, heat transfer (VOF model for moving free surface } \\
\text { modeling) and visualization of flow pattern in a water model of a thin } \\
\text { plate filling process }\end{array}$ & 1994, 1996 & 232230 \\
\hline Xue et al. & $\begin{array}{l}\text { 3-D fluid flow simulation (VOF model for moving free surface modeling) } \\
\text { and visualization of flow pattern in a water model of platelike square } \\
\text { ingot filling process }\end{array}$ & 1993 & 270 \\
\hline Xue et al. & $\begin{array}{l}\text { water model study of flow pattern; particle motion in a platelike ingot } \\
\text { filling process with different gate designs }\end{array}$ & 1993 & 271 \\
\hline Jong et al. & $\begin{array}{l}\text { measurement of flow pattern for a plate ingot or large square ingot filling } \\
\text { process }\end{array}$ & 1991 & 272 \\
\hline Mishima and Szekely & $\begin{array}{l}\text { 2-D fluid flow and heat-transfer simulation (VOF model for moving free } \\
\text { surface modeling) in the mold filling of a round ingot }\end{array}$ & 1989 & 273 \\
\hline Davidson et al. & 2-D flow transition in vacum arc remelting & 2000 & 274 \\
\hline Eriksson & $\begin{array}{l}\text { 2-D water model velocity measurement in an ingot during the bottom } \\
\text { pouring process }\end{array}$ & 2001 & 119 \\
\hline & 2-D numerical simulation of fluid in a bottom teeming ingot & 2004 & 188 \\
\hline Zhang and Thomas & $\begin{array}{l}\text { 3-D fluid flow, inclusion motion, and free surface fluctuation during the } \\
\text { bottom teeming process of a steel ingot }\end{array}$ & 2002-2004 & 189 to 191 \\
\hline
\end{tabular}

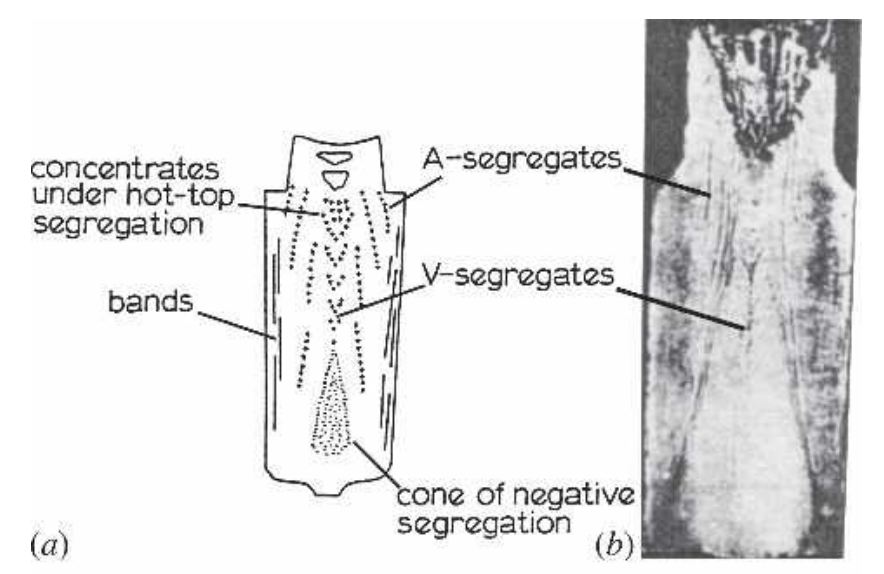

\section{a schematic representation (+ denotes posi- tive segregation and - negative segregation); $b$ sulphur print ${ }^{2}$}

Fig. 38-(a) and (b) Segregations in cast steel ingot. ${ }^{[233]}$

found in the center of forging ingots together with " $\mathrm{V}$ " segregation. ${ }^{[237,238]}$ Many researchers have correlated porosity with temperature gradient and solidification rate. Yamada et al. related porosity to the height-to-width ratio of the semisolid region formed during solidification of the ingot center. ${ }^{[237]}$ Beckermann et al. modeled both $\mathrm{V}$ and inverse segregation including crystal motion. ${ }^{[239,240]}$ Thomas et al. modeled heat flow and stress in steel ingot casting to investigate panel crack formation. ${ }^{[241,242,243]}$ Flemings $^{[244]}$ and Beckermann ${ }^{[239]}$ extensively reviewed macrosegregation in steel. Maheshwari et al. ${ }^{[152]}$ and Deng ${ }^{[245]}$ related the inclusion distribution in ingots to segregation. Zhul'ev and Zyuban investigated the effect of process parameters in the casting of large forging ingots on the formation of the optimum structure in the axial zone. ${ }^{[246]}$ Tyurin et al. studied the macrostructure of large forging ingots $(\sim 450 \mathrm{~mm}$ in diameter and $>2000 \mathrm{~mm}$ in length). ${ }^{[247]}$ Figure 39 shows the simulated 2-D fluid flow pattern and macrosegregation in a $\mathrm{Fe}-0.19$ pct $\mathrm{C}$ ingot. ${ }^{[236]}$ Figure 40 compares the solidification of conventional ingot melting and the electric slag remelting process. ${ }^{[248]}$ These figures show how the interior of conventional ingots is prone to trapping liquid in the central region, which is responsible for porosity, internal inclusions, and other problems.

Inclusion distribution in an ingot is affected by fluid flow, heat transfer, and solidification of the steel. A popular index for inclusion entrapment is the critical advancing velocity of the solidification front, which is affected by inclusion shape, density, surface energy, thermal conductivity, cooling rate (solidification rate $\mathrm{e}^{[122]}$, drag and interfacial forces, ${ }^{[139,249-252]}$ and protruding conditions of the solidification front. ${ }^{[122]}$ The probability of entrapment decreases with increasing solidification time (slower solidification rates), less segregation, and smaller protrusion on the solidification front. ${ }^{[122]}$ The dendrite arm spacing, cross-flow velocity, ${ }^{[253]}$ and the surface tension have significant effects on the entrapment of inclusions, related to the phenomenon 

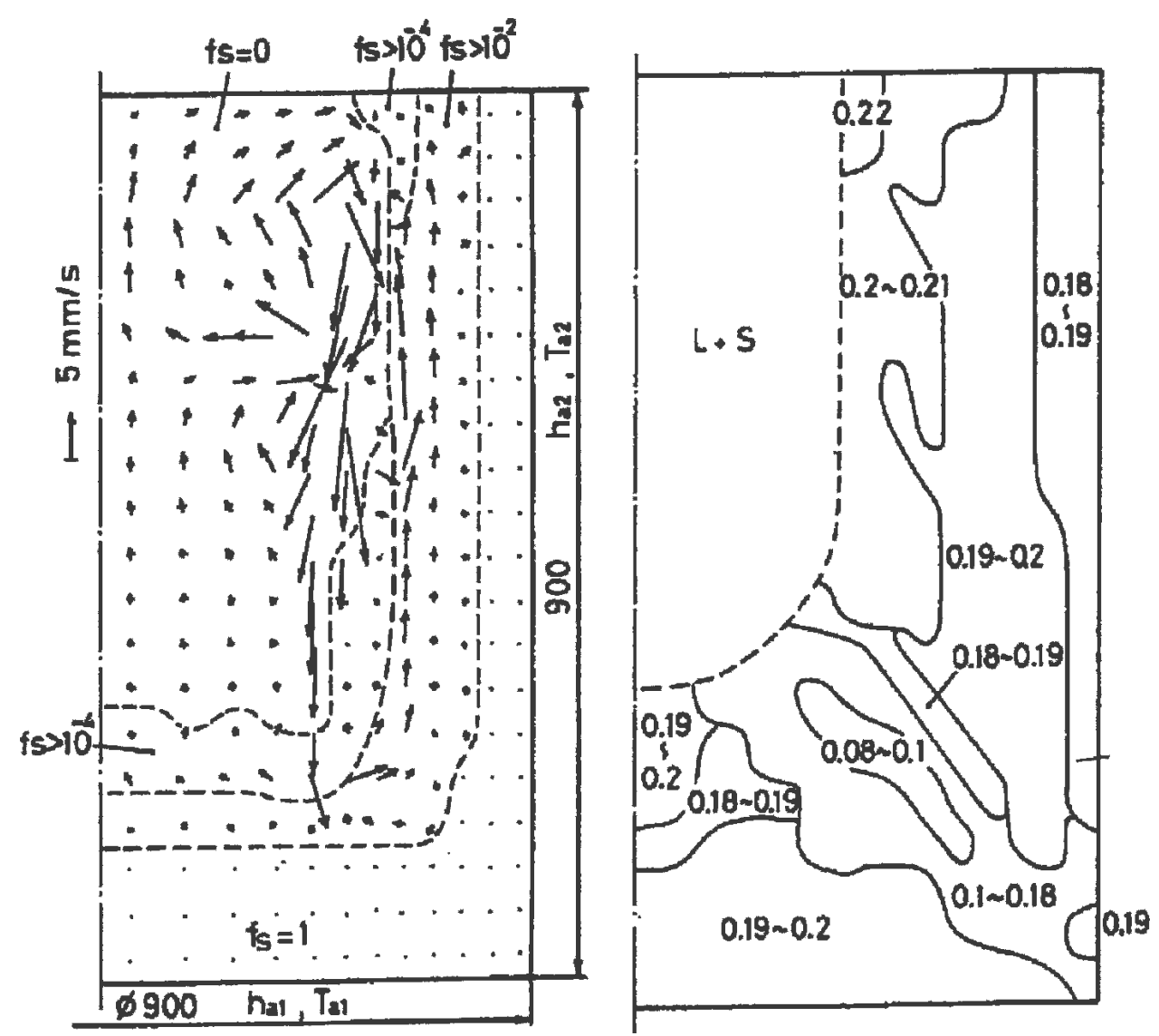

Fig. 39-Simulated fluid flow at $800 \mathrm{sec}$ and macrosegregation at $3800 \mathrm{sec}$ (numbers indicate carbon concentration in mass pct) in a Fe-0.19 pct C ingot. ${ }^{\text {[236] }}$

of pushing, engulfment, or entrapment. ${ }^{[252,253,254]}$ The dendrite arm spacing and secondary arm spacing determine the microforces acting on inclusions, and the fluid flow condition, thus affect inclusion entrapment. Figure 41 shows that the secondary dendrite arm spacing increases with time (cooling rate) and distance from the surface of an electric slag remelting ingot. ${ }^{[248]}$ The figure also indicates that the secondary arm space is 200 to $500 \mu \mathrm{m}$, in the order of the diameter of exogenous inclusions. The cooling rate determines the second arm spacing, and thus should have a significant effect on inclusion entrapment.

Two studies ${ }^{[8,255]}$ of top-poured ingots found that larger slag inclusions concentrate in the central bottom portion of the ingot and in the outer portions of the ingot top, as shown in Figure 42. ${ }^{[8]}$ In bottom-poured ingots, the large inclusions were more uniformly distributed and fewer in number. ${ }^{[8]}$ The effect of teeming temperature on the distribution of large alumina inclusion clusters (larger than $50 \mu \mathrm{m})$ in an ingot is shown in Figure 43. ${ }^{[122]}$ This figure indicates that increased teeming temperature decreases the amount of inclusions, because it facilitates their floatation removal by natural convection. Natural convection due to cooling the steel near the mold walls causes a downward flow along the walls and an upward flow in the middle of the ingot. The slow solidification gives inclusions more time to collide, and the upward flow in the middle of the ingot promotes the separation of the inclusions to the top part of the ingot where they can be assimilated into the mold flux. In ingot A poured at a low temperature, the inclusions are trapped in the surface layer of the sides near the top of the ingot and in the central core at the bottom. In ingot $\mathrm{B}$, the higher pouring temperature allowed more inclusions to escape to the top surface slag layer ${ }^{[122]}$ For a bottom-poured $2 \mathrm{t}$ ingot (with taper) of $0.50 \mathrm{pct} \mathrm{C}, \mathrm{Al}-\mathrm{Si}$ killed steel, the high-melting-point inclusions (high alumina) predominate at the bottom of the ingot, while low-melting-point inclusions (sulfide and silicates) are more abundant in its top central portion, due to the mechanism of positive segregation. ${ }^{[175]}$ The shape and position of the bottom cone of negative segregation coincides with the bottom cone of inclusions in $2.2 \mathrm{t}$ bottom-poured ingots. This is attributed to these inclusions being entrapped in the dendrites of relatively pure equiaxed grains and dropping to the bottom together as a shower ${ }^{[152]}$ This hypothesis is supported by many researchers. ${ }^{[245,256-259]}$

Inclusion content is also related to yield in ingot casting. Exothermic "hot" top or an insulating powder in the ingot mold helps to extend the liquid stage near the mold top. This allows more inclusions to float into the top region before final solidification. In order to have a good quality final product, an optimal portion of the top part of the ingot, including the rough surface caused by the hot-top boards, must be cut off. Sometimes, part of the bottom is cut off as well. This removes the most inclusion-rich regions from the finished product at the expense of lower yield. 


\section{SUMMARY AND RECOMMENDATIONS}

This article extensively reviews published research on inclusions in ingot steel and defects on ingot products; methods to measure and detect inclusions in steel; the causes of exogenous inclusions; and the transport and

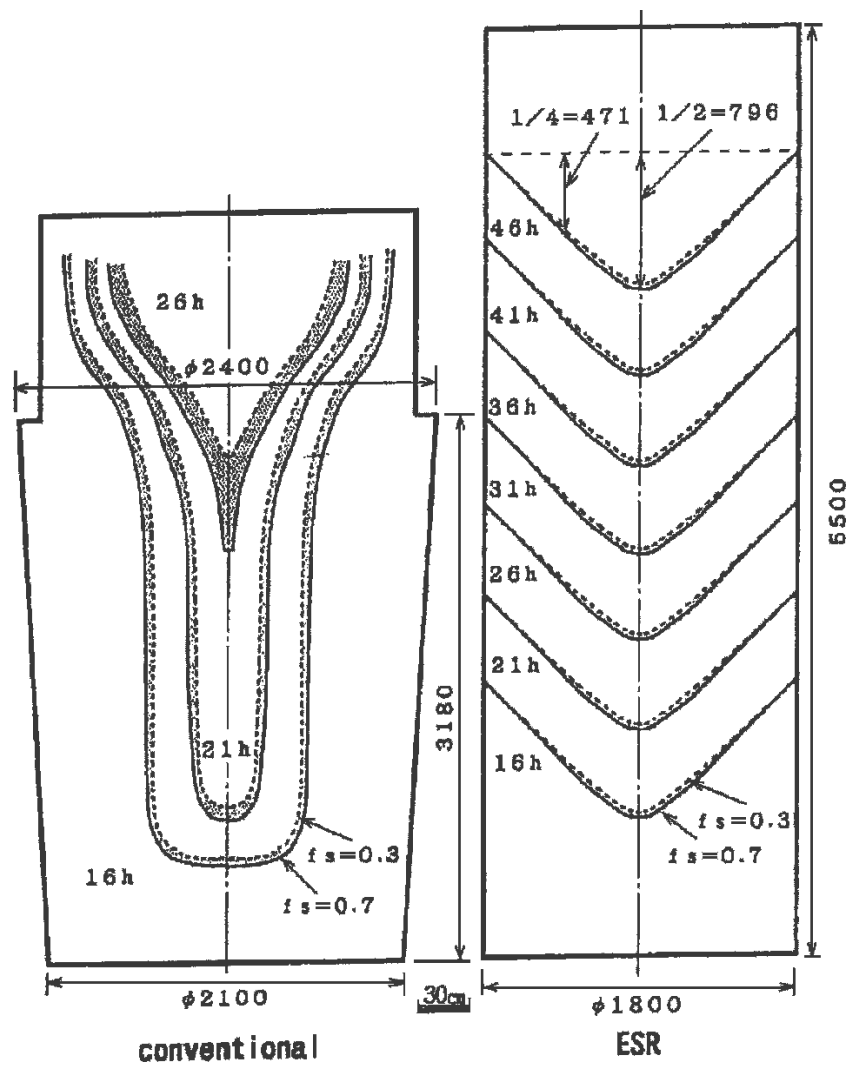

Fig. 40-Comparison of the solidification pattern of a conventional melting furnace and ESR. ${ }^{[248]}$

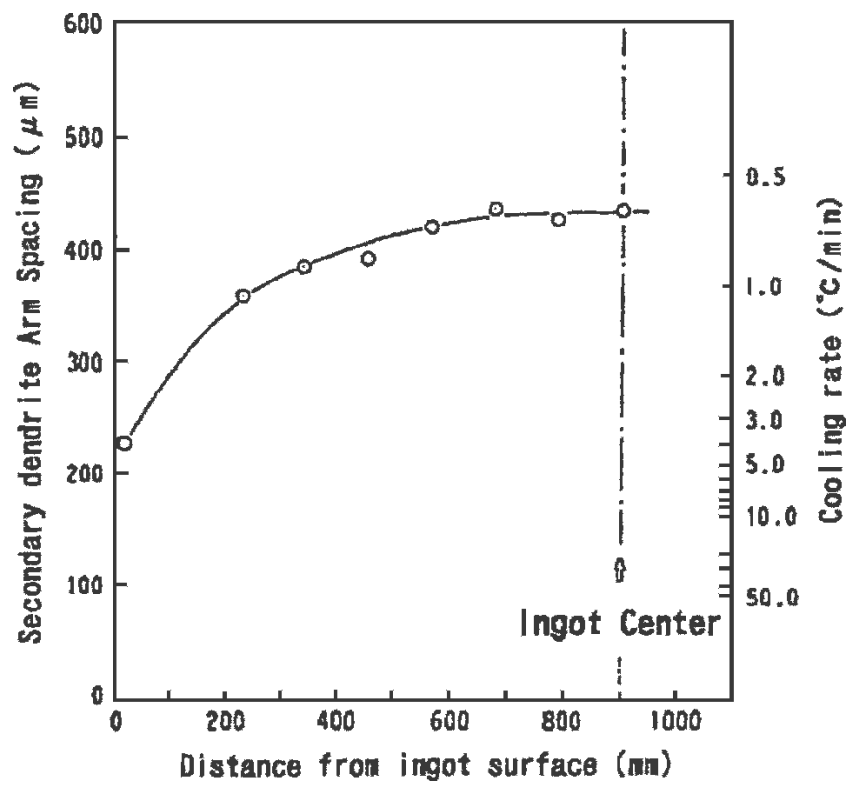

Fig. 41-Secondary dendrite arm spacing measured in 1800-mm outer diameter ESR ingot. ${ }^{[248]}$ entrapment of inclusions during fluid flow, segregation, and solidification of steel cast in ingot molds. Exogenous inclusions in ingots originate mainly from reoxidation of the molten steel, slag entrapment, and lining erosion. The following methods can be used to minimize inclusions from entering the ingot mold and becoming entrapped during bottom-poured ingot casting:

1. minimize refractory erosion by optimizing steelmaking and steel refining;

2. fully deoxidize the steel (to lower dissolved oxygen levels) and avoid high-Mn steels;

3. minimize reoxidation materials $(\mathrm{MnO}$ and $\mathrm{FeO})$ from slag carryover;

4. use pure refractories with minimal silica;

5. design runners to minimize flow impact and velocity across on sensitive refractories;

6. avoid air reoxidation, especially during transfer operations, by using optimized flow conditions and effective sealing systems that include inert-gas shrouding;

7. optimize ingot geometry and negative taper to encourage inclusion floating and lessen turbulence and entrapment;

8. increase superheat entering the mold and optimize filling rates to avoid spouting;

9. use ceramic foam filters at the runner system near the ingate;

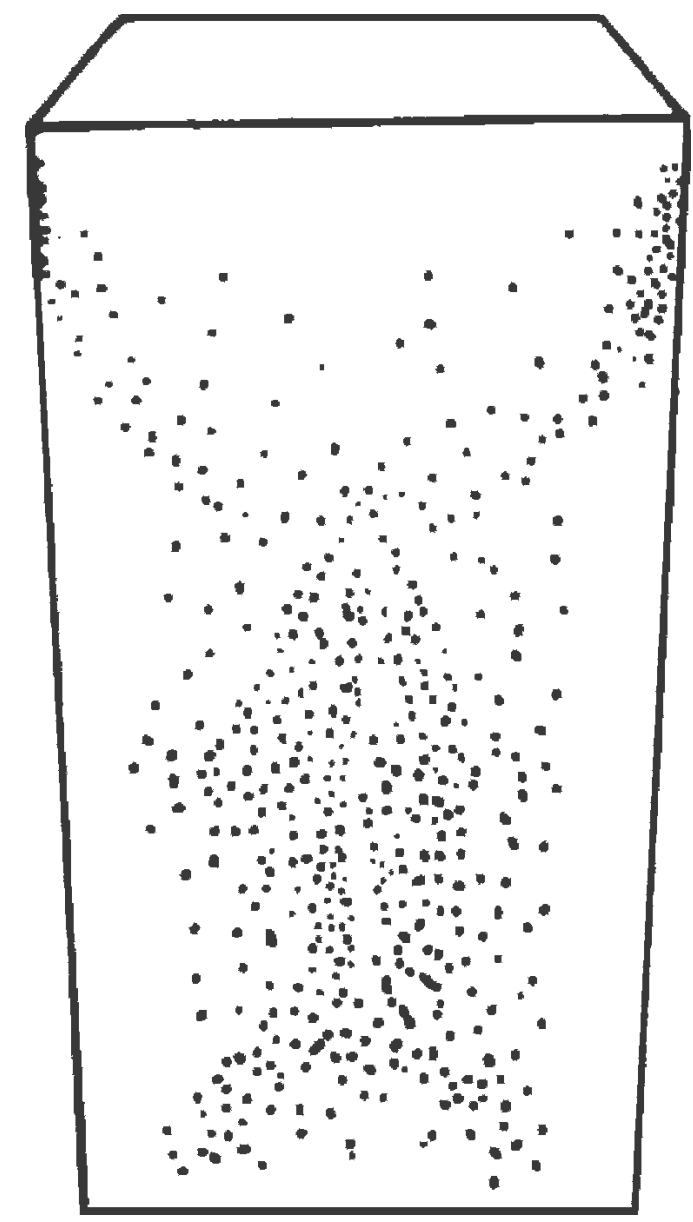

Fig. 42-Distribution of large slag inclusions in a top-poured 5-t ingot. ${ }^{[8]}$ 


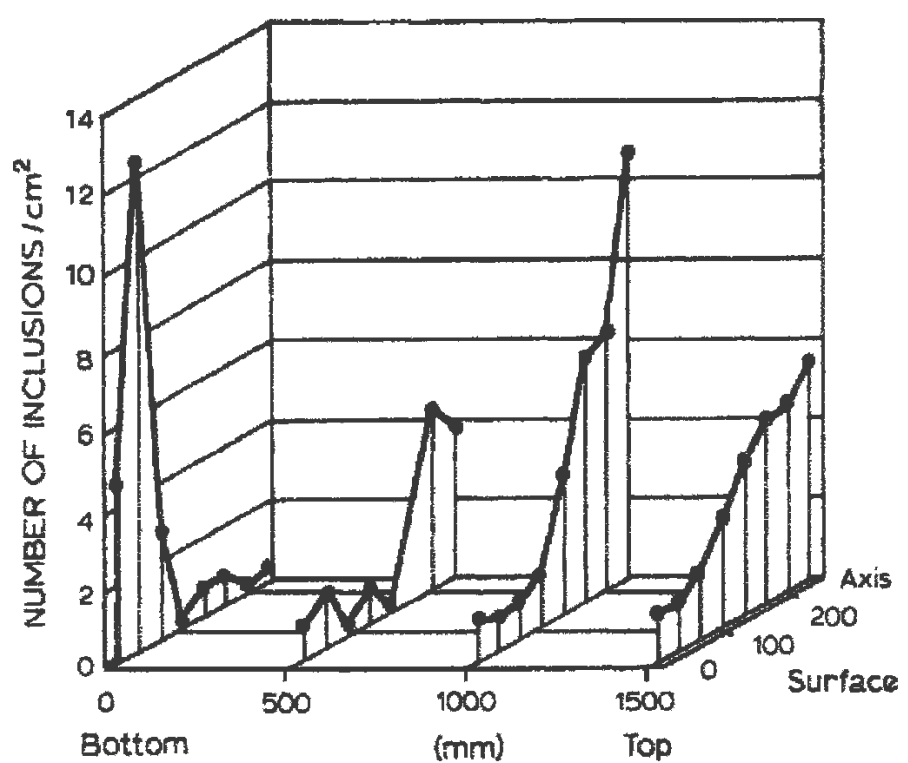

(a)

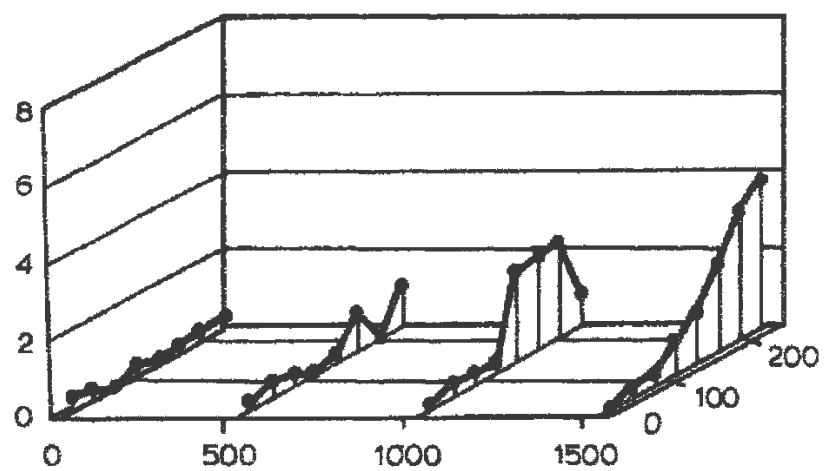

(b)

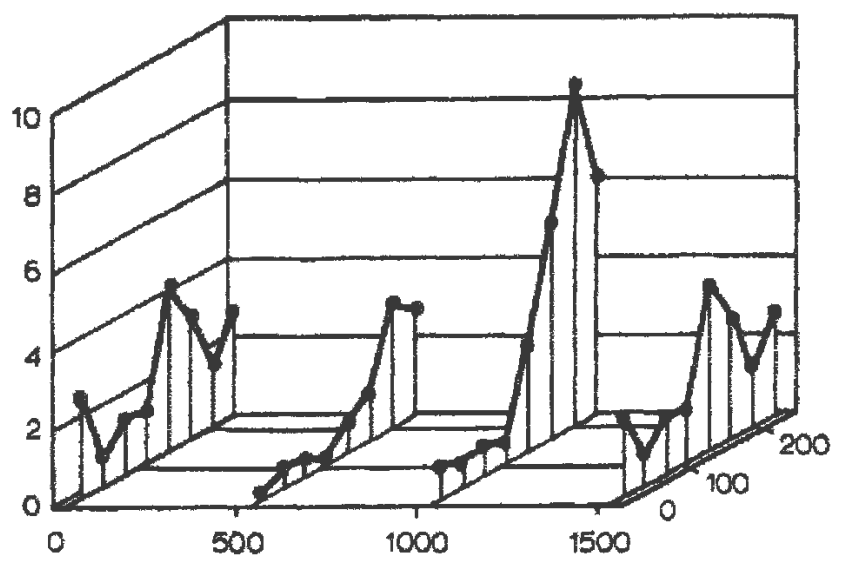

(c)

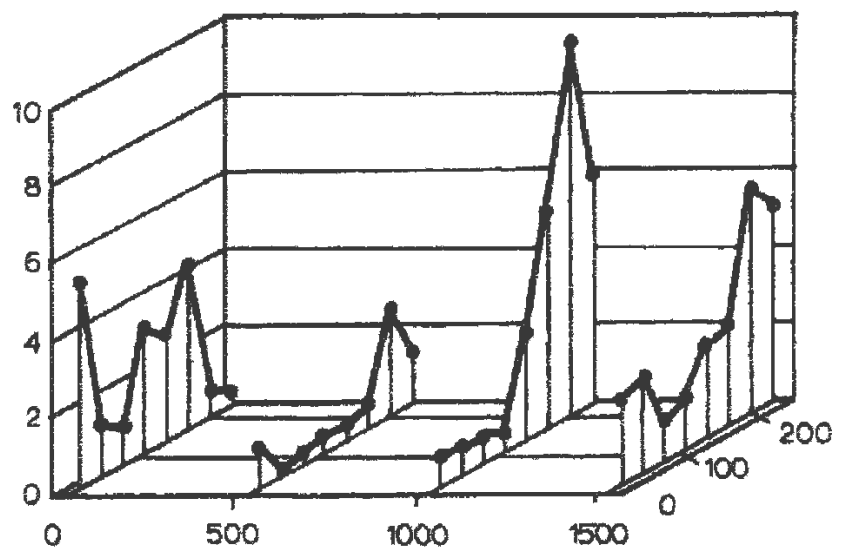

(d)

(a) charging into the furnace, theming tomperature $1528^{\circ} \mathrm{C}$; (b) charging into the furnace, toeming temperature $1550^{\circ} \mathrm{C}$ : (c) charging into the furnace, toeming temperature $1538^{\circ} \mathrm{C}$; (d) charging into the fumace, teeming temperature $1547^{\circ} \mathrm{C}$

Fig. 43- (a) through $(d)$ Distribution of large inclusions in bottom-poured ingots at different teeming temperatures. ${ }^{[122]}$

10. use board top compounds to prolong surface solidification time and lessen slag entrainment (when using powder bags, suspend them near the bottom, but just above the "spout" height); and

11. reheat ingots using temperature-time cycles that avoid precipitation of inclusions.

Based on the knowledge gained from this review, the following four new methods are proposed for further investigation to improve steel cleanliness for bottom-poured ingot casting.

1. Optimize the runner shape to absorb inclusions before they enter the mold. Inclusions tend to move upward so they might be trapped by weirs or inclusion-entrapment cavities near the end of runners.

2. Optimize ingate geometry design. Extend the ingate length to obtain a uniform vertical inflow into the mold, and control the velocity to decrease the top surface level fluctuations, turbulence, slag entrapment, and reoxidation during filling. ${ }^{[3]}$

3. Optimize the teeming rate for a given ingate design to avoid "spouting" and turbulence. It is recommended that during the first several minutes, the teeming rate is kept at this low critical value, and then after there is some height of molten steel in the mold, the teeming rate can be increased gradually.

4. Optimize the suspended height of powder bags close to the ingot bottom, or prevent spouting by adding a thin steel plate near the bottom of the mold, with powder on top.

\section{REFERENCES}

1. Steel Statistical Yearbook 2002, International Iron and Steel Institute, Brussels, 2002, pp. 13-16.

2. E. Fuchs and P. Jonsson: High Temp. Mater. Proc., 2000, vol. 19 (5), pp. 333-43. 
3. K. Sumitomo, M. Hashio, T. Kishida, and A. Kawami: Iron Steel Engineer, 1985, vol. 62 (3), pp. 54-61.

4. Schematic Illustration of Ingot Bottom Pouring Process, www.foseco-steel.com/pics/pic_products_ic_ov.gif.

5. T. Sjokvist, M. Goransson, P. Jonsson, and P. Cowx: Ironmaking and Steelmaking, 2003, vol. 30 (1), pp. 73-80.

6. P.K. Trojan: ASM Handbook, vol. 15, Casting, ASM INTERNATIONAL, Metals Park, OH, 1988, pp. 88-97.

7. T.J. Baker and J.A. Charles: in Effect of Second-Phase Particles on the Mechanical Properties of Steel, M.J. May, ed., The Iron and Steel Institute, Scarborough, United Kingdom, 1971, pp. 88-94.

8. S.E. Lunner: Int. Conf. on Production and Application of Clean Steels, The Iron and Steel Institute, London, 1970, pp. 124-36.

9. A.D. Wilson: in Advances in the Production and Use of Steel with Improved Internal Cleanliness, J.K. Mahaney, ed., ASTM, Philadelphia, PA, 1999, pp. 73-88.

10. R. Kiessling: Met. Sci., 1980, vol. 15 (5), pp. 161-72.

11. L. Zhang and B.G. Thomas: Iron Steel Inst. Jpn. Int.., 2003, vol. 43 (3), pp. 271-91.

12. J.A. Eckel, P.C. Glaws, J.O. Wolfe, and B.J. Zorc: in Advances in the Production and Use of Steel with Improved Internal Cleanliness, J.K. Mahaney, ed., ASTM, Philadelphia, PA, 1999, pp. $1-11$.

13. T.B. Lund and L.K.P. Olund: in Advances in the Production and Use of Steel with Improved Internal Cleanliness, J.K. Mahaney, ed., ASTM, Philadelphia, PA, 1999, pp. 32-48.

14. T. Uesugi: Tetsu-to-Hagané, 1988, vol. 74, pp. 1889-94.

15. D.C. Hilty and D.A.R. Kay: Electric Furnace Steelmaking Conf. Proc., ISS, Warrendale, PA, 1985, vol. 43, pp. 237-51.

16. R.A. Rege, E.S. Szekeres, and W.D. Forgeng: Metall. Trans. AIME, 1970, vol. 1 (9), p. 2652.

17. R. Rastogi and A.W. Cramb: 2001 Steelmaking Conf. Proc., ISS, Warrendale, PA, 2001, vol. 84, pp. 789-829.

18. R. Dekkers, B. Blanpain, and P. Wollants: ISSTech2003 Conf. Proc., ISS, Warrendale, PA, 2003, pp. 197-209.

19. H. Ooi, T. Sekine, and G. Kasai: On the Mechanisms of Alumina Cluster Formation in Molten Iron, 1975, Trans. ISIJ, vol. 15, pp. 371-79.

20. C. Wagner: Z. Elektrochemie, 1961, vol. 65, pp. 581-91.

21. W. Ostwald: Z. Phys. Chem., 1900, vol. 34, p. 495.

22. M. Kahlweit: Ber. Bunsenges. Phys. Chem., 1974, vol. 78 (10), pp. 997-1001.

23. L. Ratke and W.K. Thieringer: Acta Metall., 1985, vol. 33 (10), pp. 1793-802, 1032.

24. I.M. Lifshitz and V.V. Slyozov: J. Phys. Chem. Solids, 1961, vol. 19 (1-2), pp. 35-50.

25. L. Zhang and B.G. Thomas: 7th Eur. Electric Steelmaking Conf., Venice, Italy, Associazione Italiana di Metallurgia, Milano, Italy, 2002, vol. II, pp. 2.77-2.86.

26. L. Zhang, W. Pluschkell, and B.G. Thomas: ' 85 Steelmaking Conf. Proc., ISS, Warrendale, PA, 2002, vol. 85, pp. 463-76.

27. R. Dekkers, B. Blanpain, and P. Wollants: Metall. Mater. Trans. B, 2003, vol. 34B, pp. 161-71.

28. F.B. Pickering: Int. Conf. on Production and Application of Clean Steels, The Iron and Steel Institute, London, 1970, pp. 75-91.

29. Z. Majewski: Int. Conf. on Production and Application of Clean Steels, The Iron and Steel Institute, London, 1970, pp. 68-74.

30. Y. Miki, H. Kitaoka, T. Sakuraya, and T. Fujii: Tetsu-to-Hagané, 1992, vol. 78 (3), pp. 431-38.

31. J.P. Bettembourg, J. Dieudonne, J.J. Gautier, and F. Sauvage: Int. Conf. on Production and Application of Clean Steels, The Iron and Steel Institute, London, 1970, pp. 59-67.

32. E. Grethen and L. Philipe: Int. Conf. on Production and Application of Clean Steels, The Iron and Steel Institute, London, 1970, pp. 2934.

33. J.A. Horwath and G.M. Goodrich: AFS Trans., 1995, vol. 103, pp. 495-510.

34. V.A. Kravchenko, V.M. Kirsanov, M.I. Staroseletskij, N.G. Miroshnichenko, A.G. Petrichenko, I.G. Uzlov, and L.A. Moiseeva: Metallurgicheskaya i Gornorudnaya Promyshlennost', 2000, vol. 1 (1), pp. 26-30 (in Russian).

35. K. Beskow, J. Jia, C.H.P. Lupis, and D. Sichen: Ironmaking and Steelmaking, 2002, vol. 29 (6), pp. 427-35.

36. X. Zhang and M. Subramanian: 85th Steelmaking Conf. Proc., ISS, Warrendale, PA, 2002, vol. 85, pp. 313-22.
37. K.R. Udupa, S. Subramanian, D.H. Sastry, and G.N.K. Lyengar: Mater. Forum, 1993, vol. 17, pp. 225-34.

38. T. Kawawa and M. Ohkubo: A Kinetics on Deoxidation of Steel, 1968, Trans. ISIJ, vol. 8, pp. 203-19.

39. K. Asano and T. Nakano: Deoxidation of Molten Steel with Deoxidizer, 1972, Trans. ISIJ, vol. 12, pp. 343-49, 1010.

40. E.T. Turkdogan: Deoxidation of Steel, JISI, 1972, vol. 210(1), pp. 21-36.

41. T. Fujisawa: Nishiyama Memorial Seminar, ISIJ, Tokyo, 1988, vols. 126-127, pp. 89-120.

42. K. Beskow, N.N. Viswanathan, L. Jonsson, and D. Sichen: Metall. Mater. Trans. B, 2001, vol. 32B, pp. 319-28.

43. D. Fan and G. Liu: Steelmaking, 2000, vol. 16 (1), pp. 43-46 (in Chinese).

44. H. Hosoda, N. Sano, and Y. Matsushita: Growth and Change of Deoxidation Products in Deoxidation with Silicon and SiliconManganese in Liquid Iron, 1976, Trans. ISIJ, vol. 16, pp. 115-21.

45. K. Nakanishi and J. Szekely: Deoxidation Kinetics in a Turbulent Flow Field, 1975, Trans. ISIJ, vol. 15, pp. 522-30.

46. M. Olette and C. Gatellier: Information Symp. of Casting and Solidification of Steel, J.M. Gibb, ed., IPC Science and Technology Press Ltd., Guildford, 1977, vol. 1, pp. 1-60.

47. I.N. Golikov: Int. Conf. on Production and Application of Clean Steels, The Iron and Steel Institute, London, 1970, pp. 35-41.

48. N. Aritomi and K. Gunji: Trans. Jpn. Met., 1981, vol. 22 (1), pp. 43-56.

49. T. Sawai, M. Wakoh, Y. Ueshima, and S. Mizoguchi: Iron Steel Inst. Jpn. Int., 1992, vol. 32 (1), pp. 169-73.

50. H. Goto, K.-I. Miyazawa, K.-I. Yamaguchi, S. Ogibayashi, and K. Tanaka: Iron Steel Inst. Jpn. Int., 1994, vol. 34 (5), pp. 414-19.

51. Z. Ma and D. Janke: Iron Steel Inst. Jpn. Int., 1998, vol. 38 (1), pp. 46-52.

52. Y.N. Malinochka, L.N. Nagnyuk, and Y.S. Shmelev: Steel USSR, 1990, vol. 20 (3), pp. 136-38.

53. R. Dekkers, B. Blanpain, and P. Wollants: in ISSTech2003 Conf. Proc., ISS, Warrendale, PA, 2003, pp. 1007-19.

54. L. Zhang and W. Pluschkell: Ironmaking and Steelmaking, 2003, vol. 30 (2), pp. 106-10.

55. Y. Miyashita and K. Nishikawa: Measurement of Size Distribution of Nonmetallic Inclusions in Steel, 1968, Trans. ISIJ, vol. 8, pp. 181-85.

56. S. Linder: Scand. J. Metall., 1974, vol. 3, pp. 137-50.

57. E.T. Turkdogan: J. Iron Steel Inst., 1966, pp. 914-19.

58. M. Suzuki, M. Suzuki, and M. Nakada: Iron Steel Inst. Jpn., 2001, vol. 41 (7), pp. 670-82.

59. B.G. Thomas, Q. Yuan, L. Zhang, and S.P. Vanka: 2002 NSF Design, Service, Manufacturing and Industrial Innovation Research Conf. Proc., National Science Foundation, Washington, DC, 2002.

60. G.V. Pervushin and H. Suito: Iron Steel Inst. Jpn. Int., 2001, vol. 41 (7), pp. 748-56.

61. K. Wasai and K. Mukai: Metall. Mater. Trans. B, 1999, vol. 30B, pp. 1065-74.

62. S. Kobayashi: Iron Steel Inst. Jpn. Int., 1999, vol. 39 (7), pp. 664-70.

63. U. Lindborg and K. Torssell: Trans. ASME, 1968, vol. 242, pp. 94102.

64. K. Nogi: Tetsu-to-Hagané, 1998, vol. 84 (1), pp. 1-6.

65. K. Okohira, N. Sato, and H. Mori: Observation of Three-Dimensional Shapes of Inclusions in Low-Carbon Aluminum-Killed Steel by Scanning Electron Microscope, Trans. ISIJ, 1974, vol. 14, pp. $103-$ 09.

66. M. Olette: Institut de Recherches de La Siderurgie Francaise Report, IRSIO, Paris, France, 1972.

67. N. Aritomi and K. Gunji: Morphology and Formation Mechanism of Dendritic Inclusions in Iron and Iron-Nickel Alloys Deoxidized with Silicon and Solidified Unidirectionally, Trans. ISIJ, 1979, vol. 19, pp. 152-61.

68. T.B. Braun, J.F. Elliott, and M.C. Flemings: Metall. Trans. B, 1979, vol. $10 \mathrm{~B}$, pp. 171-84.

69. N. Aritomi and K. Gunji: On the Formation of Dendritic Inclusion from a Spherical Primary Silica in Iron-10 Pct Nickel Alloy Deoxidized with Silicon, Trans. ISIJ, 1980, vol. 20, pp. 26-32.

70. Y. Miki, H. Kitaoka, T. Sakuraya, and T. Fujii: Iron Steel Inst. Jpn. Int., 1992, vol. 32 (1), pp. 142-49.

71. T. Murai, H. Matsuno, E. Sakurai, and H. Kawashima: Tetsuto-Hagané, 1998, vol. 84 (1), pp. 13-18. 
72. F.G. Wilson and T. Gladman: Int. Mater. Rev., 1988, vol. 33 (5), pp. 221-86.

73. S. Yang: Iron Steel (China), 1987, vol. 22 (11), pp. 11-16.

74. L. Zhang, B. Rietow, K. Eakin, and B.G. Thomas: Iron Steel Inst. Jpn. Int., 2006, vol. 46 (5), pp. 670-79.

75. G. Auclair, M. Falcoz-Vigne, F. Lecouturier, and J. Saleil: Wire J. Int., 1998, vol. 31 (3), pp. 84-89.

76. G. Pomey and B. Trentini: Int. Conf. on Production and Application of Clean Steels, The Iron and Steel Institute, London, 1970, pp. 1-14.

77. A.G. Franklin: Int. Conf. Production and Application of Clean Steels, The Iron and Steel Institute, London, 1970, pp. 241-47.

78. R. Jack: Met. Forum, 1979, vol. 2 (2), pp. 87-97.

79. R. Rastogi and A.W. Cramb: Carnegie Mellon University, Pittsburgh, PA, private communication, 2003.

80. "Surface Defects in Ingots and Their Products," Special Report No. 63, Ingot Surface Defects Sub-Committee (Steelmaking Division), British Iron and Steel Research Association, London, 1958.

81. Definitions and Causes of Continuous Casting Defects, The Iron and Steel Institute, London, 1967

82. V.B. Ginzburg and R. Ballas: Flat Rolling Fundamentals, Marcel Dekker, Inc., New York, NY, 2000, pp. 354-78.

83. M. Byrne, T.W. Fenicle, and A.W. Cramb: Steelmaking Conf. Proc., ISS, Warrendale, PA, 1985, vol. 68, pp. 451-61.

84. M. Byrne, T.W. Fenicle, and A.W. Cramb: Iron Steelmaker, 1988 , vol. 15 (6), pp. 41-50.

85. M. Byrne, T.W. Fenicle, and A.W. Cramb: ISS Trans., 1989, vol. 10, pp. 51-60.

86. H. Yin and H.T. Tsai: ISSTech2003 Conf. Proc., ISS, Warrendale, PA, 2003, pp. 217-26.

87. R. Gass, H. Knoepke, J. Moscoe, R. Shah, J. Beck, J. Dzierzawski, and P.E. Ponikvar: ISSTech2003 Conf. Proc., ISS, Warrendale, PA, 2003, pp. 3-18.

88. J.C.C. Leach: Int. Conf. on Production and Application of Clean Steels, The Iron and Steel Institute, London, 1970, pp. 105-14.

89. M. Byrne and A.W. Cramb: Iron Steelmaker, 1988, vol. 15 (10), pp. 45-53.

90. P. Rocabois, J.-N. Pontoire, V. Delville, and I. Marolleau: ISSTech2003 Conf. Proc., ISS, Warrendale, PA, 2003, pp. 995-1006.

91. Y.N. Malinochka, P.L. Litvinenko, V.S. Luchkin, and V.A. Maslennikov: Steel Translation, 1992, vol. 22 (3), pp. 144-47.

92. Y. Miki and S. Takeuchi: Iron Steel Inst. Jpn., 2003, vol. 43 (10), pp. $1548-55,1018$

93. L. Zhang, B.G. Thomas, and B. Rietow: IMF Project Report No. CCC200406, University of Illinois at Urbana-Champaign, Urbana, IL, 2004.

94. L. Zhang and S. Taniguchi: Iron Steelmaker, 2001, vol. 28 (9), pp. 55-79.

95. L. Zhang and S. Taniguchi: Int. Mater. Rev., 2000, vol. 45 (2), pp. 59-82.

96. L. Zhang and S. Taniguchi: Ironmaking and Steelmaking, 2002, vol. 29 (5), pp. 326-36

97. S. Dawson, N.D.G. Mountford, I.D. Sommerville, and A. McLean: Iron Steelmaker, 1988, vol. 15 (7), pp. 42-43.

98. S. Dawson, N.D.G. Mountford, I.D. Sommerville, and A. McLean: Iron Steelmaker, 1988, vol. 15 (8), pp. 34-36.

99. S. Dawson, N.D.G. Mountford, I.D. Sommerville, and A. McLean: Iron Steelmaker, 1988, vol. 15 (9), pp. 56-57.

100. S. Dawson, N.D.G. Mountford, I.D. Sommerville, and A. McLean: Iron Steelmaker, 1988, vol. 15 (10), pp. 54-55.

101. S. Dawson, N.D.G. Mountford, I.D. Sommerville, and A. McLean: Iron Steelmaker, 1988, vol. 15 (11), pp. 63-64.

102. S. Dawson, N.D.G. Mountford, I.D. Sommerville, and A. McLean: Iron Steelmaker, 1988, vol. 15 (12), pp. 26-28.

103. S. Dawson, N.D.G. Mountford, I.D. Sommerville, and A. McLean: Iron Steelmaker, 1989, vol. 16 (1), pp. 44-45

104. S. Dawson, N.D.G. Mountford, I.D. Sommerville, and A. McLean: Iron Steelmaker, 1989, vol. 16 (2), pp. 36-37.

105. T.R. Allmand: J. Iron Steel Inst., 1958, vol. 190, pp. 359-72.

106. H. Suito, J. Takahashi, and A. Karasev: 11th Ultra-Clean Steel Symp. of High Temperature Process Committee of ISIJ, ISIJ, Tokyo, 1998, pp. 1-20.

107. J. Angeli, H. Flobholzer, K. Jandl, T. Kaltenbrunner, W. Posch, and H. Preblinger: La Rev. Metall.-CIT, 1999, vol. 96 (4), pp. 521-27.

108. L. Zhang and K. Cai: "Project Report: Cleanliness Investigation of Low Carbon Al-Killed Steel in Bao Steel," BaoSteel, Shanghai, China, 1997.
109. T. Hansen and P. Jonsson: 2001 Electric Furnace Conf. Proc., ISS, Warrendale, PA, 2001, vol. 59, pp. 71-81.

110. H. Matsuta, T. Sato, and M. Oku: Iron Steel Inst. Jpn. Int., 1996, vol. 36 (Suppl.), pp. S125-127.

111. M. Goransson, F. Reinholdsson, and K. Willman: Iron Steelmaker, 1999, vol. 26 (5), pp. 53-58.

112. F. Ruby-Meyer and G. Willay: Rev. Metall.-CIT, 1997, vol. 94 (3), pp. 367-78.

113. R. Meilland, H. Hocquaux, C. Louis, L. Pollino, and F. Hoffert: La Rev. Metall.-CIT, 1999, vol. 96 (1), pp. 88-97.

114. M. Burty, C. Louis, P. Dunand, P. Osmont, F. Ruby-Meyer, M. Nadif, F. Penet, T. Isono, E. Takeuchi, and T. Toh: La Rev. Metall.-CIT, 2000, vol. 97 (6), pp. 775-82.

115. T. Saitoh, T. Kikuchi, and K. Furuya: Iron Steel Inst. Jpn., 1996, vol. 36, Suppl., pp. S121-124.

116. N.K. Batia and H.H. Chaskelis: NDT E. Int., 1975, vol. 8, pp. 261-64.

117. P. Bastien: NDT E. Int., 1977, vol. 10, pp. 297-305.

118. B. Debiesme, I. Poissonnet, P. Choquet, and F. Penet: Rev. Metall. CIT, 1993, vol. 90 (3), pp. 387-94.

119. R. Eriksson: Thesis, Royal University of Technology, Stockholm, Sweden, 2001.

120. P.C. Glaws, R.V. Fryan, and D.M. Keener: 74th Steelmaking Conf. Proc., ISS, Warrendale, PA, 1991, vol. 74, p. 247-64.

121. W. Betteridge and R.S. Sharpe: J. Iron Steel Inst., 1948, vol. 158, pp. $185-91$

122. M. Ichinoe, H. Mori, H. Kajioka, and I. Kokubo: Int. Conf. on Production and Application of Clean Steels, The Iron and Steel Institute, London, 1970, pp. 137-66.

123. S.D. Strauss: Power, 1983, June, pp. s1-16.

124. R.C. Sussman, M. Burns, X. Huang, and B.G. Thomas: 10th Process Technology Conf. Proc., ISS, Warrendale, PA, 1992, vol. 10, pp. 291304

125. T.E. Rooney and A.G. Stapleton: J. Iron Steel Inst., 1935, vol. 31, pp. 249-54.

126. Y. Yoshida and Y. Funahashi: Trans. Iron Steel Inst. Jpn., 1976, vol. 16 (11), pp. 628-36.

127. Y. Nuri and K. Umezawa: Tetsu-to-Hagané, 1989, vol. 75 (10), pp. 1897-904.

128. Y. Murakami: J. Res. Nat. Inst. Standards Technol., 1994, vol. 99 (4), pp. 345-51.

129. H. Kuguminato, Y. Izumiyama, T. Ono, T. Shiraishi, and H. Abe: Kawasaki Steel Technol. Rep., 1980, vol. 12 (2), pp. 331-38.

130. G.R. Webster, J.M. Madritch, G.A. Perfetti, and L.C. Wong: Iron Steelmaker, 1985, vol. 12 (10), pp. 18-27.

131. A.S. Venkatadri: Mechanism of Formation of Non-Metallic Inclusions in Aluminum-Killed Steel, Trans. ISIJ, 1978, vol. 18, pp. 591600 .

132. A. Chino, Y. Kawai, H. Kutsumi, and M. Kawakami: Iron Steel Inst Jpn. Int., 1996, vol. 36 (Suppl.), pp. S144-147.

133. T.L. Mansfield: Mater. Evaluation, 1983, vol. 41 (6), pp. 743-47.

134. S. Dawson, D. Walker, N. Mountford, I.D. Sommerville, and A. McLean: Can. Inst. Mining Metall., 1988, pp. 80-91.

135. R.I.L. Guthrie and H.C. Lee: Steelmaking Conf. Proc., Toronto, ISS, Warrendale, PA, 1992, vol. 75, pp. 799-805.

136. R.I.L. Guthrie: in Foundry Process-Their Chemistry and Physics, S. Katz and C.F. Landefeld, eds., Plenum Press, New York, NY, 1988, pp. $447-66$

137. H. Yin, H. Shibata, T. Emi, and M. Suzuki: Iron Steel Inst. Jpn. Int., 1997, vol. 37 (10), pp. 936-45

138. H. Yin, H. Shibata, T. Emi, and M. Suzuki: Iron Steel Inst. Jpn. Int., 1997, vol. 37 (10), pp. 946-55

139. H. Shibata, H. Yin, S. Yoshinaga, T. Emi, and M. Suzuki: Iron Steel Inst. Jpn. Int., 1998, vol. 38 (2), pp. 149-56.

140. S. Makarov, R. Ludwig, and D. Apelian: Meas. Sci. Technol., 1999, vol. 10 (11), pp. 1047-53.

141. J. Schade: Steel Technology International, 1993, p. 149

142. M.T. Burns, J. Schade, and C. Newkirk: 74th Steelmaking Conf. Proc., ISS, Warrendale, PA, 1991, vol. 74, pp. 513-23.

143. C. Bonilla: 78th Steelmaking Conf. Proc., ISS, Warrendale, PA, 1995, vol. 78 , pp. 743-52.

144. K. Ito: 165th-166th Nishiyama Memorial Seminar, ISIJ, Tokyo, 1997, pp. 1-24.

145. M. Olette and C. Catellier: 2nd Int. Conf. on Clean Steel, Balatonfured, Hungary, The Metals Society, London, 1983, pp. $165-85$ 
146. S. Armstrong: 76th Steelmaking Conf. Proc., ISS, Warrendale, PA, 1993, vol. 76, pp. 475-81.

147. S.D. Melville and L. Brinkmeyer: 78th Steelmaking Conf. Proc., ISS, Warrendale, PA, 1995, pp. 563-69.

148. R.L. Shultz: Steelmaking Conf. Proc., 1979, vol. 62, pp. 232-35.

149. A. Yamanaka and H. Ichiashi: Iron Steel Inst. Jpn. Int., 1992, vol. 32 (5), pp. 600-06.

150. R. Tsujino, A. Tanaka, A. Imamura, D. Takahashi, and S. Mizoguchi: Tetsu-to-Hagané, 1994, vol. 80 (10), pp. 31-36.

151. G. Hassall, K. Bain, N. Jones, and M. Warman: Ironmaking and Steelmaking, 2002, vol. 29 (5), pp. 383-89.

152. M.D. Maheshwari, T. Mukherjee, and J.J. Irani: Ironmaking and Steelmaking, 1982, vol. 9 (4), pp. 168-77.

153. S. Riaz, K.C. Mills, and K. Bain: Ironmaking and Steelmaking, 2002, vol. 29 (2), pp. 107-13.

154. J.M. Middleton and B. Cauwood: Br. Foundryman, 1967, vol. 60 (8), pp. 320-30, 998

155. G. Benko, S. Simon, and G. Szarka: Neue Hutte, 1972, vol. 17 (1), pp. $40-44$

156. H. Zeder and L. Pocze: Berg Huttenmann. Monatsh., 1980, vol. 125 (1), pp. 1-5

157. T. Komai: Tetsu-to-Hagané, 1981, vol. 67 (8), pp. 1152-61.

158. M. Burty, P. Dunand, J. Ritt, H. Soulard, A. Blanchard, G. Jeanne, F. Penet, R. Pluquet, and I. Poissonnet: Ironmaking Conf. Proc., 1997, vol. 56, pp. 711-17.

159. L. Zhang and K. Cai: Project Report: Cleanliness Investigation of Low Carbon Al-Killed Steel Produced by LD-RH-CC Process at WISCO, WISCO, Wuhan, China, 1995.

160. X. Zhang and K. Cai: Project Report: Investigation of Inclusion Behavior of 16MnR Steel at WISCO,WISCO, Wuhan, China, 1996.

161. Y. Furuya, S. Matsuoka, and T. Abe: Tetsu-to-Hagané, 2002, vol. 88 (10), pp. 643-50

162. J.D. Thomas, R.O. Russell, and T.R. Garcia: 69th Steelmaking Conf. Proc., ISS, Warrendale, PA, 1986, pp. 300-08.

163. A.W. Cramb: Inclusion Formation during Foundry Processing, http:// neon.mems.cmu.edu/afs/afs2/window2.html, 1996.

164. M. Blair, R.W. Monroe, and J.A. Griffin: in Advances in the Production and Use of Steel with Improved Internal Cleanliness, J.K. Mahaney, ed., ASTM, Philadelphia, PA, 1999, pp. 57-72.

165. R. Topno, D.S. Gupta, U.P. Singh, B. Roy, and S. Jha: Scand. J. Metall., 2002, vol. 31 (1), pp. 20-24.

166. J.M. Svoboda, R.W. Monroe, C.E. Bates, and J. Griffin: AFS Trans., 1987, vol. 95. pp. 187-202.

167. R. Schlatter: Steel Times, 1986, No. 8, pp. 432-36.

168. T.J. Ward, R.F. Schmehl, and F.A. Vonesh: 67th Steelmaking Conf. Proc, ISS, Warrendale, PA, 1984, vol. 67, pp. 97-102.

169. T.W. Scamman and S.J. Miller: 67th Steelmaking Conf. Proc, ISS, Warrendale, PA, 1984, vol. 67, pp. 39-44.

170. R.D. O'Hara, A.G.R. Spence, and J.D. Eisenwasser: Rev. Metall. CIT, 1987, vol. 84 (2), pp. 147-234.

171. N.A. Zyuban and S.I. Zhul'ev: Metallurgist, 2000, vol. 44 (9-10), pp. 530-33.

172. A. Staronka and W. Golas: Arch. Eisenhuttenwes., 1980, vol. 51 (10), pp. 403-06.

173. P. Kazakevitch and M. Olette: Int. Conf. on Production and Application of Clean Steels, The Iron and Steel Institute, London, 1970, pp. 42-49.

174. A.W. Cramb and I. Jimbo: Iron Steelmaker, 1990, vol. 11, pp. 67-79.

175. M.D. Maheshwari and T. Mukherjee: Tisco, 1979, vol. 26 (1), pp. 9-18.

176. H. Nagayama: Tetsu-to-Hagané, 1970, vol. 56 (13), pp. 1699-715.

177. R. Datta, A. Prasad, S. Kumar, V. Bhusan, and N.S. Mishra: Steel Times Int., 1991, vol. 15 (2), pp. 40-41

178. L. Zhang, B.G. Thomas, K. Cai, L. Zhu, and J. Cui: ISSTech2003, ISS, Warrendale, PA, 2003, pp. 141-56.

179. K. Suzuki, K. Taniguchi, and T. Takenouchi: Tetsu-to-Hagané, 1975 , vol. 61 (4), pp. S96-97.

180. T. Wei and F. Oeters: Steel Res., 1992, vol. 63 (2), pp. 60-68.

181. M. Iguchi, Y. Sumida, R. Okada, and Z. Morita: Tetsu-to-Hagané, 1993, vol. 79 (5), pp. 569-75.

182. S.-H. Kim and R.J. Fruehan: Metall. Trans. B, 1987, vol. 18B, pp. 381-90.

183. R. Sankaranarayanan and R.I.L. Guthrie: Steelmaking Conf. Proc., Toronto, ISS, Warrendale, PA, 1992, vol. 75, pp. 655-64.

184. I. Manabu, S. Yutaka, O. Ryusuke, and M. Zen-Ichiro: Tetsuto-Hagané, 1993, vol. 79 (5), p. 33.
185. H.F. Marston: 69th Steelmaking Conf. Proc., ISS, Warrendale, PA, 1986, pp. 107-19.

186. J.G. Bartholomew, R.L. Harvey, and D.J. Hurtuk: 69th Steelmaking Conf. Proc., ISS, Warrendale, PA, 1986, pp. 121-27.

187. I.N. Zigalo: Steel USSR, 1989, vol. 19 (7), pp. 281-84.

188. R. Eriksson, L. Jonsson, and P.G. Jonsson: Iron Steel Inst. Jpn. Int., 2004, vol. 44 (8), pp. 1358-65.

189. L. Zhang and B.G. Thomas: "Fluid Flow and Inclusion Motion during Ingot Teeming Process-Part I: Fluid Flow," Continuous Casting Consortium Report, University of Illinois at Urbana-Champaign, Urbana, IL, 2005.

190. L. Zhang and B.G. Thomas: "Fluid Flow and Inclusion Motion during Ingot Teeming Process-Part III: Inclusion Motion," Continuous Casting Consortium Report, University of Illinois at UrbanaChampaign, Urbana, IL, 2005.

191. L. Zhang and B.G. Thomas: "Fluid Flow and Inclusion Motion during Ingot Teeming Process-Part II: Free Surface Phenomena," Continuous Casting Consortium Report, University of Illinois at UrbanaChampaign, Urbana, IL, 2005.

192. J. Outten: Foundry Management Technol., 1996, vol. 124 (8), pp. $108-10$.

193. P.F. Wieser: in Foundry Process-Their Chemistry and Physics, S. Katz and C.F. Landefeld, eds., Plenum Press, New York, NY, 1988, pp. 495-512.

194. D. Apelian and K.K. Choi: in Foundry Process-Their Chemistry and Physics, S. Katz and C.F. Landefeld, eds., Plenum Press, New York, NY, 1988, pp. 467-94.

195. A.P. Ogurtsov: Steel USSR, 1988, vol. 18, pp. 225-27.

196. A. Halvaee and J. Campbell: AFS Trans., 1998, vol. 106, pp. 35-46.

197. J.M. Harman and A.W. Cramb: Steelmaking Conf. Proc., ISS, Warrendale, PA, 1996, vol. 79, pp. 773-84.

198. Y.N. Malinochka, A.N. Kurasov, E.P. Ionts, V.A. Tishkov, and T.I. Makogonova: Steel USSR, 1990, vol. 20 (1), pp. 50-54.

199. M.M. McDonald and D.C. Ludwigson: ASTM J. Test. Eval., 1983, vol. 11 (3), pp. 165-73.

200. P.W. Wright: Met. Forum, 1979, vol. 2 (2), pp. 82-86.

201. N.N. Tripathi, M. Nzotta, A. Sandberg, and S. Du: Ironmaking and Steelmaking, 2004, vol. 31 (3), pp. 235-40.

202. N.N. Tripathi, M. Nzotta, A. Sandberg, and S. Du: Steel Grips, 2004, vol. 2 (1), pp. 40-47.

203. S. Du, A. Sandberg, and N. Tripathi: ICS 2005-3rd Int. Congr. on the Science and Technology of Steelmaking, AIST, Warrendale, PA, 2005, pp. 649-60.

204. L. Ferro, J. Petroni, D. Dalmaso, J. Madias, and C. Cicutti: Steelmaking Conf. Proc., ISS, Warrendale, PA, 1996, vol. 79, pp. 497-502.

205. T. Sjoqvist, S. Jung, P. Jonsson, and M. Andreasson: Ironmaking and Steelmaking, 2000, vol. 27 (5), pp. 373-80.

206. K. Larsen and R.J. Fruehan: Iron Steelmaker, 1991, vol. 12, pp. $125-$ 32.

207. K. Takachio and T. Nonomura: Iron Steel Inst. Jpn. Int., 1996, vol. 36 (Suppl.), pp. S85-88.

208. H. Tozawa, Y. Kato, K. Sorimachi, and T. Nakanishi: Iron Steel Inst Jpn. Int., 1999, vol. 39 (5), pp. 426-34.

209. Y. Miki and B.G. Thomas: Metall. Mater. Trans. B, 1999, vol. 30B, pp. 639-54.

210. R.B. Snow and J.A. Shea: J. Am. Ceram. Soc., 1949, vol. 32 (6), pp 187-94.

211. G.C. Duderstadt, R.K. Iyengar, and J.M. Matesa: AIME Proc. Electric Furnace Conf., 1967, pp. 61-66.

212. J.W. Farrell and D.C. Hilty: AIME Proc. Electric Furnace Conf., 1971, pp. 31-46.

213. K. Schwerdtfeger and H. Schrewe: AIME Proc. Electric Furnace Conf., 1970, pp. 95-104.

214. E. Steinmetz, H. Lindborg, W. Morsdorf, and D. Hammerschmid: Arch. Eisenhuttenwes., 1977, vol. 48 (11), pp. 569-74.

215. S.K. Saxena, H. Sandberg, T. Waldenstrom, A. Persson, and S. Steensen: Scand. J. Metall., 1978, vol. 7, pp. 126-33.

216. S. Dawson: 73rd Steelmaking Conf. Proc., Detroit, MI, Mar. 25-28, 1990, ISS, Warrendale, PA, 1990, vol. 73, pp. 15-31.

217. Y. Fukuda, Y. Ueshima, and S. Mizoguchi: Iron Steel Inst. Jpn. Int., 1992, vol. 32, pp. 164-68.

218. W. Tiekink and A. Pieters: 77th Steelmaking Conference Proceeding, vol. 77, ISS, Warrendale, PA, 1994, pp. 423-27

219. K. Ichikawa: Taikabutsu Overseas, 1994, vol. 14 (2), pp. 52-53. 
220. F. Fuhr, C. Cicutti, G. Walter, and G. Torga: ISSTech2003 Conf. Proc., ISS, Warrendale, PA, 2003, pp. 165-75.

221. F.L. Kemeny: McLean Symp. Proc., Toronto, Mar. 22-25, 1998, ISS, Warrendale, PA, 1998, pp. 103-10.

222. B.G. Thomas and H. Bai: 78th Steelmaking Conf. Proc., ISS, Warrendale, PA, 2001, pp. 895-912.

223. M.C. Schneider and C. Beckermann: Metall. Mater. Trans. A, 1995, vol. 26A, pp. 2373-88.

224. B.G. Thomas: in Continuous Casting of Steel, O. Yu, ed., Marcel Dekker, New York, NY, 2000, ch. 15.

225. B.G. Thomas, R. O'Malley, T. Shi, Y. Meng, D. Creech, and D. Stone: Modeling of Casting, Welding, and Advanced Solidification Processes, Shaker Verlag GmbH, Aachen, Germany, 2000, vol. IX, pp. 769-76.

226. J. Parkman: Master's Thesis, University of Illinois, Urbana, IL, 2000.

227. L. Zhang: Modelling Simulation Mater. Sci. Eng., 2000, vol. 8 (4), pp. $463-76$,

228. L. Zhang and S. Taniguchi: Metall. Mater. Trans. B, 2000, vol. 31B, pp. 253-66.

229. B.G. Thomas and L. Zhang: Iron Steel Inst. Jpn. Int., 2001, vol. 41 (10), pp. 1181-93.

230. Z.A. Xu and F. Mampaey: AFS Trans., 1996, vol. 104, pp. 155-66.

231. C.W. Hirt and B.D. Nichols: J. Comput. Phys., 1981, vol. 39 (1), pp. 201-25.

232. $\overline{\text { Z.A. Xu }}$ and F. Mampaey: AFS Trans., 1994, vol. 102, pp. 181-90.

233. J.J. Moore and N.A. Shah: Int. Met. Rev., 1983, vol. 28 (6), pp. 33856.

234. J. Delorme, M. Laubin, and H. Maas: in Information Symposium of Casting and Solidification of Steel, J.M. Gibb, ed., IPC Science and Technology Press Ltd., Guildford, 1977, vol. 1, pp. 214-77.

235. Y. Tsuchida, M. Nakada, Y. Kunisada, and T. Teshima: Tetsu-toHagané, 1987, vol. 73 (9), pp. 1125-32.

236. I. Ohnaka and M. Matsumoto: Tetsu-to-Hagané, 1987, vol. 73 (14), pp. 1698-705.

237. H. Yamada, T. Sakurai, T. Takenouchi, and Y. Iwanami: Tetsuto-Hagané, 1987, vol. 73 (14), pp. 1706-13.

238. R.D. Pehlke: in Foundry Process-Their Chemistry and Physics, S. Katz and C.F. Landefeld, eds., Plenum Press, New York, NY, 1988, pp. 427-46.

239. C. Beckermann: Fleming Symp., TMS, Warrendale, PA, 2000.

240. C.Y. Wang and C. Beckermann: Metall. Mater. Trans. A, 1993, vol. 24A, pp. 2787-802.

241. B.G. Thomas, I.V. Samarasekera, and J.K. Brimacombe: Metall. Trans. B, 1987, vol. 18B (1), pp. 131-47.

242. B.G. Thomas, I.V. Samarasekera, and J.K. Brimacombe: Modeling of Casting and Welding Processes III, S. Kou and R. Mehrabian, eds., TMS, Warrendale, PA, 1987, vol. 3, pp. 479-95.

243. B.G. Thomas, I.V. Samarasekera, and J.K. Brimacombe: Metall. Mater. Trans. B, 1987, vol. 18B (1), pp. 119-30.

244. M.C. Flemings: Iron Steel Inst. Jpn. Int., 2000, vol. 40 (9), pp. 833-41.

245. D. Deng: Iron Steel (China), 1986, vol. 21 (8), pp. 37-43.

246. S.I. Zhul'ev and N.A. Zyuban: Metallurgist, 2001, vol. 45 (11-12), pp. $484-89$
247. V.A. Tyurin, V.V. Romanenko, and V.P. Romanenko: Metallurgist, 2001, vol. 45 (9-10), pp. 419-22.

248. T.I.S. Asano, M. Funasaki, T. Takenouchi, and H. Yamata: Tetsuto-Hagané, 1995, vol. 81 (5), pp. T16-18.

249. K. Mukai and W. Lin: Tetsu-to-Hagané, 1994, vol. 80 (7), pp. $533-$ 38.

250. K. Mukai and W. Lin: Tetsu-to-Hagané, 1994, vol. 80 (7), pp. $527-$ 32.

251. K. Mukai: Tetsu-to-Hagané, 1996, vol. 82 (1), pp. 9-14.

252. G. Wilde and J.H. Perepezko: Mater. Sci. Eng. A (Switzerland), 2000, vol. 283 (1-2), pp. 25-37.

253. Q. Yuan and B.G. Thomas: ICS 2005-3rd Int. Congr. on the Science and Technology of Steelmaking, AIST, Warrendale, PA, 2005, pp. 745-59.

254. Q. Yuan, B.G. Thomas, and S.P. Vanka: Metall. Mater. Trans. B., 2004, vol. 35B, pp. 703-14.

255. Z. Chen, J. Liu, and J. Zeng: Iron Steel (China), 1983, vol. 18 (3), pp. 43-49.

256. X. Zhu, W. Liu, Y. Ding, J. Su, J. Zhou, M. Jiang and X. Wu: Xi'an Jiaotong Daxue Xuebao (J. Xi'an Jiaotong Univ.), 1990, vol. 24 (5), pp. 71-78.

257. Q. Xu, F. Lou, and D. Luo: Iron Steel (China), 1987, vol. 22 (1), pp. 9-15.

258. Y. Wei, L. Dong, X. Liu, Z. Yang, and R. Sun: Iron Steel (China), 1986, vol. 21 (9), pp. 18-22.

259. L. Dong, X. Liu, and Y. Wei: J. Beijing Univ. Iron Steel Technol., 1986, no. 1, pp. 23-32.

260. Z. Liu and K. Cai: Iron Steel, 2000, vol. 35 (2), pp. 64-69 (in Chinese).

261. A.W. Cramb: in Impurities in Engineered Materials: Impact, Reliability and Control, C.L. Briant, ed., Marcel Dekker Inc., New York, NY, 1999, pp. 49-89.

262. K. Ogawa: Nishiyama Memorial Seminar, Iron and Steel Institute of Japan, Tokyo, 1992, vols. 143-144, pp. 137-66.

263. H. Gao: Steelmaking, 2000, vol. 16 (2), pp. 38-43 (in Chinese).

264. H. Lachmund, B. Prothmann, D. Huin, H.S. Raymond, and H. Gaye: La Rev. Metall.- CIT, 1998, vol. 95 (4), pp. 487-99.

265. Mori: Tetsu-to-Hagané, 1965, vol. 51, p. 1930.

266. G.B.V.D. Graaf, H.E.A.V.D. Akker, and L.L. Katgerman: Metall. Mater. Trans. B, 2001, vol. 32B, pp. 69-78.

267. C.P. Hong, S.Y. Lee, and K. Song: Iron Steel Inst. Jpn. Int., 2001, vol. $41(9)$, pp. 999-1005.

268. H.J. Lin: AFS Trans., 1999, pp. 777-82.

269. H.Y. Yuan, H.T. Lin, and G.X. Sun: AFS Trans., 1997, vol. 105, pp. 723-932.

270. X. Xue, S.F. Hansen, and P.N. Hansen: AFS Trans., 1993, vol. 101, pp. $549-58$

271. X. Xue, S.F. Hansen, and P.N. Hansen: AFS Trans., 1993, vol. 101, pp. 199-209.

272. S.H. Jong and W.S. Hwang: AFS Trans., 1991, vol. 99, pp. 69-75

273. S. Mishima and J. Szekely: Iron Steel Inst. Jpn. Int., 1989, vol. 29 (4), pp. 324-32.

274. P.A. Davidson, X. He, and A.J. Lowe: Mater. Sci. Technol., 2000, vol. 16 (6), pp. 699-711. 